Linköping University Medical Dissertations No. 1499

\title{
Heart failure -
}

\section{biomarker effect and}

\section{influence on quality of life.}

\author{
Patric Karlström
}

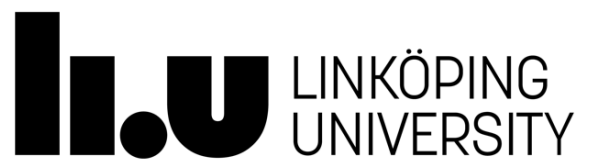

Division of Cardiovascular Medicine

Department of Medical and Health Sciences

Faculty of Medicine and Health Sciences,

Linköping University,

SE-581 83 Linköping, Sweden

Linköping 2016 
(P)Patric Karlström, 2016

Cover/picture/Illustration/Design: Martin Pettersson

Published article has been reprinted with the permission of the copyright holder.

Printed in Sweden by LiU-Tryck, Linköping, Sweden, 2016

ISBN: 978-91-7685-869-1

ISSN: 0345-0082 
"If there ever comes a day when we can't be together, keep me in your heart. I'll stay there forever"

Winnie the Pooh by A.A. Milne

Till

Ingrid, Linnéa, Albin och Klara 
Page 4 


\section{CONTENTS}

ABSTRACT.

Heart failure...............................................................................21

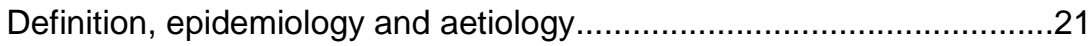

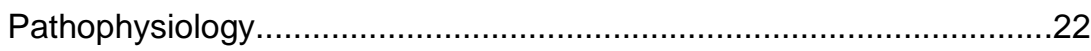

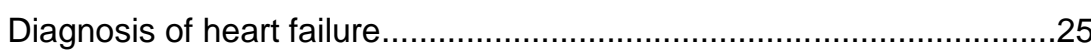

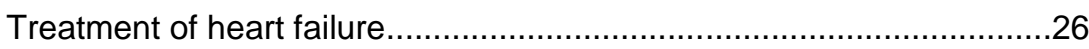

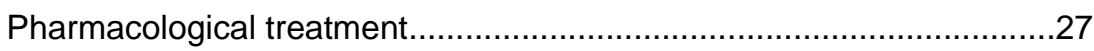

Non-pharmacologic intervention........................................................31

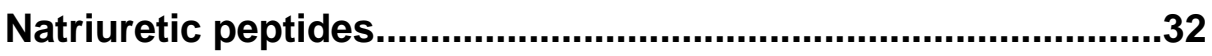

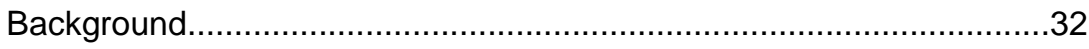

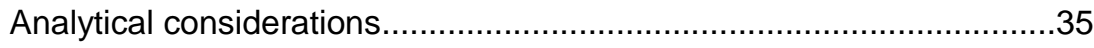

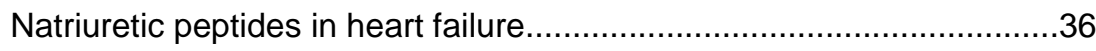


Natriuretic peptides and heart failure treatment

Natriuretic peptides for guiding patients with heart failure.

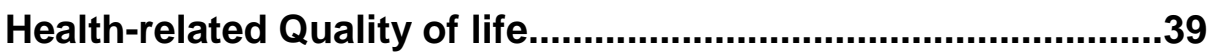

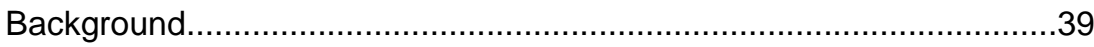

Health-related quality of life in patients with heart failure........................40

The importance of evaluating health-related quality of life......................42

Measurement and evaluation of health-related quality of life...................42

AIMS OF THE THESIS...................................................................45

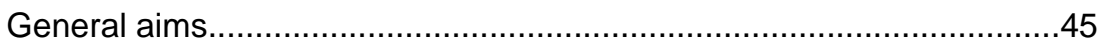

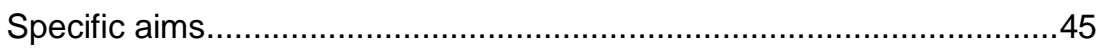

MATERIAL AND METHODS...................................................................47

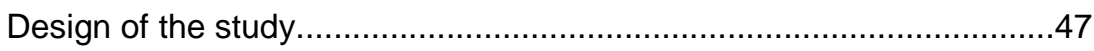

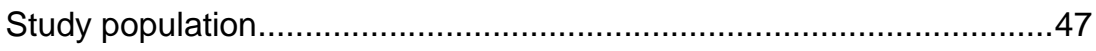

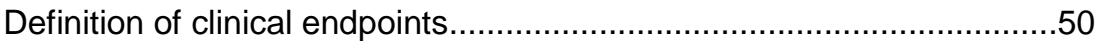

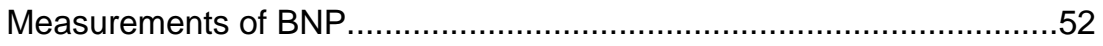

Health-related Quality of Life measurements......................................52

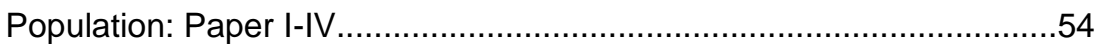

Methods: Paper I-IV .....................................................................

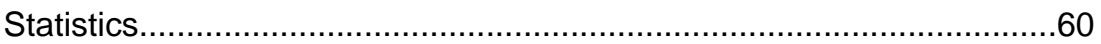

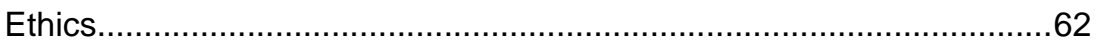

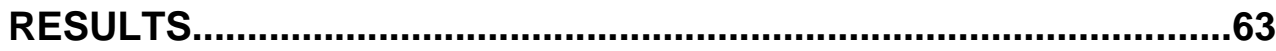

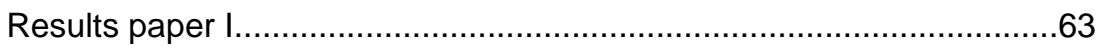


Results paper II .69

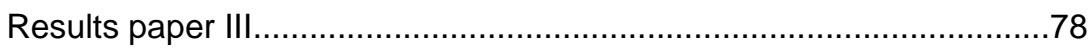

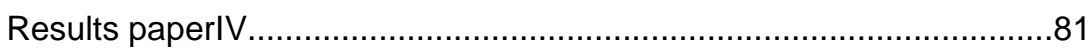

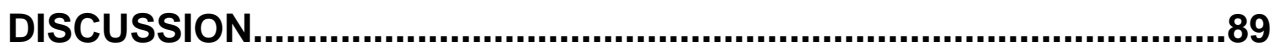

NP-guided treatment in heart failure................................................ 89

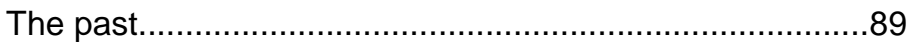

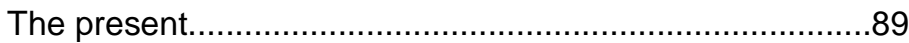

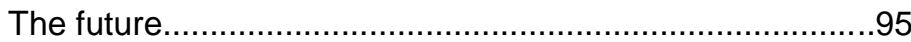

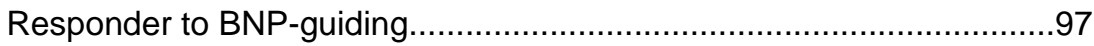

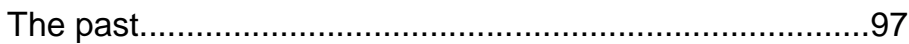

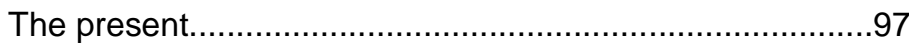

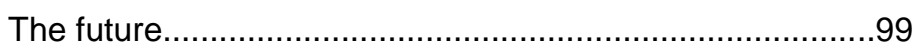

BNP-guiding and Health-related quality of life.................................100

The past....................................................................100

The present..............................................................100

The future ..................................................................103

METHODOLOGICAL CONSIDEARTIONS.........................................103

ETHICAL CONSIDERATIONS..........................................................105

CLINICAL IMPLICATIONS..............................................................105

FUTURE RESEARCH.................................................................106 


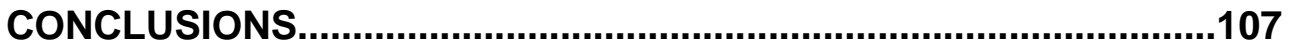

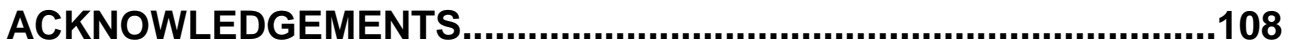

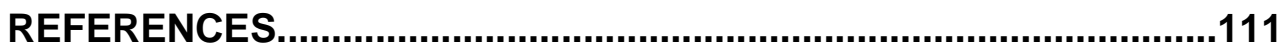

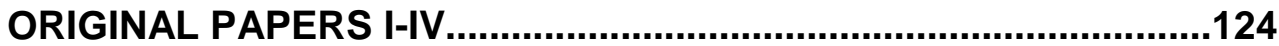




\section{ABSTRACT}

Background and aims: Heart failure (HF) is a life threatening condition and optimal handling is necessary to reduce risk of therapy failure. The aims of this thesis were: (Paper I) to examine whether BNP (B-type natriuretic peptide)-guided HF treatment improves morbidity and mortality when compared with HF therapy implemented by a treating physician at sites experienced in managing patients with HF according to guidelines; (Paper II) to investigate how to define a responder regarding optimal cutoff level of BNP to predict death, need for hospitalisation, and worsening HF and to determine the optimal time to apply the chosen cut-off value; (Paper III) to evaluate how Health-Related Quality of Life (HR-QoL) is influenced by natriuretic peptide guiding and to study how HR-QoL is affected in responders compared to nonresponders; (Paper IV) to evaluate the impact of patient age on clinical outcomes, and to evaluate the impact of duration of the HF disease on outcomes and the impact of age and HF duration on BNP concentration.

Methods: A randomized, parallel group, multi-centre study was undertaken on 279 patients with HF and who had experienced an episode of worsening HF with increased BNP concentration. The control group ( $n=132)$ was treated according to HF guidelines and in the BNP-guided group $(n=147)$ the HF treatment algorithm goal was to reduce BNP concentration to $<150 \mathrm{ng} / \mathrm{L}$ in patients $<75$ years and $<300 \mathrm{ng} / \mathrm{L}$ in patients $>75$ years (Paper I), and to define the optimal percentage decrease in BNP and at what point during the follow-up to apply the definition (Paper II). To compare the BNP-guided group with the conventional HF treated group (Paper I), and responders and non-responders (Paper II) regarding HR-QoL measured with Short Form 36 (SF-36) at study start and at study end (Paper III) and to evaluate if 
age or HF duration influenced the HF outcomes and the influence of BNP on age and HF duration (Paper IV).

Results: The primary outcome (mortality, hospitalisation and worsening HF) was not improved by BNP-guided HF treatment compared to conventional HF treatment or in any of the secondary outcome variables (Paper I). Applying a BNP decrease of at least 40 percent in week 16 (compared to study start) and/or a BNP $<300 \mathrm{ng} / \mathrm{L}$ demonstrated the best risk reduction for cardiovascular mortality, by 78 percent and 89 percent respectively for HF mortality (Paper II). The HR-QoL improved in four domains in the BNP-guided group and in the control group in six of eight domains; however there were no significant differences between the groups (Paper III). For responders the within group analysis showed improvement in four domains compared to the non-responders that improved in one domain; however there were no significant differences between the two groups. There were improvements in HRQoL in all four groups (Paper III). Age did not influence outcome but HF duration did. HF duration was divided into three groups: HF duration less than 1 year (group 1), 15 years (group 2) and $>5$ years (group 3). A 1.65-fold increased risk could be demonstrated in those with HF duration of more than five years compared to patients with short HF duration. The BNP concentration was increased with increased age, and there was a better response regarding BNP decrease in NP-guiding in patients with short HF duration, independent of age (Paper IV).

Conclusions: There were no significant differences between BNP-guided HF treatment group and the group with conventional HF treatment as regards mortality, hospitalisation or HR-QoL. The responders to HF treatment showed a significantly better outcome in mortality and hospitalisation compared to non-responders but no 
significant differences in HR-QoL. The duration of HF might be an important factor to consider in HF treatment by BNP-guiding in the future.

Keywords: Heart failure, Biomarker, B-type natriuretic peptide, Heart failure treatment, B-type natriuretic peptide guided heart failure treatment, Responders, Health-related quality of life, Heart failure duration, Outcomes. 
Page 12 


\section{LIST OF PAPERS}

This thesis is based on the following papers, which will be referred to by their Roman numerals.

I. Brain natriuretic peptide-guided treatment does not improve morbidity and mortality in extensively treated patients with chronic heart failure: responders to treatment have a significantly better outcome. Karlström Patric, Alehagen Urban, Boman Kurt, Dahlström Ulf. European Journal of Heart Failure (2011) 13, 1096-1103

II. Responder to BNP-guided treatment in heart failure. The process of defining a responder.

Karlström Patric, Dahlström Ulf, Boman Kurt, Alehagen Urban.

Scandinavian Cardiovascular Journal: SCJ [2015:1-27].

III. Can BNP-guided therapy improve health-related quality of life, and do responders to BNP-guided heart failure treatment have improved healthrelated quality of life? Results from the UPSTEP study.

Patric Karlström, Peter Johansson, Ulf Dahlström, Kurt Boman’ Urban Alehagen.

Submitted for publ.

IV. Time since heart failure diagnosis influences outcomes more than age when handling heart failure patients

Results from the UPSTEP study.

Patric Karlström, Peter Johansson, Ulf Dahlström, Kurt Boman, Urban Alehagen.

Submitted for publ. 


\section{POPULÄRVETENSKAPLIG \\ SAMMANFATTNING}

Vid hjärtsvikt är hjärtats pumpförmåga nedsatt. Vanliga symtom är trötthet, andfåddhet och bensvullnad. Hjärtsvikt är en vanlig sjukdom och bland personer över 80 år har upp till tio procent symtomgivande hjärtsvikt. Varje år får cirka 30000 patienter diagnosen hjärtsvikt och omkring 200000 personer har diagnosen hjärtsvikt i Sverige. Medelåldern vid diagnos är 75 år. De två vanligaste orsakerna till hjärtsvikt är tidigare hjärtinfarkt och högt blodtryck. Hjärtsvikt har en hög dödlighet och sjuklighet och är förknippad med sämre livskvalitet.

Om symptom, läkarundersökning och blodprover inger misstanke om hjärtsvikt kan diagnosen oftast fastställas med ett ultraljud av hjärtat. Ett av blodproverna är BNP eller NT-proBNP, som är ett hormon som hjärtats muskelceller utsöndrar när hjärtat inte mår bra, till exempel vid hjärtsvikt. Höga värden av BNP och NT-proBNP innebär en ökad risk för död och sjukhusinläggning. BNP och NT-proBNP sjunker av hjärtsviktsmedicinering. Medicineringen vid hjärtsvikt leder till en bättre överlevnad, mindre symptom och en bättre livskvalitet.

Syftet med avhandlingen var att utvärdera om hjärtsviktsbehandling styrd med hjälp av BNP gav en förbättrad överlevnad jämfört med hjärtsviktsbehandling styrd av symptom och kliniska tecken. Vi undersökte även hur man skulle definiera de som svarar på en BNP-styrd hjärtsviktsbehandling ("responders") på bästa sätt i tid och vilken förändring i BNP-värde som gav bästa definitionen av detta. Livskvalitet analyserades hos patienterna som erhöll BNP-styrd läkemedelsbehandling och de jämfördes med de som erhöll läkemedelsbehandling som styrdes av symptom och 
kliniska tecken. Vi utvärderade livskvalitet hos responders och de som inte var responders. Slutligen granskade vi om hur länge man haft sin hjärtsvikt påverkade överlevnad och sjukhusinläggningar. Ålderns påverkan på överlevnad och sjukhusinläggningar undersöktes; samt hur BNP påverkades av åldern

I vår underökning gav hjärtsviktsbehandling styrd med hjälp av BNP-värdet ingen förbättrad överlevnad eller färre sjukhusinläggningar än hjärtsviktbehandling styrd av symptom och kliniska tecken. En av orsakerna till detta var att båda grupperna sköttes på hjärtsviktsmottagningar och båda grupper erhöll en bra medicinsk behandling enligt gällande riktlinjer. Däremot hade responders, de patienter som svarade med sjunkande BNP värden på minst 40 procent (jämfört med BNP värdet vid studie start), eller ett BNP mindre än 300 ng/l i vecka 16, en förbättrad överlevnad och färre sjukhusinläggningar jämfört med de som inte var responders. Det är viktigt att definiera de patienter som inte är responders och utvärdera om det finns något ytterligare att erbjuda dessa patienter för att minska risken för förvärrad sjuklighet och död.

Det var ingen skillnad i livskvalitet mellan BNP-styrd hjärtsviktsmedicinering och hjärtsviktsmedicinering styrd av symptom och kliniska tecken. Däremot förbättrades livskvaliteten signifikant i fyra av åtta domäner i BNP-styrd grupp och i den vanliga behandlingsgruppen i sex av åtta domäner. Responders förbättrade sin livskvalitet signifikant i fyra domäner och icke-responders i en domän, däremot var det ingen signifikant skillnad mellan grupperna

Slutligen undersöktes om hur länge man haft sin hjärtsvikt påverkade risken för sjukhusinläggningar och död. Sammantaget visade det att om man haft hjärtsvikt mindre än ett år hade man mindre risk för hjärtsviktsrelaterad död eller 
sjukhusinläggning än om man haft hjärtsvikt i mer än fem år. Däremot påverkade åldern inte risken för död i hjärtsvikt eller sjukhusinläggning på grund av hjärtsvikt i vår utvärdering. Vi såg även att ålder påverkade BNP och att BNP-värdet steg ju längre man haft sin hjärtsvikt.

Sammanfattningsvis så förbättrade inte BNP-styrd hjärtsviktsbehandling risken för död eller sjukhusinläggning jämfört med hjärtsviktsbehandling styrd av symptom eller kliniska tecken. Däremot fann vi att responders hade en lägre risk för död och sjukhusinläggning. Att definiera de patienter som är icke-responders på hjärtsviktsmedicinering är viktigt så att man kan intervenera. Slutligen såg vi att ålder inte var en faktor för hjärtsviktshändelse utan det var hur länge man haft sin hjärtsvikt. Ju längre man hade haft sin hjärtsvikt, desto större var risken för hjärtsviktshändelser. 


\section{ABBREVIATIONS}

aa
ACE
ACEi
AF
AHA
ARB
BATTLESCARRED
BB
BNP
BP
CHF
CI
CRT
CTR
CV
CVL
ECG
EDV
EF
eGFR
ESC
ESV
GH
Hb
HF
HF-PEF
HF-REF
HR
HR-QoL
IHD
KCCQ
LV
LVEF
MCS
MH
MLwHF
MRA
mRNA
MRpro-ADM
NP
NT-proBNP
NYHA

aa

AF

AHA

ARB

BB

BP

$\mathrm{CHF}$

$\mathrm{Cl}$

CRT

CTR

CV

CVL

EDV

EF

ESC

ESV

$\mathrm{GH}$

$\mathrm{Hb}$

HF-REF

$\mathrm{HR}$

HR-QoL

IHD

$\mathrm{KCCQ}$

LV

LVEF

MCS

$\mathrm{MH}$

MLwHF

MRA

mRNA

MRpro-ADM

NT-proBNP

NYHA amino acid

Angiotensin-Converting-Enzyme

Angiotensin-Converting-Enzyme inhibitor

Atrial Fibrillation

American Heart Association

Angiotensin Receptor Blockers

NT-proBNP-Assisted Treatment To Lessen Serial Cardiac

Re-admission and Death trial

Beta blocker

B-type natriuretic peptide

Bodily pain (SF-36)

Congestive heart failure

Confidence Interval

Cardiac resynchronisation therapy

Control group

Cardiovascular

Cerebrovascular lesion

Electrocardiography

End diastolic volume

Ejection fraction

Estimated glomerular filtration rate

European Society of Cardiology

End systolic volume

General health (SF-36)

Haemoglobulin

Heart failure

Heart Failure with Preserved Ejection Fraction

Heart Failure with Reduced Ejection Fraction

Hazard ratio

Health-Related Quality of Life

Ischemic heart disease

Kansas City Cardiomyopathy Questionnaire

Left ventricular

Left ventricular ejection fraction

Mental component score (SF-36)

Mental health (SF-36)

Minnesota Living with Heart Failure

Mineralocorticoid receptor antagonist

Messenger ribonucleic acid

mid-regional pro-adrenomedullin

Natriuretic peptide

$\mathrm{N}$-terminal pro B-type natriuretic peptide

New York Heart Association Classification 


$\begin{array}{ll}\text { PARADIGM-HF } & \begin{array}{l}\text { Prospective comparison of Angiotensin Receptor Neprilysin } \\ \text { inhibitors with Angiotensin-converting-enzyme inhibitors } \\ \text { to Determine Impact on Global Mortality and morbidity } \\ \text { in Heart Failure }\end{array} \\ \text { PCS } & \text { Physical component score (SF-36) } \\ \text { PF } & \text { Physical functioning (SF-36) } \\ \text { PRIDE } & \text { The N-terminal Pro-BNP Investigation of Dyspnea in the } \\ & \text { Emergency department } \\ \text { PRIMA } & \text { Can Pro-brain-natriuretic peptide-guided therapy of chronic } \\ & \text { heart failure Improve heart fAilure morbidity and mortality } \\ \text { PROBE } & \text { Prospective, randomized, open, blinded evaluation } \\ \text { PROTECT } & \text { Prospective, Randomized ProBNP Outpatient Tailored } \\ & \text { Chronic Heart Failure Therapy } \\ \text { QoL } & \text { Quality of Life } \\ \text { RAAS } & \text { Renin-angiotensin-aldosterone system } \\ \text { RE } & \text { Role limitations due to emotional health problems (SF-36) } \\ \text { RP } & \text { Role limitations due to physical health problems (SF-36) } \\ \text { SD } & \text { Standard deviation } \\ \text { SF } & \text { Social functioning (SF-36) } \\ \text { SF-12 } & \text { Short Form 12 } \\ \text { SF-36 } & \text { Short Form 36 } \\ \text { SIGNAL-HF } & \text { Swedish Intervention study-Guidelines and NT-proBNP } \\ & \text { AnaLysis in Heart Failure } \\ \text { STARBRITE } & \text { The Strategies for Tailoring Advanced Heart Failure } \\ \text { STARS-BNP } & \text { Regimes in the Outpatient Setting } \\ \text { TIME-CHF } & \text { Systolic Heart Failure Treatment Supported by BNP } \\ & \text { The Trial of Intensified vs. Standard Medical Therapy in } \\ \text { UPSTEP } & \text { Elderly Patients With Congestive Heart Failure } \\ \text { Val-HeFT } & \text { Use of PeptideS in Tailoring hEart failureProject } \\ \text { VT } & \text { The Valsartan Heart Failure Trial } \\ \text { WHO } & \text { Vitality (SF-36) } \\ & \text { World Health Organisation }\end{array}$




\section{INTRODUCTION}

\section{A brief history of heart failure in the past}

"His heart is over flooded...." was the term for fluid overload or congestion related to sickness of the heart. It is one of the terms with which congestive heart failure (CHF) was described in the Ebers papyrus written in $1550 \mathrm{BC}$, during the reign of Amenhotep III, Pharaoh of the Eighteenth Dynasty, according to Saba et al. [1]. In a review of heart failure (HF) by Katz [2] he describes the Hippocratic Corpus, which describes rales already in the 4th century BC. Then Katz takes us through the history of HF via Galen who lived in the Roman Empire, who saw the heart distributing heat in an ebb and flow. This was believed until 1628 when William Harvey described the circulation in animals as, "pulsatile movement", and created the basis for understanding the circulation. The use of Foxglove (Digitalis purpurea) was described by William Withering, an English physician and botanist. He had learned from a countrywoman that tea made from leaves of the foxglove was good for dropsy. This information was published in An Account of the Foxglove in 1785. In 1918 Frank Starling added another cornerstone to our knowledge of HF, the Starling curve. Katz points out that the causes of HF have changed over the centuries. At the beginning of the $20^{\text {th }}$ century 51 percent were caused by rheumatic valve disease, 11 percent by bacterial endocarditis and nine percent by cardiovascular (CV) syphilis. There was little progress in treating patients with dropsy (oedema), but in 1920 when Saxl and Heilig gave organic mercurial to kill spirochetes in patients with syphilitic aorta valves they saw massive diuresis. In a case report by Ross et al. they reported massive diuresis and symptom relief following the use of mercuhydrin [3]. However, the mercurial agents were associated with substantial toxicity, and until the 1950s there 
was no effective treatment of fluid overload in HF patients. The first diuretics, the thiazide diuretics, were introduced 1958 [4], and diuretics are nowadays used to relieve symptoms of HF.

We now come to the era of evidence-based medicine [5], and the modern HF treatments are emerging. In the 1980s and early 1990s, it was demonstrated that angiotensin -converting-enzyme inhibitor (ACEi) were associated with improvement in the clinical outcomes for HF patients [6]. Then followed the introduction of the modern HF treatments; beta blocker, angiotensin receptor blockade, mineralocorticoid receptor antagonist, Cardiac Resynchronisation Therapy (CRT), with or without defibrillation therapy, left ventricular assist device and heart transplantation [7]. Regarding the diagnostic possibilities, echocardiography has emerged as an important tool to evaluate HF patients, along with natriuretic peptides (NP). Despite this improvement in HF medication, the mortality rate is high [8]. Can tailored $\mathrm{HF}$ treatment with the help of biochemical measures such as NP lead to a better outcome for HF patients? 


\section{BACKGROUND}

\section{Heart Failure}

\section{Definition, epidemiology and aetiology}

$\mathrm{HF}$ is a complex clinical syndrome, characterized by systemic perfusion that is inadequate to meet the body's metabolic demands caused by an impaired cardiac pump function [7]. HF is a leading cause of mortality, morbidity, hospitalisation, and disability [9] and the patient's perceived health-related quality of life (HR-QoL) is impaired [10]. However, despite recent improvements in pharmacological treatments, the prognosis is poor, with an estimated five-year survival of approximately 50 percent [11]. The cost for HF has been estimated to be approximately two percent of the national health care budget in developed countries $[12,13]$. The total annual cost for patients with HF in Sweden 2005 was in the range of SEK 5.0-6.7 billion. Approximately 50 percent of the costs are related to hospitalisation and the primary healthcare accounts for 20 percent, according to Agvall et al. [14]. The re-admission rates are 24 percent and there is a 14 percent mortality rate within the first three months after a previous HF hospitalization [15]. At the diagnosis of HF, higher costs are observed for HF patients and then the costs increase in the months immediately before death in those surviving more than 12 months after HF diagnosis [16].

There was no change in HF prevalence in Sweden from 2006 to 2010, and the estimated prevalence of $\mathrm{HF}$ in Sweden was $2.2 \%$, whereas the incidence and mortality decreased during the same period [11]. The prevalence of $\mathrm{HF}$ is approximately $1 \%$ in persons of 50 years of age, increasing progressively with age to 
around $10 \%$ when patients are 80 years old [17]. By looking into gender differences, HF affects approximately $10 \%$ of men and $8 \%$ of women over the age of 60 years and the prevalence rises with age [18].

In the Western world, coronary artery diseases either alone or in combination with hypertension are the leading causes of HF [19-23]. Valvular heart disease, arrhythmias, cardiomyopathies, chemotherapy, previous viral/bacterial infections and alcohol abuse cause 15-20 percent of HF [24, 25]. In earlier longitudinal epidemiological studies; (the Framingham data and 1913 years men in Gothenburg), the leading cause of HF was hypertension [26, 27]; however this has changed over the decades to become ischemic heart disease $[15,28]$.

\section{Pathophysiology}

$\mathrm{HF}$ is a progressive and complex syndrome that can be caused by any structural or functional cardiac disorder that impairs the ventricles in their ability to fill with and eject blood.

\section{Remodelling}

The definition of cardiac remodelling is an alteration in structure (shape, mass, dimensions) of the heart in response to cardiac injury or haemodynamic influence in association with neurohormonal activation [29]. Remodelling can be physiological or pathological as a response to cardiac injury (myocardial infarction, myocarditis) or with pressure overload (aortic stenos, hypertension), or with volume overload (valvular regurgitation) [30,31]. Remodelling is associated with different cellular 
changes including myofibroblast proliferation, myocytes hypertrophy, interstitial fibrosis and myocytes apoptosis [32-34]. The response to injury and stress after a myocardial infarction is that the injured area expands, and there is regional dilation and a thinning of the infarct zone. The myocardial infarct zone scarifies and remodels the wall, and the geometry of the ventricle changes. The ventricle walls get thinner and become less elliptical and more spherical $[35,36]$. The remodelling is pathophysiologically important in HF and it has been observed that ACEi and beta blockers (BB) can slow and sometimes reverse cardiac remodelling [37-41].

\section{Neurohormonal activation}

The renin-angiotensin-aldosterone system (RAAS) is a signalling pathway that regulates fluid, electrolyte balance and the systemic blood pressure [42], (Figure 1).

The activation of the RAAS system can be by a reduction in blood pressure in the arterioles in the glomerulus or a decrease in the sodium concentration in the distal tubule, which induces renin release [43]. Angiotensinogen is released into the circulation by the liver, renin catalyses cleavage of angiotensinogen to angiotensin I, which is cleaved by angiotensin-converting-enzyme (ACE) to angiotensin II [44]. Angiotensin II has three effects on the heart; an inotropic effect, chronotropy [45] and hypertrophy of cardiac myocytes [46]. Angiotensin II constricts both the afferent and efferent arterioles, but mainly increases efferent resistance. Angiotensin II increases the permeability of the coronary arteries, allowing growth factors into the myocardial interstitium [47]. These effects can be reduced by ACEi and BB [37-41].

Aldosterone is a steroid hormone synthesized in and mainly secreted from the adrenal cortex and also locally in the failing heart and it effects the mineralocorticoid 
receptor, expressed in many tissues and in the heart [48]. Aldosterone regulates the blood pressure mainly by acting in the distal tubule by increasing the re-absorption of ions and water. The direct effect of aldosterone on the heart may include proarrhytmia [49], hypertrophy and fibrosis $[50,51]$ and the transition from hypertrophy to HF due to pressure overload [52].

\section{Figure 1.}

The RAAS system regulates blood pressure and fluid balance. Angiotensinogen is released into the circulation by the liver; renin catalyses cleavage of angiotensinogen to angiotensin I, which is cleaved by angiotensin-converting-enzyme (ACE) to angiotensin II, angiotensin-converting-enzyme inhibitor (ACEi) inhibits this step. Angiotensin receptor blocker (ARB) blocks the activation of angiotensin II on the angiotensin 1 receptor ( $A T_{1}$ receptor). Mineralocorticoid receptor antagonist (MRA) affects the mineralocorticoid receptor. Antagonism of these receptors inhibits sodium resorption in the kidneys. This interferes with sodium/potassium exchange, reducing urinary potassium excretion and weakly increasing water excretion (diuresis).

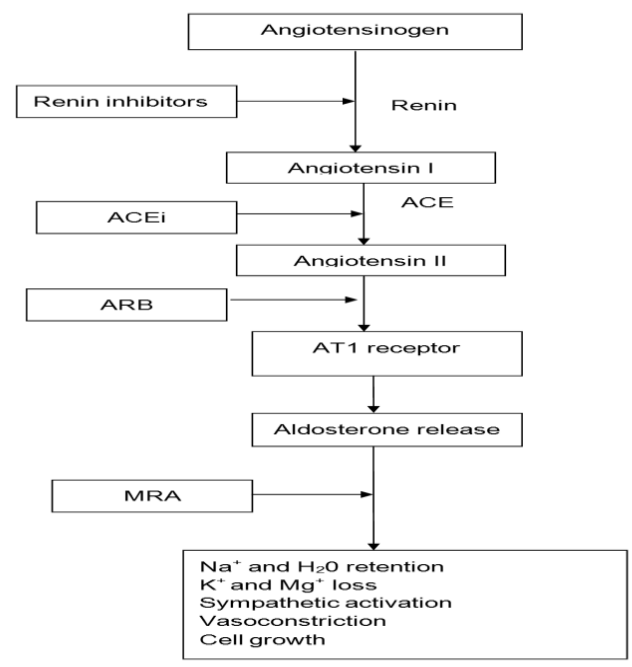




\section{Diagnosis of heart failure}

$\mathrm{HF}$ can be defined as a complex syndrome that results from any structural or functional abnormality of the ventricular filling or ejection of blood [8]. The symptoms of $\mathrm{HF}$ can vary from patient to patient; however, the main symptoms are breathlessness, tiredness and peripheral oedema. The signs and symptoms are not specific to HF and the diagnosis can therefore be difficult especially in early stages $[53,54]$. Therefore, the diagnosis of $\mathrm{HF}$ is based on the combination of signs and symptoms, combined with N-terminal pro B-type natriuretic peptide (NT-proBNP)/Btype natriuretic peptide (BNP) and objective verification of impaired cardiac function with echocardiography, cardiac magnetic resonance or multi-detector computed tomography, cardiac catheterisation, single photon emission computed tomography or positron emission tomography $[7,55,56]$. When $\mathrm{HF}$ progresses, new signs and symptoms occur such as elevated jugular venous pressure, third heart sound, nocturnal cough, weight gain, pulmonary crepitations and cardiac murmur. Routine laboratory tests are recommended (haematological tests [haemoglobin, haematocrit, leukocytes, platelets and ferritin], sodium, potassium, creatinine/estimated glomerular filtration rate (eGFR), NTpro-BNP/BNP and thyroid-stimulating hormone, to exclude other diseases that can mimic HF [7]. The electrocardiogram gives information on previous myocardial infarction, left ventricle hypertrophy and arrhythmias $[57,58]$ and can give clues to the aetiology of HF.

To evaluate the cardiac function, echocardiography is most often used because of its cost, accuracy, availability and safety. This provides information about cardiac function, cardiac anatomy, valvular function and establishes the ejection fraction (EF) [7]. EF can be calculated by dividing the volume ejected by the heart (stroke volume=end-diastolic volume (EDV)-end systolic volume (ESV)) divided by the EDV, 
$E F=(E D V-E S V) / E D V$. The EF also gives important prognostic information [59]. The EF depends on volume, dimensions, ventricular heart rate, valvular function, preload (the pressure of the blood on the ventricles at the end of diastole), afterload (the pressure in the wall of the left ventricle during ejection) and the results are dependent on the measuring procedures. However, measurements of EF have methodological uncertainties as well as inter-observer variability $[60,61]$. As the availability of echocardiography is limited, the introduction of NP as a screening method in patients with signs and symptoms of $\mathrm{HF}$ to rule out $\mathrm{HF}$ is a valuable tool in the diagnostic approach [7].

Echocardiography is used to establish whether the patients has systolic HF (impaired contractile or pump function) or diastolic HF (impaired ventricular relaxation) and they may coexist $[8,62]$. According to ESC (European Society of Cardiology) guidelines 2012 the diagnosis of systolic HF also called Heart Failure with Reduced Ejection Fraction (HF-REF) requires three of the following conditions; symptoms and signs typical of HF and reduced EF [7]. HF-REF is defined as the clinical diagnosis of HF and EF $\leq 40$ percent [8]. In diastolic HF, also called Heart Failure with Preserved Ejection Fraction (HF-PEF) the diagnosis is more difficult to establish compared to HF-REF according to the ESC Guidelines 2012 [7], and several criteria have been proposed to define HF-PEF $[63,64]$.

\section{Treatment of heart failure}

The goals of the treatment are to relieve signs and symptoms, improve the HF patients' Quality of Life (QoL) prevent hospitalisation, and improve survival [7]. The pharmacological treatment of the HF patient is complex, with different combinations 
of pharmacological agents. Rapid deterioration of the clinical condition and side effects of the HF medication can require modification of the therapeutic approach. The combination of medical treatment with non-pharmacological interventions is important, as is the use of device therapy [7].

\section{Pharmacological treatment}

Inhibition of renin-angiotensin-aldosterone system

There are three different agents that affect the RAAS in HF treatment; ACEi, angiotensin receptor blockers (ARB) and mineralocorticoid receptor antagonists (MRA). They can be provided in various combinations with additional effects, (Figure 2).

ACEi is the first line treatment for HF with reduced left ventricular ejection fraction and is well documented. It reduces mortality, morbidity, hospitalisations, and improves QoL for patients with symptomatic HF, for patients in New York Heart Association (NYHA) class II-IV (Table 1) [6, 7, 65, 66]. ACEi inhibits the enzymatic degradation of angiotensin I to angiotensin II (Figure 1). The effect of ACEi on renal function in $\mathrm{HF}$ patients is related both to the glomerular actions of angiotensin II and to the mechanism of auto regulation of the glomerular filtration rate. Medication with ACEi has been demonstrated to decrease preload, promote natriuresis, cause vasodilatation, improve cardiac output and reduce left ventricular (LV) remodelling [67-71]. 


\section{Table 1.}

Description of New York Heart Association (NYHA) functional classification [7, 72].

\begin{tabular}{ll}
\hline NYHA class I & $\begin{array}{l}\text { No limitations of physical activity. Ordinary physical activity } \\
\text { does not cause breathlessness, fatigue or palpitations. }\end{array}$ \\
\hline NYHA class II & $\begin{array}{l}\text { Slight limitations of physical activity. Comfortable at rest, } \\
\text { but ordinary physical activity results in breathlessness, } \\
\text { fatigue or palpitations. }\end{array}$ \\
\hline NYHA class III & $\begin{array}{l}\text { Marked limitations of physical activity. Comfortable at rest } \\
\text { but less than ordinary physical activity results in } \\
\text { breathlessness, fatigue or palpitations. }\end{array}$ \\
\hline NYHA class IV & $\begin{array}{l}\text { Unable to carry on any physical activity without discomfort. } \\
\text { Symptoms at rest present. If any physical activity is } \\
\text { undertaken, discomfort is increased. }\end{array}$ \\
\hline
\end{tabular}

ARBs block the action of angiotensin II by preventing angiotensin II from binding to angiotensin II receptors (Angiotensin I receptor) (Figure 1). ARBs act by antagonizing angiotensin II-induced vasoconstriction, aldosterone release, catecholamine release, arginine vasopressin release, water intake, and hypertrophic response [73]. ARBs have been shown to reduce HF hospitalisation, cardiovascular mortality and to improve symptoms and QoL [7, 74, 75], (Figure 2).

Aldosterone stimulates ACE; this effect is blocked by MRA (Figure 1) [76]. MRA have beneficial effects on net fluid balance by promoting diuresis and natriuresis [77]. MRA have been shown to significantly reduce left ventricular hypertrophy in hypertensive patients [78]. MRA can reduce mortality and HF hospitalisation [79, 80]. MRA could be considered as an addition to ACEi and BB in patients in NYHA class II-IV (Table 1) [7], (Figure 2). 


\section{Figure 2.}

Medical treatment algorithm for patients with chronic symptomatic HF, adapted from ESC Guidelines for diagnosis and treatment of acute and chronic HF 2012 [7].

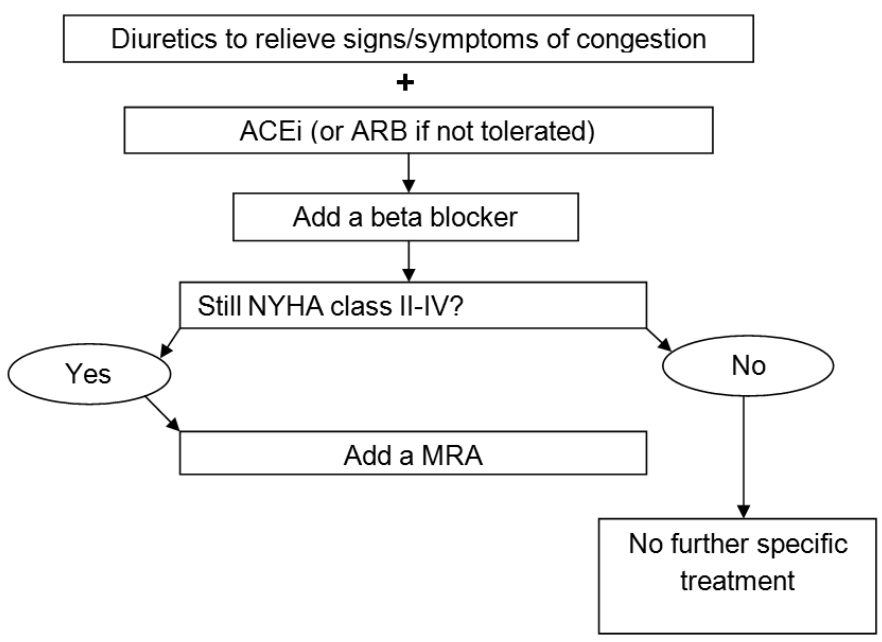

Beta blockers

Exposure to catecholamine's for a long time is harmful to the myocardium [81-83], but this effect is blocked by BB. BB reduces the levels of circulating vasoconstrictors (norepinephrine, renin, endothelin). Vasoconstrictors increase afterload and thereby promote the progress of cardiac dysfunction [84]. reduce heart rate, ventricular arrhythmias, improve the contractility $[85,86]$ and systolic blood pressure and thereby decrease myocardial oxygen demand [87]. The time course includes a reduction in EF during the first weeks of $\mathrm{BB}$ treatment, a return to initial $\mathrm{EF}$ after four weeks and finally an increase in EF [88]. A number of factors contribute to the effect of BB. BB decrease LV end-diastolic and end systolic volume and have a beneficial effect on LV remodelling $[40,41,89]$. 
In patients with HF, BB reduce mortality, hospitalisation and improves QoL [7, 90-93]. BB should be used as the basis of treatment, together with ACEi and ARBs for all patients with chronic systolic heart failure from symptoms to NYHA class II and also in patients with NYHA class I where ischemia genesis exists [7], (Figure 2). In clinical trials where patients used BB for at least three months, left ventricular ejection fraction (LVEF) increased [94]. In 1996 Gilbert et al. compared the two BBs carvedilol and metoprolol, and data was obtained from two concurrent placebo-controlled trials. BB treatment showed improvement in NYHA class, improvements in left ventricular ejection fraction, stroke volume, and stroke work compared with changes in the respective placebo groups [95].

\section{Digoxin}

Digoxin has a positive inotropic effect and decreases heart rate without an effect on blood pressure [96]. Treatment with digoxin has shown a reduction in hospitalisation due to worsening HF $[97,98]$. Digoxin can be used in patients with symptomatic HF and Atrial Fibrillation (AF) with a rapid heart rate, and in patients with sinus rhythm and LVEF $\leq 40 \%$ digoxin can be beneficial [7].

\section{Diuretics}

Diuretics are used to relieve symptoms of dyspnoea and oedema, and are recommended to patients with signs and symptoms of congestion due to salt and water retention, which results in expansion of the extracellular fluid volume [7]. The effect is exerted through reduced filling pressures and decreased fluid overload. 
Despite the wide use of loop diuretics in HF, their effect on outcome has not been evaluated in large randomized clinical trials [7]. Hasselblad et al. demonstrated that there was a strong relation between loop diuretic dose and mortality $(p=0.003)$, especially at furosemide doses $>300 \mathrm{mg} /$ day during HF hospitalisation in 395 patients [99].

\section{Non-pharmacologic intervention}

Education of the HF patient regarding symptoms, weight fluctuation, fluid and sodium intake and physical activity are important factors in patients' self-care management $[100,101]$. Follow-up visits at an HF nurse-based out-patient clinic after hospitalisation improved survival, reduced the number of events, readmissions, days in hospital and increased self-care [102]. The non-pharmacological treatment strategies demand a multidisciplinary HF team comprising a cardiologist, an HF nurse and a physiotherapist. A review by McAlister et al. showed that multidisciplinary strategies for the management of patients with $\mathrm{HF}$ reduce HF hospitalisation and also reduce mortality and all-cause hospitalisation [103]. 


\section{Natriuretic Peptides}

\section{Background}

With the introduction of natriuretic peptides it became possible to evaluate the HF patient with a blood sample. This was possible because Sudoh et al. in 1988 isolated Brain Natriuretic Peptide (BNP) from porcine brain tissue [104]. BNP is presently called B-type Natriuretic Peptide. BNP is produced by the cardiomyocytes but also from the lung, kidneys, brain and adrenal glands [105-109], (Figure 3). BNP is secreted as a response to changes in ventricular and atrium volumes resulting in increased myocardial wall tension [110,111], due to fluid overload, arrhythmias, valvular disease and pulmonary embolism [112, 113] (Figure 5). BNP produces diuresis and natriuresis through vasodilatation and smooth muscle relaxation [104, 114-116].

The BNP gene is located in chromosome 1 and produces messenger ribonucleic acid (mRNA) [117]. The mRNA is transcribed into a 134 amino acid (aa) precursor protein (pre-proBNP) [118] and the pre-proBNP is cleaved into proBNP, 108 aa prohormone [104]. The proBNP is cleaved by proteolytic enzymes into two portions, the biological active 32 aa molecule BNP and the inert 76 aa NT-proBNP. BNP and NT-pro-BNP are secreted from the cardiomyocytes $[107,119]$ in a 1:1 ratio (Figure 3 ). 


\section{Figure 3.}

Secretion of BNP and NTpro-BNP modified and adapted according to a model by Clerico [120]. The BNP gene is transcribed to BNP mRNA and cleaved to preproBNP, 134 amino acid (aa). PreproBNP is cleaved into proBNP and finally cleaved by a proteolytic enzyme into two portions and secreted into the blood as BNP (32 aa) and NT-proBNP (76 aa).

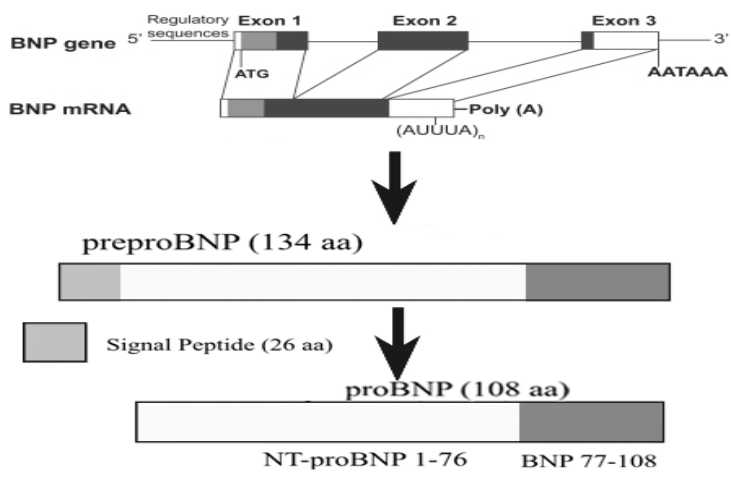

\section{Cardiomyocyte}

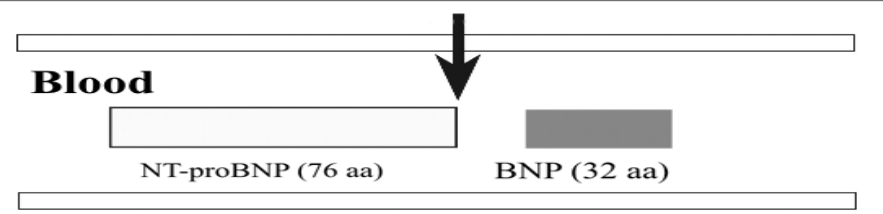

The BNP molecules bind to one of the three specific receptors for natriuretic peptides [121-123]. There are three different ways to eliminate BNP: a clearance receptor binds BNP and the BNP is degraded intracellularly $[124,125]$, degradation is caused by the enzyme neprilysin, also known as neutral endopeptidase by cleavage of BNP at two positions [126], and finally there is passive excretion and renal filtration [127]. The clearance of NTpro-BNP is mainly by renal excretion $[128,129]$ and for patients with renal insufficiency (eGFR<60 $\mathrm{ml} / \mathrm{min} / 1.7 \mathrm{~m}^{2}$ ) the cut-off levels may have to be 
raised [130]. The half-life of BNP is approximately 20 minutes [107, 131] and for NTpro-BNP it is approximately 120 minutes.

\section{Figure 4.}

The physiological effects of BNP (B-type natriuretic peptide). Cardiomyocyte stretch caused by volume/pressure overload leads to BNP release. BNP inhibits RAAS (renin-angiotensin-aldosterone system) and the sympathetic nervous system. BNP is a peripheral vasodilator and induces natriuresis and diuresis. Adapted and modified from Weber, Role of BNP and NT-proBNP in clinical routine [132].

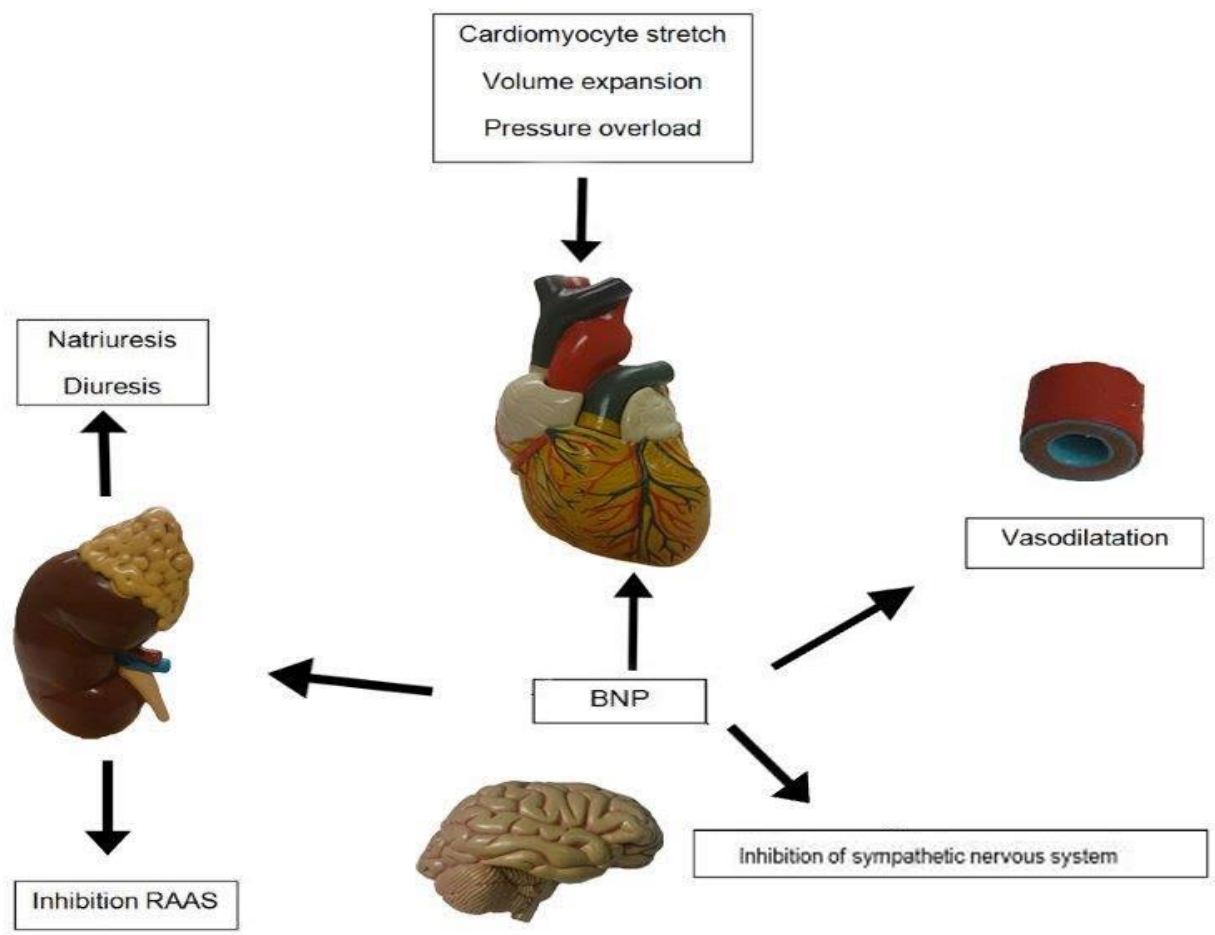




\section{Analytical considerations}

NP has been shown to be useful in the diagnosis of HF [7] (Figure 6), but as with all laboratory measurements, it must be interpreted in the context of the patient's characteristics such as age, gender and weight [133].

BNP and NT-proBNP can be measured by fully automated and commercially available assays. Points of care analysis are also available for both BNP and NTproBNP. BNP is stable in whole blood in room temperature for up to three days [134] and NTpro-BNP for three days at room temperature or longer at 4 degrees Celsius [135].

Plasma levels of BNP and NT-proBNP are lower in men compared to women, and NP levels increase with age [136]. NP levels are inversely related to body mass index and lean mass $[137,138]$. The reason for this is not fully understood but may be due to an increase of the clearance receptor in the adipocytes, leading to increased clearance of BNP [139-141]. Patients with reduced kidney function have elevated levels of NP [127, 142]. 


\section{Natriuretic peptides in heart failure}

The diagnostic role of NPs is well established (Figure 5), with different thresholds depending on acute or non-acute onset and the use of BNP or NT-proBNP [7]. In patients with stable HF there is an approximately 30 percent increase in risk of mortality, associated with an increase in BNP of $100 \mathrm{ng} / \mathrm{L}$ [143]. Berger et al. showed in 2002 that BNP level was a strong and independent predictor of sudden death in patients with CHF [144]. In the Valsartan Heart Failure Trial (Val-HeFT trial), BNP was measured at study start and during follow-up. Patients with the greatest percent decrease in BNP from baseline to four and 12 months follow-up had the lowest risk, whereas patients with the greatest percentage increase in BNP had the highest risk of morbidity and mortality [145].

\section{Figure 5.}

Algorithm for diagnosis of HF, adapted from ESC Guidelines for diagnosis and treatment of acute and chronic HF 2012 [7].

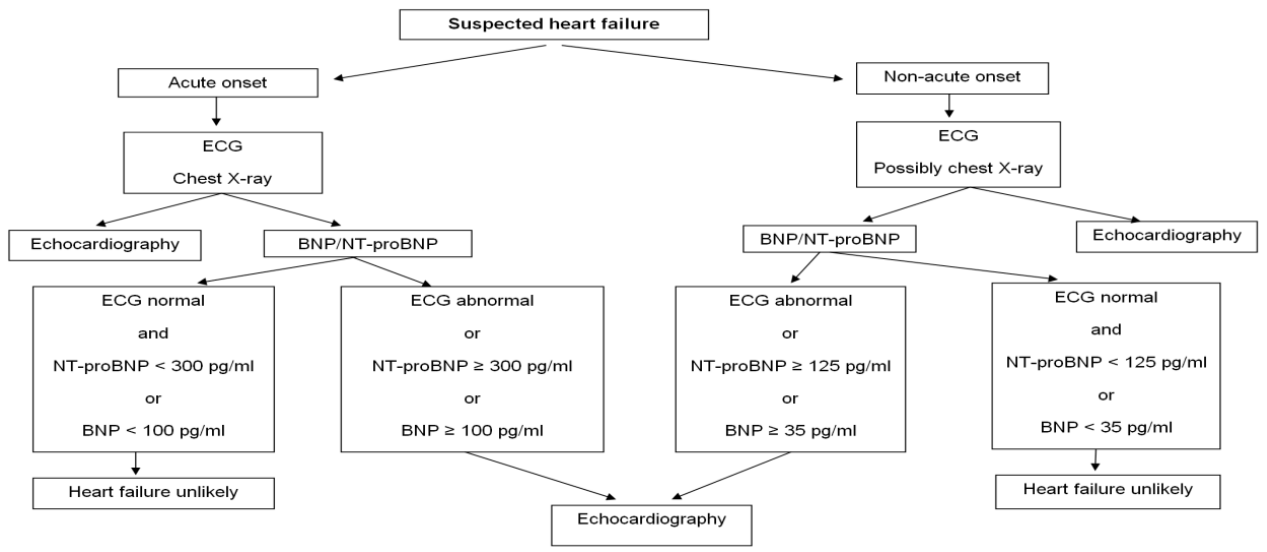

Notes: $B N P=B$-type natriuretic peptide, $E C G=$ Electrocardiography, $N T$-proBNP $=N$-terminal pro $b$ type natriuretic peptide. 
NP has a wide range of applications in patients with HF. In the Breathing Not Properly trial, BNP was used in the emergency department to identify suspected HF among patients with dyspnoea. BNP with a cut-off value at BNP>100 ng/L was superior to clinical judgment of HF in patients with dyspnoea [146], and similar finding was shown by Januzzi et al. in the N-terminal Pro-BNP Investigation of Dyspnea in the Emergency department (PRIDE-study) [147]. Another application of BNP is to predict the patients' prognosis by the use of BNP during hospitalisation. Bettencourt et al. demonstrated that a decrease during hospitalisation in NTpro-BNP of at least 30 percent from admission to discharge reduced levels of re-admission and mortality [148]. A pre-discharge BNP value $>700 \mathrm{ng} / \mathrm{L}$ gave a significant increased risk of death or re-admission compared to a BNP $<350 \mathrm{ng} / \mathrm{l}$ after an episode of hospitalisation caused by decompensated CHF [149]. A multinational study by Lassus et al. found that after an episode of hospitalisation for acutely destabilized HF, NT-proBNP levels were confirmed to add prognostic value to clinical risk factors for predicting one-year mortality [150].

\section{Natriuretic peptides and heart failure treatment}

All medical HF treatments reduce NP; ACEi and ARB lead to a reduction in BNP $[145,151]$, MRA also reduce NP concentrations in HF patients [152, 153]. BNP reacts differently to $\mathrm{BB}$ the NP concentrations increase when $\mathrm{BB}$ is introduced to the HF patient [154], but decline as the BB treatment continues [155, 156]. Digitalis reduces the BNP concentration in patients with cardiac dysfunction [157]. Diuretics reduce the plasma volume and this results in a reduced filling pressure and a reduction in NP concentration [158]. NP levels can also be reduced by CRT therapy 
[159] and combined endurance/resistance [160] as well as aerobic training [161]. Another aspect of NP in HF is that it may be useful as a help on how to tailor the patient's medical treatment.

\section{Natriuretic peptides for guiding patients with heart failure}

In a small study of 20 patients with mild to moderate HF in 1999, Murdoch et al. showed that BNP-guided treatment (titration of ACEi) gave a significant reduction in BNP in the BNP group compared to a clinical group [162]. In 2000 the hypothesis was tested in the first NT-proBNP-guided study by Troughton et al. They showed that NP-guided treatment of HF reduced the total number of cardiovascular events, and delayed the time to the first event compared with intensive clinically guided treatment [163]. However, the study enrolled few patients $(n=69)$ and the NT-proBNP value to guide to was $200 \mathrm{pmol} / \mathrm{l}$, which is approximately a NT-proBNP of $1700 \mathrm{ng} / \mathrm{L}$ (pmol//x8.457=ng/L) [132]. One may criticize this value for being high when using NTproBNP as a guiding goal. When this thesis was planned in 2003-2004, Troughton's study from 2000 was the only published data on BNP-guiding of HF treatment. Since the cost of analysing BNP is approximately 150 SEK, BNP-guiding could be used as a cheap useful tool in the handling of HF treatment. 


\section{Health-related quality of life}

\section{Background}

The concept of QoL has no universal definition [164] but can be seen as a broad multidimensional concept and reflects a variety of aspects of the patient's life [165], such as economic situation, work, religion, work, age, social-physical- and physiological health. The taxonomy that defines QoL can be divided into: global, component, focused and a combination definition [164]. The global definition defines the person's happiness or unhappiness and satisfaction or dissatisfaction. The component definitions identify certain characteristics and could contribute to the global definitions. Component definitions are usually maintenance of dignity, emotional well-being and freedom of choice. The focused definitions refer commonly to health/functional ability such as Health-related Quality of life (HR-QoL). To distinguish between QoL in a general sense the term HR-QoL is used in clinical medicine and in clinical trials to remove ambiguity.

There is today no consensus on how to define HR-QoL $[164,166]$; however, HR-QoL can be said to have its roots in the World Health Organisation (WHO) definition of health: "Health is a state of physical, social, mental well-being and not merely the absence of disease or infirmity" [167]. Based on the WHO definition, health consists of three components, namely physical, psychological and social well-being. Thus, to use QoL as a substitute for health is misleading $[164,165]$ because QoL is more than health, and when evaluating QoL from a health perspective the term HR-QoL is often more useful [168]. This is because HR-QoL is used specifically to measure 
dimensions of health and measures how diseases and symptoms affect well-being, health, and the ability to function in daily life.

\section{Health-related quality of life in patients with heart failure}

HF patients have reduced HR-QoL compared to a normative population in the community $[10,169]$ as well as when compared to patients with other chronic diseases [170] such as patients with a history of angina pectoris, previous myocardial infarction, AF, hypertension, history of chronic bronchitis, emphysema and arthritis. [10].

Figure 6 shows a model of HR-QoL in HF, indicating that there is a complex relationship between HF pathophysiology, symptoms, physical and psychological limitations and HR-QoL in HF patients. HF is a combination of signs and symptoms (i.e. dyspnoea, fatigue and oedema) which can lead to functional limitations, for example impaired exercise capacity and psychological stress such as worries or depression and social isolation, but also effects that mediate HF pathophysiology (fatigue leads to impaired exercise capacity) $[169,171,172]$. Figure 6 also shows that pathophysiologic variables, for example neurohormonal activation and ejection fraction, do not have a direct effect on patients' HR-QoL [171], and the correlation between pathophysiology variables and HR-QoL is often not strong [173, 174]. However, the HF symptoms the patients experience are caused by the pathophysiology of $\mathrm{HF}$, such as impaired cardiac function as reflected by reduced $\mathrm{EF}$ and/or NP, and thus the influence of HF pathophysiology on HF patients HR-QoL is mediated by HF symptoms [171]. With worsening HF and an increase in NYHA class there is a decrease in HR-QoL [175]. There are also other factors that influence HR- 
QoL such as personal traits (negative affectivity), lifestyle demands, culture and comorbidity [171]. Studies have shown that gender has an impact on HR-QoL; women with HF reported poorer HR-QoL compared to men with HF $[176,177]$.

HR-QoL is a personal perception and shows how the individual feels about their ordinary life and/or health [178]. Thus, HR-QoL has different meanings to different persons and also different meanings according to the area of application. In the context of medicine and clinical trials there is more interest in evaluating those aspects that are affected by disease and treatment. Thus, in HF this means that patients with the same kind of severity of $\mathrm{HF}$, reflected by EF and/or NP, can perceive and value the impact of symptoms differently and thereby also value their HR-QoL differently.

\section{Figure 6.}

Conceptual model of HR-QoL relationships between heart failure pathophysiology, symptoms, functional limitations, physiological stress and quality of life, developed and adapted from Rector [171].

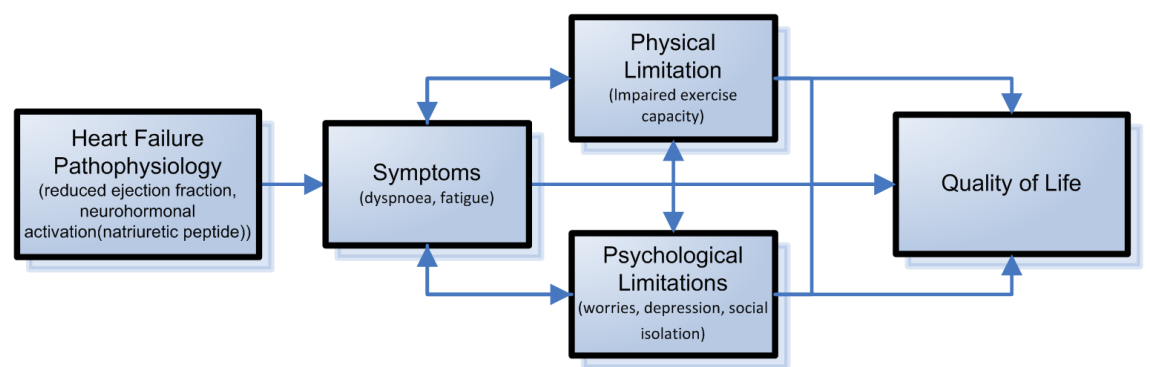




\section{The importance of evaluating health-related quality of life}

HR-QoL provides insights into treatment from the patient's perspective [179]. In a review article by Anker et al. the importance of Hr-QoL was emphasized, and it was recommended that these outcomes should be reported in all clinical CV trials, in addition to mortality and morbidity [180]. A scientific statement from the American Heart Association (AHA) concluded that patient-reported health status is an important CV health outcome and includes three domains: symptom burden, functional status and HR-QoL [181]. However, more research is needed to determine the threshold that implies clinical improvement [182], and finally HR-QoL can only be assessed in patients alive at the study end.

\section{Measurement and evaluation of health-related quality of life}

"How are you" is probably the most common question in clinical practice to explore the patient's well-being. However, medical science has by tradition focused on assessment of disease severity, morbidity and mortality. One important development in health care during the last few decades is the recognition that the patient's perspective is as legitimate and valid as the clinician's [183, 184]. The importance of measuring HR-QoL, as an important outcome measurement in CV research, will increase in the future $[180,181]$.

HR-QoL can be measured with generic instruments, disease-specific instruments or a combination of instruments [185]. Generic instruments are intended for general use, irrespective of the illness. A generic instrument makes it possible to compare the HF patient's HR-QoL with HR-QoL among patients with other chronic diseases and also against a general population. Disease-specific instruments are constructed to 
measure how a disease such as HF specifically influences HR-QoL, for example how the magnitude of dyspnoea impacts on the patient's physical function.

The generic instruments fail to focus on the particular concerns of the patient with a specific disease and this has led to the development of disease-specific instruments. The most common generic instrument used in patients with HF is the Short Form 36 (SF-36). SF-36 was a development of the Medical Outcome Study and consists of 36 questions [186]. SF-36 is one of the most frequently used generic instruments [185]. SF-36 is available and validated in a Swedish and Norwegian version [187, 188]. Many HF disease-specific HR-QoL instruments have been developed but one of the most frequently used ones is Minnesota Living with HF (MLwHF) [189]. 
Page 44 


\section{AIMS OF THE THESIS}

\section{General aims}

The overall aims of this thesis were to evaluate the impact of BNP-guiding on CV outcomes compared to conventional HF treatment, as well as to define when in time during follow-up and what cut-off level of BNP that defines a responder, and to evaluate how HR-QoL is influenced by BNP-guiding and how HR-QoL is influenced in responders, and also to evaluate the impact of age and HF duration on clinical outcomes and the impact of age and HF duration on BNP.

\section{Specific aims}

- To examine whether BNP-guided HF treatment improves morbidity and/or mortality when compared with therapy implemented by a treating physician at sites experienced in managing patients with HF according to guidelines.

- To evaluate the optimal cut-off level of BNP to predict death, need for hospitalisation, and worsening HF, and also to determine the optimal time to apply the chosen cut-off value.

- To evaluate how HR-QoL is influenced by HF treatment guided by natriuretic peptide and to study how HR-QoL is influenced in responders compared to non-responders. 
- To evaluate the impact of patient age on clinical outcomes, and to evaluate the impact of duration of the HF disease on outcomes, and the impact of age and HF duration on BNP concentration. 


\section{MATERIAL AND METHODS}

\section{Design of the study}

The UPSTEP study (Use of PeptideS in Tailoring hEart failureProject) was performed in 19 Scandinavian hospitals; 15 hospitals in Sweden and four hospitals in Norway. The UPSTEP study was an investigator-initiated, Scandinavian, randomized, parallel group multicentre study with a PROBE (prospective, randomized, open, and blinded evaluation) design [190]. The patients were randomized into two treatment groups: the BNP-guided group (BNP group) and the control group (CTR group), with conventional HF treatment according to guidelines in 2005 and 2008 [101, 191]. The UPSTEP study started in March 2005 and the last patient was included in April 2008. With a planned follow-up of 12 months the study ended in April 2009.

\section{Study population}

Inclusion criteria in the UPSTEP study were: age > 18 years with verified systolic HF and a LVEF $<40 \%$ (assessed within the last six months), NYHA class II-IV, signs and/or symptoms of worsening HF within the last month (requiring hospitalisation and/or intravenous diuretic treatment or increased daily dosages of diuretics and/or need of intravenous inotropic support). BNP $>150 \mathrm{ng} / \mathrm{L}$ if $<75 y e a r s$, and $>300 \mathrm{ng} / \mathrm{L}$ if $>75$ years. When included, the patients had to be on standard HF treatment according to ESC guidelines applicable at the time of the study [101, 191]. 
The exclusion criteria were: haemodynamically unstable patients; on the waiting list for cardiac surgery (revascularisation, heart valve surgery or heart transplant); patients with a myocardial infarction within the last three months; patients with haemodynamically significant valvular heart disease; patients with impaired renal (screatinine $>250 \mathrm{mmol} / \mathrm{l}$ ) or liver function (liver enzymes more than three times normal value); patients with severely decreased pulmonary function; patients with a limited life expectancy; or patients unable to give informed consent or unable to follow the study schedule, as well as patients participating in another trial.

After the patients signed an informed consent they were randomized 1:1 into the two treatment groups; the BNP-guided group and the control group. The randomisation of patients was carried out in blocks of 12 within each centre.

In the BNP-guided group the HF treatment was guided through the BNP concentration, and the goal was to reduce $\mathrm{BNP}<150 \mathrm{ng} / \mathrm{L}$ if the patient was $<75$ years and $B N P<300 \mathrm{ng} / \mathrm{L}$ if the patient was $\geq 75$ years. There was a treatment algorithm to achieve the BNP goal, namely: increase ACEi/ARB to maximally tolerated or to target dose according to guidelines; increase BB to maximally tolerated or to target dose according to guidelines; add MRA in low dose (spironolactone $25 \mathrm{mg}$ ); add ARB and increase to target dose according to guidelines; increase ACEI/ARB up to twice the target dose; increase BB up to twice the target dose; increase spironolactone up to $50 \mathrm{mg}$. The adjustment of loop diuretic dose was left to the discretion of the investigator. The patients were made aware of the value of BNP in order to increase compliance with the HF treatment.

The control group was treated according to the ESC guidelines in 2005 and 2008, at the discretion of the investigator [101, 191], (Figure 7). The treatment was based on 
changes in clinical signs and symptoms. It was not permitted to take blood samples for BNP in the CTR group during the study except at the study start and at the study end.

Figure 7.

The treatment of heart failure according to Guidelines 2005 and ESC Guidelines 2008 used in the UPSTEP study in the control group, with conventional HF treatment [101, 191].

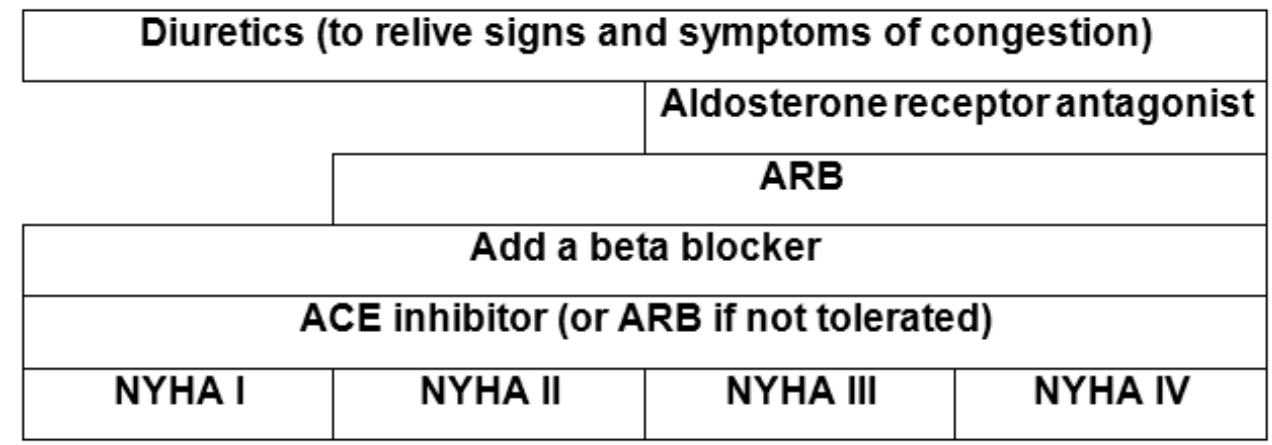

Notes: $A C E=$ Angiotensin-Converting Enzyme, ARBs $=$ Angiotensin Receptor Blockers, $N Y H A=N e w$ York Heart Association Classification

Study visits were scheduled at weeks $2,6,10,16,24,36,48$, and then every six months as long as the study continued. The last included patient was required to have a follow-up time of at least 12 months. At all study visits a medical history, physical examination, blood samples for measurements of electrolytes and renal function, as well as measurement of BNP in the BNP group was included. 


\section{Definitions of clinical endpoints}

The primary outcome variable was a composite of death due to any cause, need for hospitalisation and worsening HF. Worsening HF was defined as a need to increase diuretics orally or intravenously but with no need for hospitalisation.

Secondary outcome variables were total mortality, CV or HF mortality, all-cause hospitalisation, CV or HF-related hospitalisation, and worsening HF.

The predetermined analyses were: age $<75$ years versus age $>75$ years; days in hospital; and responders versus non-responders. Responders were defined as patients who demonstrated a fall in BNP concentration of more than $30 \%$ at week 48 compared to study start. HR-QoL was measured with the SF-36 questionnaire at the study start and at the study end.

All endpoints were adjudicated using a predefined endpoint protocol by a committee with two experienced cardiologists who did not participate in the study and were blinded to the study results. They classified the events according to a predefined protocol into $\mathrm{CV} / \mathrm{HF} /$ /unknown hospitalisation or mortality and worsening HF.

CV mortality was defined as death caused by myocardial infarction, HF, stroke, pulmonary embolism, aortic dissection, cardiac arrhythmia, other CV mortality and sudden death within 24 hours because of $\mathrm{CV}$ symptoms. HF mortality was defined as all mortality caused by HF. Non-CV mortality was defined as all other conditions leading to mortality. CV hospitalisation was defined as myocardial infarction, angina pectoris, coronary interventions, peripheral arterial disease, $\mathrm{HF}$, stroke, pulmonary embolism, aortic dissection, cardiac arrhythmia and deep venous thrombosis requiring an overnight stay in hospital. HF hospitalisation was defined as worsening symptoms and signs demanding intensified treatment with diuretics, need for inotrope 
or increased medication affecting the RAAS-system (ACEi; ARB or MRA). Worsening HF was defined as symptoms and signs demanding intensified treatment with diuretics or increased medication affecting the RAAS-system (ACEi/ ARB) but not requiring an overnight stay in hospital.

In papers I and II the primary outcome variable was a composite of death due to any cause, need for hospitalisation and worsening HF. Worsening HF was defined as a need to increase diuretics orally or intravenously but with no need for hospitalisation.

The secondary outcome variables in papers I and II were; total mortality, cardiovascular mortality, HF-related death, all-cause hospitalisation, cardiovascular hospitalisation, HF-related hospitalisation, and worsening HF.

In paper II we evaluated the best definition of a responder to $\mathrm{HF}$ treatment during follow-up by using the primary outcome variable.

In paper III we evaluated HR-QoL measured at the study start and study end with the SF-36 questionnaire. We evaluated whether BNP-guided HF treatment influenced HR-QoL compared to conventional HF treatment and whether changes in HR-QoL differed depending on whether the patient was a responder to BNP-guided HF treatment or not.

In paper IV the primary endpoint was a composite score containing all hospitalisations, mortality and all events of worsening HF. As a secondary endpoint, the time to first HF hospitalisation and mortality were evaluated. 


\section{Measurement of BNP}

BNP concentrations were analysed on site using the BNP Triage immunoassay technique (Alere Inc., San Diego, CA, USA). In this technique, from the blood sample taken in an EDTA test tube, $250 \mu \mathrm{l}$ is transferred to the test device using the included pipette. The analyte is then transferred by capillary action into the reaction chamber, and the red blood cells are separated by a filter. In the reaction chamber the analyte mixes with fluorescent labelled BNP antibodies and immunoassay reagents. During the reaction, analyte molecules in the sample react with labelled antibodies creating fluorescent analyte. This enables a laser to "read" the levels of BNP and the results are presented within 15 minutes. The reportable range is from five to $5000 \mathrm{ng} / \mathrm{L}$. This analysis technique has been described in detail previously [192, 193]. The coefficient of variation for intra-assay precision is $9.9 \%$ for $71.3 \mathrm{ng} / \mathrm{L}, 12.0 \%$ for $629.9 \mathrm{ng} / \mathrm{L}$, and $12.2 \%$ for $4087.9 \mathrm{ng} / \mathrm{L}$. The coefficient of variation for inter-assay precision is $10 \%$ for $28.8 \mathrm{ng} / \mathrm{L}, 12.4 \%$ for $584 \mathrm{ng} / \mathrm{L}$, and $14.8 \%$ for $1180 \mathrm{ng} / \mathrm{L}$, according to the manufacturer [194]. BNP was analysed on all patients at the study start and at the study end and on every follow-up visit in the BNP-guided group.

\section{Health-Related Quality of Life measurement}

The patients' self-assessed HR- QoL was measured using the Swedish and Norwegian version of the SF-36 at the study start and at the study end $[187,188]$. SF-36 is a well-established HR-QoL instrument and is frequently used in studies of patients with HF and other diseases [185, 195]. The 36-item instrument includes eight domains of HR-QoL; physical functioning (PF) (ten items), role limitations due to physical health problems (RP) (four items), bodily pain (BP) (two items), general 
health (GH) (five items), vitality (VT) (four items), social functioning (SF) (two items), role limitations due to emotional health problems (RE) (three items) and mental health $(\mathrm{MH})$ (five items). The scores were transformed into values between 0 and 100, with a higher score indicating a better HR-QoL [186]. The eight scales can be aggregated into two component summary measures, a physical component score (PCS) and a mental component score (MCS) [187]. All patients filled out the inventory at the study start and at the study end. 


\section{Population: paper I}

The BNP-guided group consisted of 147 patients and the CTR group of 132 patients. Eleven patients dropped out during the study; seven patients in the BNP group and four in the CTR group (Figure 8). The main reason for drop-out was unwillingness to continue. There were no significant differences between the groups in baseline characteristics. In paper I, a subgroup analyses was made using the 140 patients in the BNP group and they were divided into responders and non-responders $(88 / 52$ patients). The definition of a responder was pre-specified as a decrease in BNP concentration of at least 30 percent in week 48 compared to study start.

\section{Figure 8.}

Flow chart of the UPSTEP study, paper I. The BNP-guided (B-type natriuretic peptide) group with147 patients and the control (CTR) group with 132 patients.

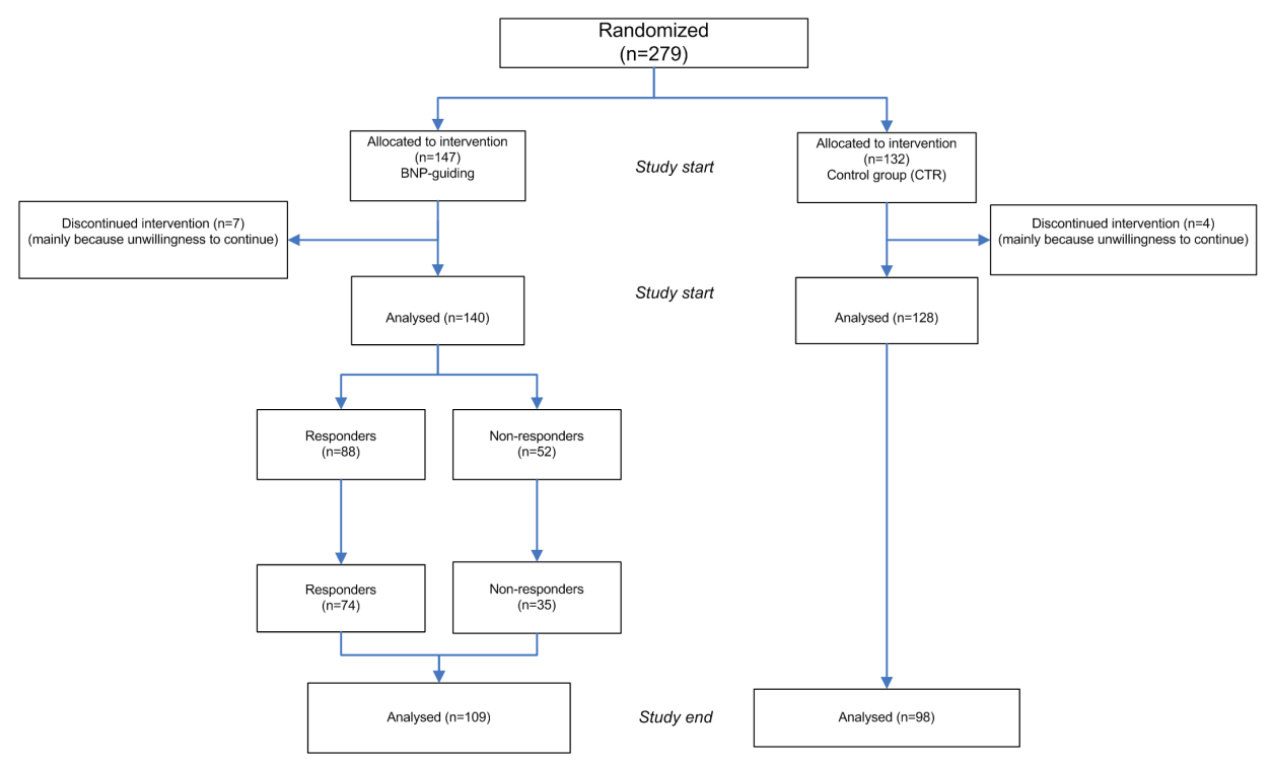




\section{Population: paper II}

The study included all 140 patients of the BNP-guided group from the UPSTEP study. In paper II a responder was defined as a patient with a BNP reduction of at least 40 percent and/or a BNP value $<300 \mathrm{ng} / \mathrm{l}$ in week 16 . They were divided into 84 responders and 56 non-responders (Figure 9).

\section{Figure 9.}

Flow chart of the responders and non-responders defined in paper II.

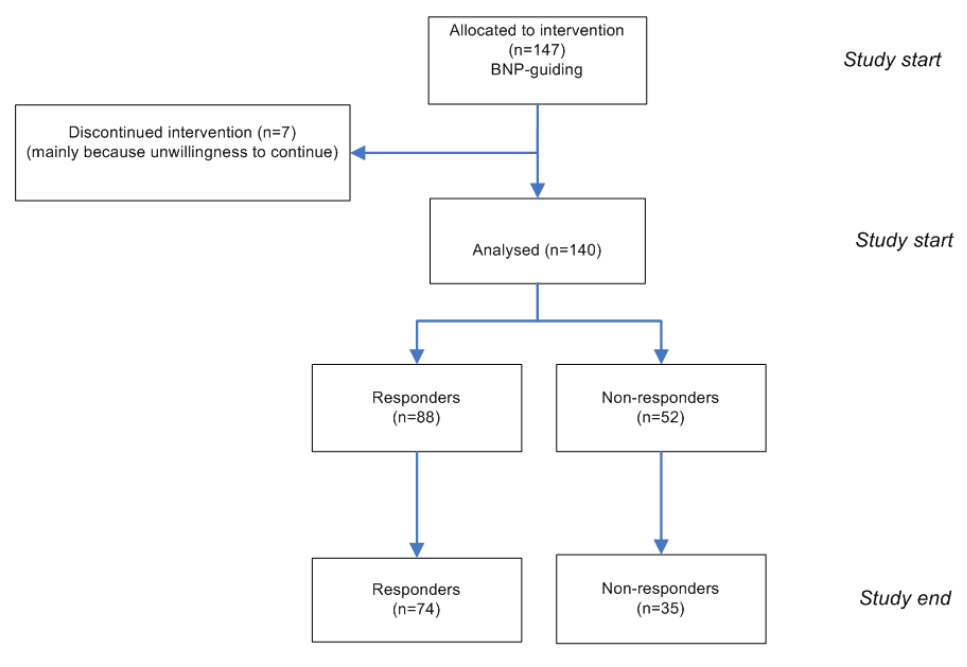

\section{Population: paper III}

At the study start, 258 patients presented evaluable SF-36 questionnaires; 131 in the BNP group and 127 in the control group. At the study end there were 100 patients in 
the BNP-guided group and 98 in the control group who presented evaluable questionnaires from both the study start and the study end (Figure 10).

Of the 131 patients who were randomized to the BNP group in the UPSTEP study, there were 78 responders and 53 non-responders who had answered the HR-QoL questionnaire at the study start, and at the study end there were 68 responders and 32 non-responders (defined in paper II) with evaluable questionnaires (Figure 10).

\section{Figure 10.}

Flow chart of the patients presented in paper III. All patients in the UPSTEP study with evaluable SF36 (Short Form) were included. The definition of responders is the same as in paper II.

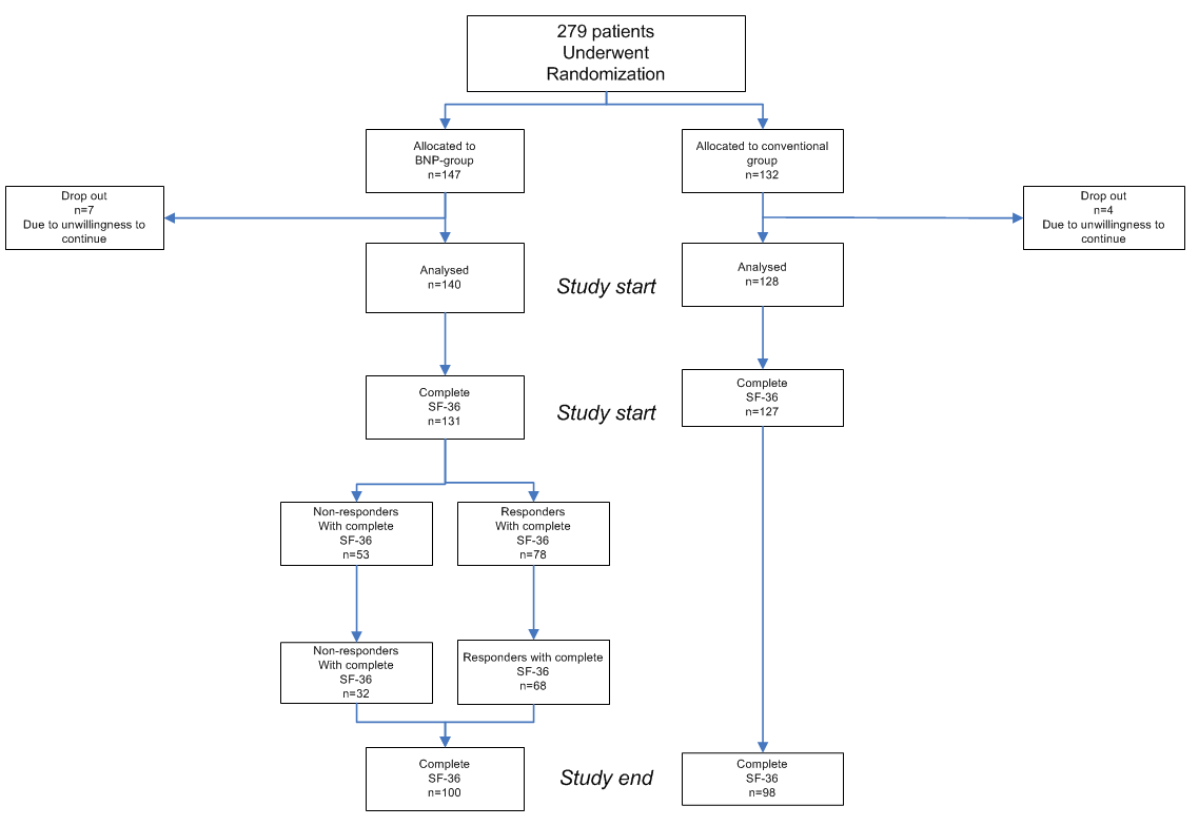




\section{Population: paper IV}

Of the 279 patients in the UPSTEP study, there were data on HF duration for 252 patients; 92 patients (37\%) had HF duration less than one year, 84 patients (33\%) had HF for $1-5$ years and 76 patients (30\%) had HF for more than five years (Figure 11).

\section{Figure 11.}

From the 279 patients included in the UPSTEP study, 252 had data on when the HF diagnosis was set. They were divided into three different durations of HF, less than one year, 1-5 years duration and more than five years of HF duration.

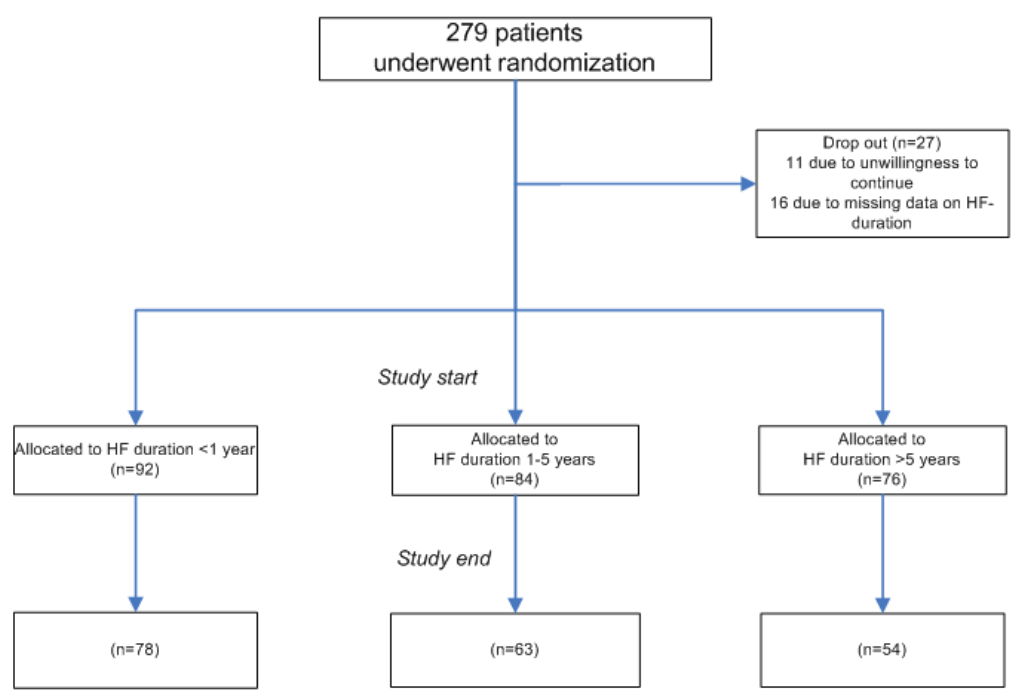




\section{Methods: paper I}

Paper I used a prospective, randomized, open and blinded evaluation to examine whether HF treatment guided by BNP improved outcome ( BNP group) compared to conventional HF treatment (CTR group) and a pre-specified subgroup analysis of responders versus non-responders. Responders were predefined as a decline of BNP level in week 48 compared to study start of at least 30 percent. The definition of a "responder" was the BNP value at week 48 divided by the BNP value at the study start. The factor was then subtracted from 1 , and this was the percentage change for the patient in the evaluated week. If the value was lower than $30 \%$, the patient was a responder in week 48. Patients that died during follow-up, prior to week 48 were classified as responders if any BNP value was reduced by at least 30 percent. Patients with a missing BNP value at week 48 were defined as a responder if any BNP value during follow-up demonstrated a reduction of at least 30 percent compared to baseline.

\section{Methods: paper II}

Paper II used an explorative design to evaluate the optimum cut-off level of BNP and when in time during follow-up (week 6, 10, 16, 24 and 36). To define a "responder" the BNP value at a specific week was divided by the BNP value at the study start. The factor was then subtracted from 1, and this was the percentage change for the patient in that week. If the patient's value was lower than the cut-off percentage value, the patient was defined as a "responder".

We tested a lower limit for the BNP level using the following cut-offs; $\leq 150 \mathrm{ng} / \mathrm{l}, \leq 200$ $\mathrm{ng} / \mathrm{l}, \leq 250 \mathrm{ng} / \mathrm{l}$ and $\leq 300 \mathrm{ng} / \mathrm{l}$. The lower level of BNP $\leq 150 \mathrm{ng} / \mathrm{L}$ was the HF treatment 
goal for patients younger than 75 years, and $\mathrm{BNP} \leq 300 \mathrm{ng} / \mathrm{L}$ was the $\mathrm{HF}$ treatment goal for patients older than 75 years. Patients presenting values below these cut-off levels at follow-up were defined as responders. Groups with fewer than 25 patients were disregarded due to statistical uncertainty.

If the patient had a missing value we used the last known value of BNP. To obtain the optimum cut-off percentage level of BNP we explored the hazard ratios (HR) as obtained by use of a univariate Cox proportional regression analysis for the primary outcome variable from week six until week 36 , and based on changes in BNP levels from a decrease of five percent to a decrease of 60 percent. Our primary outcome variable was a composite endpoint of mortality, morbidity and worsening $\mathrm{HF}$, and used time to first event analysis.

\section{Methods: paper III}

A prospective design based on the UPSTEP study, the SF-36 questionnaires collected at the study start and at the study end were evaluated for the BNP-guided group and the CTR group, and also for the responders versus non-responders defined in paper II.

\section{Methods: paper IV}

Paper IV had an explorative design to evaluate the impact of patient age on outcomes, the impact of duration of the HF disease on outcomes, and the impact of age and HF duration on BNP concentration. 


\section{Statistics}

A power analysis hypothesized that the incidence of the primary outcome variable would be 30 percent in the control group and 15 percent in the BNP-guided group, with a mean follow-up of one year. With 80 percent power at the five percent level of significance, 121 patients were therefore needed in each group. With a withdrawal rate estimated at around $10 \%$, it was calculated that 270 patients would be needed in the UPSTEP trial. The estimated 30 percent incidence of the primary outcomes in the control group was a hypothetic estimation from HF landmark studies [79, 90]. The 50 percent reduction to 15 percent in the BNP-guided group was the risk reduction seen in the only published BNP-guided study in the year 2000 by Troughton et al. that showed $27 \%$ of patients in the BNP group and $53 \%$ in the clinical group had a CV event [163].

The statistical methods are described in Table 2. Descriptive statistics are presented as the arithmetic means and standard deviations (SD) (Papers I, II, III and IV) or median (Papers II, IV), and numbers and percentages for non-parametric data (Papers I, II, III, IV). Comparisons between continuous variables were analysed with the Student unpaired two-sided T-test, whereas a Chi²-test was used for discrete variables (Papers I, II, III, IV). Cox proportional hazard regression analysis was performed to explore if group belonging was an independent predictor of outcome (Papers I, II, IV).

Survival analyses were conducted using Kaplan-Meier evaluation for calculating the time-dependence of the occurrence of events (Paper I, II, IV). A multivariate Cox proportional hazard regression analysis was performed to explore the influence of covariates and outcome (Papers I, II, IV). 
Within-group differences were analysed with a Wilcoxon paired test (paper III). Spearman Rank Order correlation was used to analyse possible correlations between background characteristics and changes in HR-QoL as indicated by the composite score MCS and PCS (Paper III). Missing values in the SF-36 questionnaire were replaced by average score across completed items in the same scale, if the respondent answered at least 50 percent of the items in the scale (Paper III) [196].

Differences between three groups were tested using analysis of variance (Paper IV) and evaluations of outcomes on the ratio scale level p-for trends were analysed (Paper IV). For outcomes on a continuous scale level, linear regression was used (Paper IV). The number of total events variable was evaluated, both transformed as well as untransformed, since the distribution was skewed, with no major differences in the evaluations (Paper IV). In the multivariate Cox proportional hazard regression analysis the following covariates, known to influence cardiovascular risk, were included in the model: male gender, diabetes, hypertension, ischemic heart disease, NYHA III, NYHA IV, Hb (Hemoglobulin) $<120 \mathrm{~g} / \mathrm{l}$, eGFR $<60 \mathrm{ml} / \mathrm{min} 1.73 \mathrm{~m}^{2}$ and age $>75$ years (Paper I). In paper II; male gender, age $>75$ years, NYHA functional classes III and IV, previous smoker, present smoking, ischemic heart disease, diabetes mellitus and eGFR $<60 \mathrm{ml} / \mathrm{min} 1.73 \mathrm{~m}^{2}$ were included as covariates in the multivariate Cox proportional hazard regression analysis. In paper IV the following covariates were included in the multivariate Cox proportional hazard regression analysis: diabetes mellitus, hypertension, male gender, ischemic heart disease and age $>75$ years.

All statistical analyses were performed using commercial statistical software packages (Statistica v9 and v10; Statsoft Inc, Tulsa, OK, USA). 
Table 2.

The statistical methods used in different papers.

\begin{tabular}{|c|c|}
\hline Paper & Statistical methods \\
\hline $\begin{array}{l}\text { (I) Brain natriuretic peptide- } \\
\text { guided treatment does not } \\
\text { improve morbidity and } \\
\text { mortality in extensively } \\
\text { treated patients with chronic } \\
\text { heart failure: responders to } \\
\text { treatment have a significantly } \\
\text { better outcome. }\end{array}$ & $\begin{array}{l}\text { Chi²-test } \\
\text { Student's two-tailed t-test } \\
\text { Pearson's correlation } \\
\text { Spearman correlation coefficients } \\
\text { Mann-Whitney } U \text { test } \\
\text { Cox proportional hazards regression analysis } \\
\text { Multivariate Cox proportional hazards regression } \\
\text { analysis } \\
\text { Kaplan-Meier survival curves }\end{array}$ \\
\hline $\begin{array}{l}\text { (II) Responder to BNP-guided } \\
\text { treatment in heart failure. The } \\
\text { process of defining a } \\
\text { responder. }\end{array}$ & $\begin{array}{l}\text { Chi²-test } \\
\text { Student's two-tailed t-test } \\
\text { Mann-Whitney } U \text { test } \\
\text { Pearson's correlation } \\
\text { Spearman correlation coefficients } \\
\text { Cox proportional hazards regression analysis } \\
\text { Multivariate Cox proportional hazards regression } \\
\text { analysis } \\
\text { Kaplan-Meier survival curves }\end{array}$ \\
\hline $\begin{array}{l}\text { (III) Can BNP-guided therapy } \\
\text { improve health-related quality } \\
\text { of life, and do responders to } \\
\text { BNP-guided heart failure } \\
\text { treatment have improved } \\
\text { health-related quality of life? } \\
\text { Results from the UPSTEP } \\
\text { study. }\end{array}$ & $\begin{array}{l}\text { Chi²-test } \\
\text { Student's two-tailed t-test } \\
\text { Mann Whitney U-test } \\
\text { Pearson's correlation } \\
\text { Spearman rank order correlation coefficients } \\
\text { Wilcoxon paired test }\end{array}$ \\
\hline $\begin{array}{l}\text { (IV) Time since heart failure } \\
\text { diagnosis influences } \\
\text { outcomes more than age } \\
\text { when handling heart failure } \\
\text { patients. Results from the } \\
\text { UPSTEP study. }\end{array}$ & $\begin{array}{l}\text { Chi²-test } \\
\text { Student's two-tailed T-test } \\
\text { Pearson's Chi-square correlation } \\
\text { Spearman correlation coefficients } \\
\text { Wilcoxon paired test }\end{array}$ \\
\hline
\end{tabular}

\section{Ethics}

The UPSTEP study was approved by the Regional Ethical Review Board (Diary nr: M180-04) in Linköping, Sweden. The study was performed according to the World Medical Association Declaration of Helsinki [197]. The participants recieved an oral and written informed consent prior to any study specific activity, according to the Guidelines of the International Conference on Harmonisation in Good Clinical

Practice, ICH-GCP [198]. 


\section{RESULTS}

\section{Result paper I}

The BNP group and CTR group were well balanced according to age, gender, comorbidities, NYHA functional class, BNP concentration and HF treatment (Table $3)$.

\section{Table 3.}

Baseline characteristics of patients in the BNP-guided group (BNP group) and the control group (CTR group).

\begin{tabular}{|c|c|c|c|}
\hline & $\begin{array}{l}\text { CTR-group } \\
(n=132)\end{array}$ & $\begin{array}{l}\text { BNP-group } \\
(n=147)\end{array}$ & P-value \\
\hline Age years mean (SD) & $70.1( \pm 10)$ & $71.6( \pm 9.7)$ & 0.19 \\
\hline Male/Female $n$ & $96 / 36$ & $107 / 40$ & 0.99 \\
\hline Hypertension n (\%) & $30(23)$ & $39(27)$ & 0.46 \\
\hline Diabetes mellitus n (\%) & $48(36)$ & $39(27)$ & 0.08 \\
\hline NYHA II n (\%) & $36(27)$ & $47(32)$ & 0.39 \\
\hline NYHA III n (\%) & $78(59)$ & $76(52)$ & 0.22 \\
\hline NYHA IV n (\%) & $18(14)$ & $22(15)$ & 0.75 \\
\hline LVEF< $<30 \% \mathrm{n}(\%)$ & $76(58)$ & $84(57)$ & 0.94 \\
\hline LVEF $30-40 \% \mathrm{n}(\%)$ & $56(42)$ & $63(43)$ & 0.94 \\
\hline ACEi n (\%) & $92(70)$ & $113(77)$ & 0.17 \\
\hline ARB n (\%) & $46(35)$ & 51 (35) & 0.98 \\
\hline BB n (\%) & $125(95)$ & $137(93)$ & 0.60 \\
\hline MRA n (\%) & $78(59)$ & $81(55)$ & 0.50 \\
\hline Digoxin n (\%) & $28(21)$ & $33(22)$ & 0.80 \\
\hline Diuretics n (\%) & $121(92)$ & $128(87)$ & 0.22 \\
\hline BNP ng/l mean (SD) & $898.9( \pm 915)$ & $808.2( \pm 676)$ & 0.34 \\
\hline median & 596 & 631 & \\
\hline
\end{tabular}

Notes: $\mathrm{ACEi}=$ Angiotensin-converting enzyme inhibitor; $\mathrm{ARB}=$ Angiotensin receptor blocker; $\mathrm{BB}=$ Beta blocker; BNP = B-type natriuretic peptide; LVEF = Left ventricular ejection fraction; NYHA = New York Heart Association functional class; MRA= Mineralocorticoid receptor antagonists; SD=standard deviation. 
Between the BNP group and the CTR group there were no significant differences. However, within the groups there was a significant increase in ACEi and BB during the study, and in the BNP group the doses of ARB were significantly increased (Table 4). As seen in Table 4, at the study start both groups were already receiving medication according to the HF guidelines of 2005 [191].

\section{Table 4.}

Medication during follow-up in BNP group and CTR group at study start, week 48 and at study end.

\begin{tabular}{|c|c|c|c|c|c|c|c|}
\hline Drug & Group & $\begin{array}{l}\text { Start } \\
\text { dose } \\
\text { (mg/day) }\end{array}$ & $\begin{array}{l}\text { p-value } \\
\text { (start- } \\
\text { w.48) }\end{array}$ & $\begin{array}{l}\text { Doses at } \\
\text { w. } 48 \\
\text { (mg/day) }\end{array}$ & $\begin{array}{l}\text { p-value } \\
\text { (w. 48- } \\
\text { end) }\end{array}$ & $\begin{array}{l}\text { Doses at } \\
\text { study end } \\
\text { (mg/day) }\end{array}$ & $\begin{array}{l}\text { p-value } \\
\text { (start-end) }\end{array}$ \\
\hline ARB & $\begin{array}{l}\text { CTR } \\
\text { BNP } \\
\text { p-value* }\end{array}$ & $\begin{array}{l}19 \pm 12 \\
17 \pm 10 \\
0.43\end{array}$ & $\begin{array}{l}0.43 \\
0.0001\end{array}$ & $\begin{array}{l}20 \pm 10 \\
24 \pm 10 \\
0.08\end{array}$ & $\begin{array}{l}0.87 \\
0.60\end{array}$ & $\begin{array}{l}21 \pm 11 \\
25 \pm 9 \\
0.06\end{array}$ & $\begin{array}{l}0.38 \\
<0.0001\end{array}$ \\
\hline BB & $\begin{array}{l}\text { CTR } \\
\text { BNP } \\
\text { p-value* }\end{array}$ & $\begin{array}{l}114 \pm 68 \\
128 \pm 71 \\
0.09\end{array}$ & $\begin{array}{l}<0.0001 \\
0.005\end{array}$ & $\begin{array}{l}157 \pm 84 \\
155 \pm 81 \\
0.90\end{array}$ & $\begin{array}{l}0.99 \\
<0.0001\end{array}$ & $\begin{array}{l}157 \pm 76 \\
156 \pm 89 \\
0.90\end{array}$ & $\begin{array}{l}<0.0001 \\
0.009\end{array}$ \\
\hline ACEi & $\begin{array}{l}\text { CTR } \\
\text { BNP } \\
\text { p-value* }\end{array}$ & $\begin{array}{l}17 \pm 7 \\
17 \pm 7 \\
0.88\end{array}$ & $\begin{array}{l}0.009 \\
0.0002\end{array}$ & $\begin{array}{l}20 \pm 6 \\
21 \pm 8 \\
0.42\end{array}$ & $\begin{array}{l}0.81 \\
0.69\end{array}$ & $\begin{array}{l}20 \pm 6 \\
21 \pm 9 \\
0.22\end{array}$ & $\begin{array}{l}0.03 \\
0.0001\end{array}$ \\
\hline MRA & $\begin{array}{l}\text { CTR } \\
\text { BNP } \\
\text { p-value* }\end{array}$ & $\begin{array}{l}29 \pm 11 \\
27 \pm 11 \\
0.40 \\
\end{array}$ & $\begin{array}{l}0.77 \\
0.80\end{array}$ & $\begin{array}{l}28 \pm 11 \\
28 \pm 12 \\
0.86\end{array}$ & $\begin{array}{l}0.86 \\
0.59\end{array}$ & $\begin{array}{l}28 \pm 13 \\
29 \pm 15 \\
0.64\end{array}$ & $\begin{array}{l}0.64 \\
0.44\end{array}$ \\
\hline
\end{tabular}

Notes: Angiotensin-converting enzyme inhibitor (ACEi) are given in enalapril equivalents (10 $\mathrm{mg}$ ramipril=20 mg lisonopril=150 $\mathrm{mg}$ captopril $=20 \mathrm{mg}$ enalapril). Beta blockers $(B B)$ are given in metoprolol equivalents $(10 \mathrm{mg}$ bisoprolol= $50 \mathrm{mg}$ carvedilol= $100 \mathrm{mg}$ atenolol= $200 \mathrm{mg}$ metoprolol). Angiotensin receptor blocker (ARB) are given in candesartan equivalents (320 mg valsartan $=100 \mathrm{mg}$ losartan $=300 \mathrm{mg}$ irbesartan $=32 \mathrm{mg}$ candesartan). Mineralocorticoid receptor antagonist (MRA) are given in spironolactone equivalents (50 mg eplerenone $=50 \mathrm{mg}$ spironolactone). $w$. =week. Data are shown as mean $\pm S D$ (Standard Deviation), ${ }^{*}=p$-value between groups. Mean doses are given for patients receiving the drug. 


\section{Primary outcome}

In the primary outcome variable (a composite of mortality, hospitalisation and worsening HF) there were no significant differences between the BNP group and CTR group in the univariate Cox proportional hazard regression analysis (HR 0.82, $95 \% \mathrm{Cl} 0.6-1.1 ; \mathrm{p}=0.18)$. Figure 12 illustrates the Kaplan-Meier analyses depicting time to first event analyses for the primary outcome variable, and shows no significant event rate reduction.

\section{Figure 12.}

Kaplan-Meier curves showing primary outcome variable (mortality from any cause, need for hospitalisation, and worsening heart failure) for the BNP-guided and CTR groups.

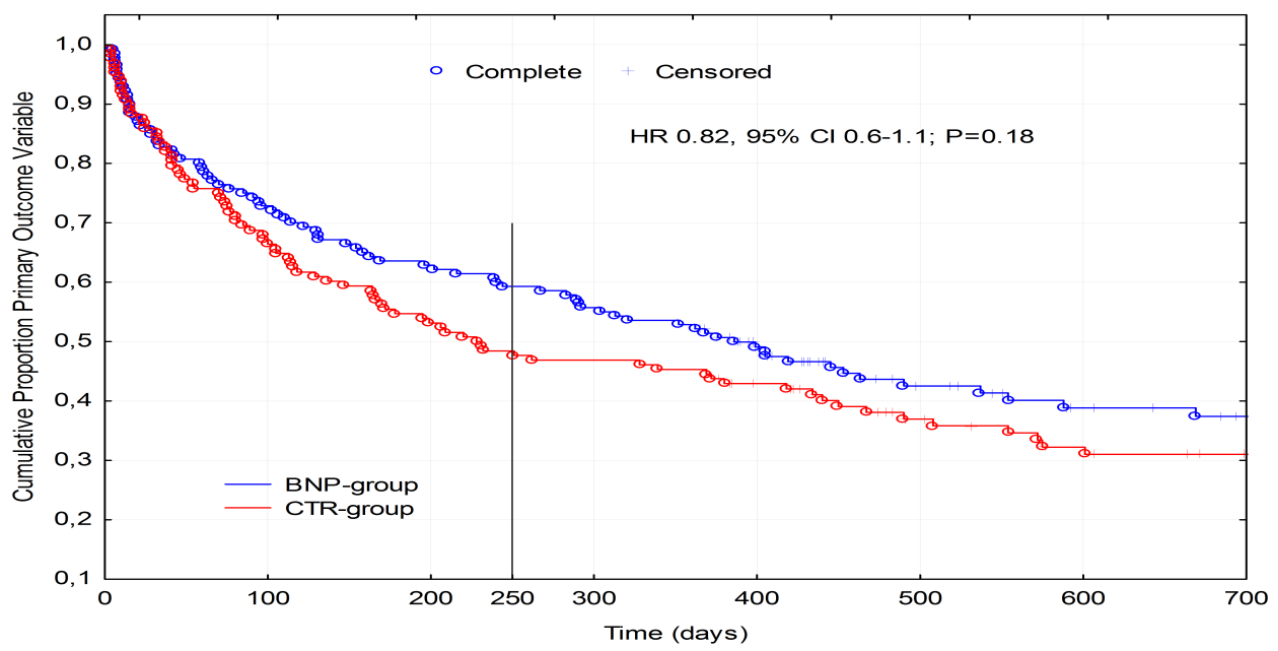

Patients at risk

\begin{tabular}{lllll}
\hline & O days & 200 days & 400 days & 600 days \\
\hline $\begin{array}{l}\text { BNP } \\
\text { group }\end{array}$ & 132 & 88 & 60 & 29 \\
$\begin{array}{l}\text { GTR } \\
\text { group }\end{array}$ & 147 & 68 & 48 & 26 \\
\hline
\end{tabular}




\section{Secondary outcomes}

In our secondary outcome variables there were no significant differences between the BNP-guided HF treatment and CTR groups. The variables analysed were time to CV mortality, HF mortality, all-cause mortality, first CV hospitalisation, HF hospitalisation and all-cause hospitalisation. In time to first worsening episode of HF, the BNP group had 25 events and the CTR group had 40 (HR 0.54, 95\% Cl 0.33$0.88 ; p=0.01)$.

Pre-specified subgroup analyses

In the pre-specified analysis; days in hospital and age under 75 years versus over 75 years there were no significant differences in the primary outcome variable.

The responders to HF treatment were pre-specified as those showing a decrease in BNP of at least 30 percent in week 48 compared to study start. In the BNP-guided group of 140 patients, 88 patients (60\%) fulfilled the criteria for responders. The nonresponders were significantly older and had significantly reduced kidney function (Table 5). 


\section{Table 5.}

Baseline characteristics of the 140 patients in the BNP group divided into responders and nonresponders. Responders were predefined as patients who demonstrated a fall in BNP level of $\geq 30 \%$ at week 48 visit compared to baseline.

\begin{tabular}{lccc}
\hline & Responders & Non-Responders & P-value \\
& $n=88$ & $n=52$ & \\
\hline Age years mean (SD) & $69.2( \pm 10.2)$ & $74.9( \pm 7.8)$ & $<0.001$ \\
Gender male/female & $66 / 22$ & $37 / 15$ & 0.62 \\
Hypertension n (\%) & $20(23)$ & $15(29)$ & 0.42 \\
Diabetes Mellitus n (\%) & $22(25)$ & $15(29)$ & 0.62 \\
LVEF<30\% n (\%) & $55(62)$ & $27(52)$ & 0.22 \\
NYHA functional class & & & \\
II n (\%) & $34(39)$ & $13(25)$ & 0.99 \\
III n (\%) & $42(48)$ & $30(58)$ & 0.25 \\
IV n (\%) & $11(12)$ & $9(17)$ & 0.43 \\
Medication & & & 0.19 \\
RAAS-b n (\%) & $88(100)$ & $51(98)$ & 0.65 \\
BB n (\%) & $81(92)$ & $49(94)$ & 0.63 \\
AA n (\%) & $44(50)$ & $34(65)$ & 0.58 \\
Digoxin n (\%) & $21(24)$ & $11(21)$ & 0.77 \\
Diuretics n (\%) & $75(85)$ & $46(88)$ & 0.59 \\
Laboratory results & & & \\
BNP ng/l mean (SD) & $778.7( \pm 663)$ & & \\
eGFR mL/min/1.73 m ${ }^{2}$ mean (SD) & $67.5( \pm 19.7)$ & & \\
\hline & & & \\
\hline
\end{tabular}

Notes: $A A=$ Aldosterone receptor antagonists; $B B=$ beta blockers; $B N P=B$-type natriuretic peptide; eGFR=estimated glomerular filtration rate (MDRD formula); $L V E F=$ Left ventricular ejection fraction; $N Y H A=$ New York Heart Association functional class; RAAS- $b=$ Renin-angiotensin-aldosterone system-blockade (ACE-inhibitors (ACE=angiotensin-converting enzyme) inhibitor and/or Angiotensin II receptor blockers); $S D=$ standard deviation. 
The responders had a significant risk reduction in the univariate Cox proportional regression analysis of the primary outcome variable (HR: $0.41 ; 95 \% \mathrm{Cl} 0.27-0.63$, $p<0.0001)$ (Figure 13), and this was maintained in a multivariate Cox regression analysis (HR: $0.45 ; 95 \% \mathrm{Cl} 0.29-0.70, \mathrm{p}=0.0005)$. The responders had a significantly better outcome in all secondary outcome variables compared to nonresponders in a univariate Cox regression analysis.

\section{Figure 13.}

Kaplan-Meier graph of primary outcome variable (all-cause mortality, all-cause hospitalisation and worsening HF) for responders ( $\leq 30$ percent reduction in BNP in week 48 compared to study start) and non-responders.

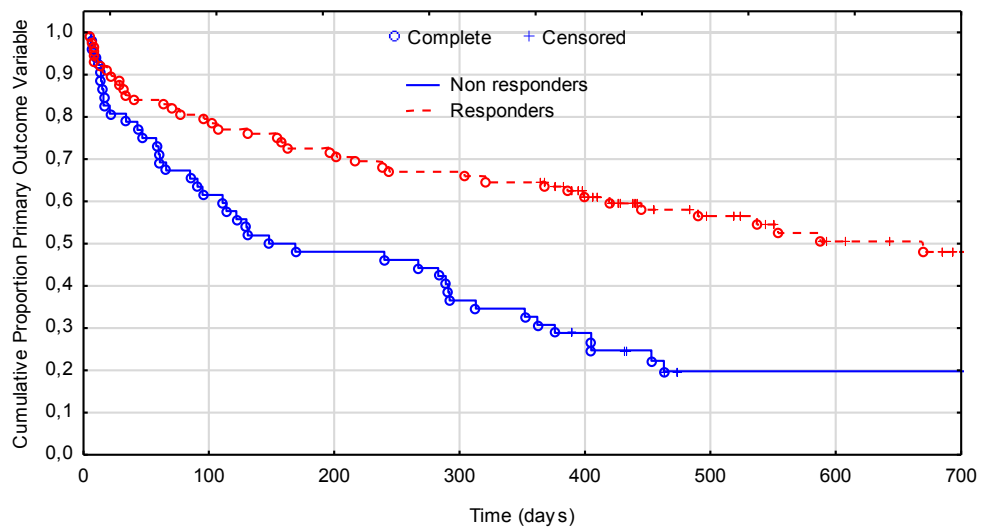

Patients at risk

\begin{tabular}{lcccc}
\hline & 0 days & 200 days & 400 days & 600 days \\
\hline Responders & 88 & 63 & 46 & 23 \\
Non- & 52 & 25 & 14 & 6 \\
responders & & & & \\
\hline
\end{tabular}




\section{Results paper II}

Defining a cut-off level in time and in size

To explore the optimum cut-off level of BNP a univariate Cox proportional hazard regression analysis, applied on our primary outcome variable was used. The highest HR for a non-responder was presented for different percentages of BNP levels and in different weeks (Figure 14). We analysed changes in percentage in BNP from 20-60 percent in different weeks compared to BNP at the study start was analysed regarding the primary outcome variable.

\section{Figure 14.}

Hazard ratio from a univariate Cox regression analysis of the primary outcome variable (all-cause mortality, all-cause hospitalisation and worsening HF) as a reflection of the percentage decrease in BNP in different weeks compared to BNP at study start.

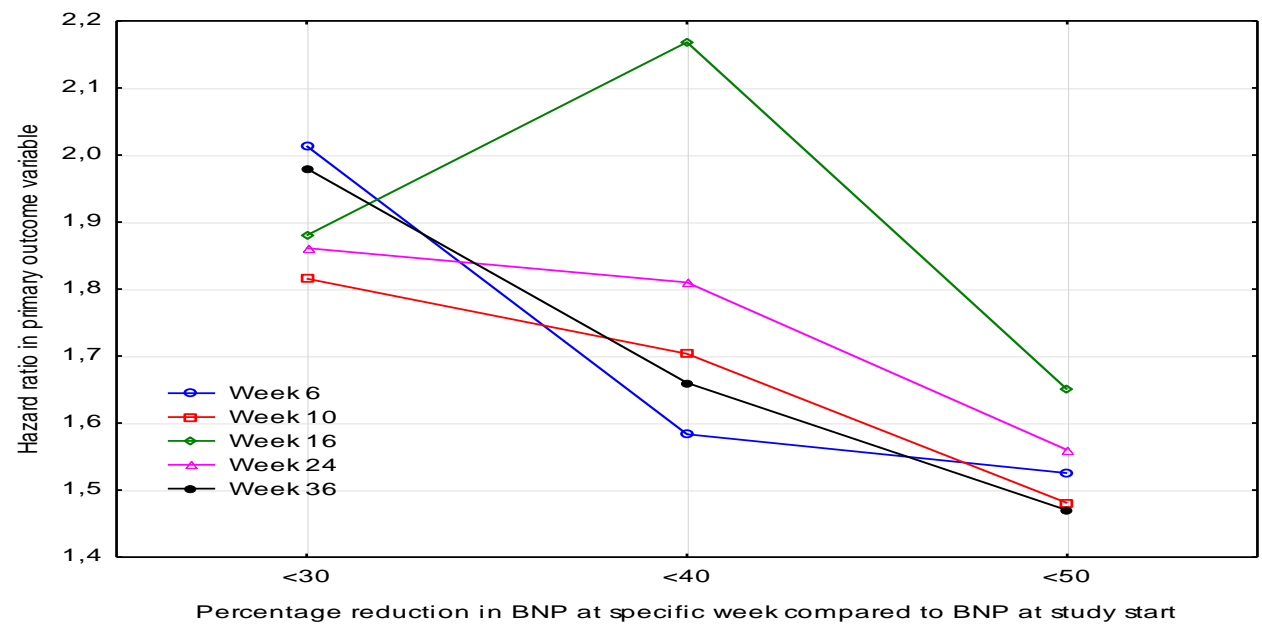


As changes in percentage may be overrated in cases of low baseline levels of BNP, whereas absolute values may be overrated in cases of high BNP levels, we finally combined a fixed BNP value with the percentage change in BNP in a specific week compared to BNP at the study start. In the next step a lower limit was set for the BNP level using the following cut-offs: $\leq 150 \mathrm{ng} / \mathrm{L}, \leq 200 \mathrm{ng} / \mathrm{L}, \leq 250 \mathrm{ng} / \mathrm{L}$ and $\leq 300 \mathrm{ng} / \mathrm{L}$. Patients below these values were defined as responders. We chose BNP $300 \mathrm{ng} / \mathrm{L}$ for two reasons; firstly, it gave the highest HR of the four fixed BNP values, secondly, because patients older than 75 years had BNP $300 \mathrm{ng} / \mathrm{L}$ as a treatment goal in the algorithm. By combining the 40 percent decrease in BNP concentration in week 16 and a $\mathrm{BNP}<300 \mathrm{ng} / \mathrm{L}$, evaluated through a univariate Cox regression analysis on the primary outcome variable (HR 2.43; $95 \% \mathrm{Cl} 1.61-3.65 ; \mathrm{p}<0.00003)$ for nonresponders, the boundaries for a responder were defined.

\section{Baseline characteristics}

By applying the definition of a responder showing a decrease in BNP concentration of at least 40 percent and/or a BNP $<300 \mathrm{ng} / \mathrm{L}$ in week 16 on the study population we found $84(60 \%)$ responders and 56 (40\%) non-responders. Baseline characteristics are shown in Table 6. 


\section{Table 6.}

Baseline characteristics for responders versus non-responders in week 16 at a 40 percent decrease in BNP compared to study start and/or an absolute BNP value $<300 \mathrm{ng} / \mathrm{L}$.

\begin{tabular}{|c|c|c|c|}
\hline & Non-responders & Responders & \\
\hline Characteristics & $\mathrm{n}=\mathbf{5 6}$ & $\mathrm{n}=84$ & p-value \\
\hline Age years (SD) & $74.3( \pm 7.9)$ & $69.3( \pm 10.4)$ & 0.003 \\
\hline Gender male n (\%) & $37(66)$ & $66(79)$ & 0.10 \\
\hline$>75$ years $n(\%)$ & $29(52)$ & $29(35)$ & 0.04 \\
\hline$<60$ years $/>80$ years & $1 / 14$ & $16 / 13$ & 0.04 \\
\hline \multicolumn{4}{|l|}{ Concomitant diseases } \\
\hline Hypertension n (\%) & $33(59)$ & $37(44)$ & 0.08 \\
\hline Diabetes mellitus $n(\%)$ & $15(27)$ & $22(26)$ & 0.94 \\
\hline Coronary artery disease $\mathrm{n}(\%)$ & $33(59)$ & $44(52)$ & 0.45 \\
\hline \multicolumn{4}{|l|}{ Physical examination } \\
\hline Heart rate beats/min (SD) & $72( \pm 15)$ & $79( \pm 20)$ & 0.03 \\
\hline Systolic blood pressure mm Hg (SD) & $125( \pm 21)$ & $126( \pm 23)$ & 0.80 \\
\hline Diastolic blood pressure $\mathrm{mm} \mathrm{Hg}(\mathrm{SD})$ & $74( \pm 12)$ & $75( \pm 14)$ & 0.65 \\
\hline \multicolumn{4}{|l|}{ NYHA functional classes } \\
\hline II $\mathbf{n}$ & 18 & 29 & 0.77 \\
\hline III $\mathbf{n}$ & 29 & 43 & 0.94 \\
\hline IV n & 9 & 11 & 0.62 \\
\hline \multicolumn{4}{|l|}{ Medication } \\
\hline RAAS-b n (\%) & $55(99)$ & $84(100)$ & 0.22 \\
\hline BB n (\%) & $51(92)$ & $79(94)$ & 0.50 \\
\hline MRA n (\%) & $29(52)$ & $48(57)$ & 0.53 \\
\hline Diuretics n (\%) & $48(86)$ & $69(82)$ & 0.40 \\
\hline \multicolumn{4}{|l|}{ Echocardiography (LVEF) } \\
\hline$<30 \% \mathrm{n}$ & 27 & 54 & 0.06 \\
\hline $30-40 \% n$ & 29 & 30 & 0.06 \\
\hline \multicolumn{4}{|l|}{ Laboratory results } \\
\hline BNP ng/l mean (SD) & $805( \pm 688)$ & $795( \pm 680)$ & 0.93 \\
\hline $\mathrm{Hb} \mathrm{g} / \mathrm{l}$ mean (SD) & $135( \pm 14.3)$ & $138( \pm 14.7)$ & 0.67 \\
\hline Creatinine $\mu \mathrm{mol} / \mathrm{l}$ mean (SD) & $115( \pm 38.5)$ & $100( \pm 27.8)$ & 0.009 \\
\hline Potassium mmol// mean (SD) & $4.3( \pm 0.54)$ & $4.3( \pm 0.49)$ & 0.73 \\
\hline
\end{tabular}

Notes: $B B=$ Beta blocker; $B N P=B$-type natriuretic peptide; $H b=$ Haemoglobulin; $L V E F=L$ eft Ventricular Ejection Fraction; MRA=mineralocorticoid receptor antagonist; NYHA = New York Heart Association functional class; RAAS- $b=$ Renin-angiotensin-aldosterone system-blockade; $S D=S t a n d a r d$ deviation 
In baseline characteristics there were differences between the two groups in kidney function and age. However, in a multivariate regression analysis, age did not influence the dependent variable. We evaluated the model by excluding all patients younger than 60 years of age, without influence on the regression results. Our results were consistent without the six patients that died prior to week 16 .

A Cox proportional regression analysis of the primary outcome variable for responders showed a $55 \%$ lower risk (HR 0.45; $95 \% \mathrm{Cl} 0.30-0.69, \mathrm{p}<0.0002$ ) compared to non-responders.

Table 7 presents how medication, laboratory results and physical examination evolved during the study for responders and non-responders. There were no differences between the groups in any variable except for BNP concentration. There were no differences in BNP concentration at the study start, but in week 16 the responder group had a lower mean BNP value compared to the non-responders (244 $\mathrm{ng} / \mathrm{L}( \pm 210)$ versus $784 \mathrm{ng} / \mathrm{L}( \pm 752) ; p<0.0001)$ and the significant difference persisted at the study end. In figure 15 the mean BNP concentrations for responders and non-responders during the study are presented. The responders had significantly lower BNP values compared to non-responders during the study except at the study start. 


\section{Table 7.}

Characteristics of medication, physical examinations and laboratory results at study start, week 16 and at study end for responders and non-responders.

\begin{tabular}{|c|c|c|c|c|c|c|c|}
\hline & \multirow[b]{2}{*}{ Group } & \multicolumn{2}{|l|}{ Study start } & \multicolumn{2}{|l|}{ Week 16} & \multicolumn{2}{|l|}{ Study end } \\
\hline & & $n=140$ & p-value & $n=134$ & $p$-value & $n=109$ & p-value \\
\hline \multicolumn{8}{|l|}{ Physical } \\
\hline \multicolumn{8}{|c|}{ examination } \\
\hline SBP & Responder & $126( \pm 23)$ & \multirow{2}{*}{0.80} & $121( \pm 21)$ & \multirow{2}{*}{0.59} & $128( \pm 18)$ & \multirow{2}{*}{0.08} \\
\hline $\mathrm{mmHg}$ & Non responder & $125( \pm 21)$ & & $119( \pm 20)$ & & $121( \pm 18)$ & \\
\hline DBP & Responder & $75( \pm 14)$ & \multirow{2}{*}{0.65} & $70( \pm 12)$ & \multirow{2}{*}{0.80} & $74( \pm 11)$ & \multirow{2}{*}{0.07} \\
\hline $\mathrm{mmHg}$ & Non responder & $74( \pm 12)$ & & $71( \pm 11)$ & & $70( \pm 9)$ & \\
\hline $\mathrm{HR}$ & Responder & $79( \pm 20)$ & \multirow{2}{*}{0.03} & $66( \pm 13)$ & \multirow{2}{*}{0.48} & $68( \pm 13)$ & \multirow{2}{*}{0.67} \\
\hline $\mathrm{bpm}$ & Non responder & $72( \pm 15)$ & & $68( \pm 13)$ & & $67( \pm 12)$ & \\
\hline \multicolumn{8}{|l|}{ Medication } \\
\hline ACEI & Responder & $16.9( \pm 6.6)$ & \multirow{2}{*}{0.70} & $20.3( \pm 5.9)$ & \multirow{2}{*}{0.38} & $22.0( \pm 8.6)$ & \multirow{2}{*}{0.39} \\
\hline $\mathrm{mg} / \mathrm{day}$ & Non responder & $17.5( \pm 6.8)$ & & $19.2( \pm 6.0)$ & & $20.2( \pm 8.7)$ & \\
\hline ARB & Responder & $15.8( \pm 9.0)$ & \multirow{2}{*}{0.70} & $21.7( \pm 9.7)$ & \multirow{2}{*}{0.25} & $25.9( \pm 8.9)$ & \multirow{2}{*}{0.12} \\
\hline $\mathrm{mg} / \mathrm{day}$ & Non responder & $17.0( \pm 11.9)$ & & $19.0( \pm 10.5)$ & & $22.1( \pm 10.2)$ & \\
\hline MRA & Responder & $26.6( \pm 8.8)$ & \multirow{2}{*}{0.66} & $25.2( \pm 9.9)$ & \multirow{2}{*}{0.78} & $27.7( \pm 16.0)$ & \multirow{2}{*}{0.39} \\
\hline $\mathrm{mg} / \mathrm{day}$ & Non responder & $27.6( \pm 11.3)$ & & $24.7( \pm 9.2)$ & & $31.2( \pm 13.1)$ & \\
\hline BB & Responder & $125.8( \pm 74.1)$ & \multirow{2}{*}{0.90} & $151.5( \pm 82.9)$ & \multirow{2}{*}{0.74} & $165.1( \pm 91.4)$ & \multirow{2}{*}{0.11} \\
\hline $\mathrm{mg} / \mathrm{day}$ & Non responder & $127.5( \pm 67.7)$ & & $146.7( \pm 69.2)$ & & $135.4( \pm 82.7)$ & \\
\hline \multicolumn{8}{|l|}{ Laboratory } \\
\hline \multicolumn{8}{|l|}{ results } \\
\hline Potassium & Responder & $4.3( \pm 0.49)$ & \multirow{2}{*}{0.73} & $4.5( \pm 0.7)$ & 030 & $4.5( \pm 0.5)$ & 020 \\
\hline $\mathrm{mmol} / \mathrm{l}$ & Non responder & $4.3( \pm 0.54)$ & & $4.4( \pm 0.5)$ & 0.00 & $4.4( \pm 0.4)$ & 0.29 \\
\hline Creatinine & Responder & $100( \pm 28.0)$ & 001 & $118( \pm 41.4)$ & 0.58 & $151( \pm 38.3)$ & 0.43 \\
\hline$\mu \mathrm{mol} / \mathrm{l}$ & Non responder & $115( \pm 38.5)$ & 0.07 & $114( \pm 40.8)$ & 0.58 & $122( \pm 46.8)$ & 0.43 \\
\hline BNP & Responder & $795( \pm 680)$ & 093 & $244( \pm 210)$ & (2) & $290( \pm 337)$ & קחמחم \\
\hline $\mathrm{ng} / \mathrm{l}$ & Non responder & $805( \pm 688)$ & 0.93 & $784( \pm 752)$ & $<0.0001$ & $641( \pm 604)$ & 0.0002 \\
\hline
\end{tabular}

Notes: $A C E I=$ Angiotensin receptor inhibitor, $A R B=$ Angiotensin receptor blocker, $B B=B$ Beta blocker, $B N P=B$-type Natriuretic

Peptide, $D B P=$ Diastolic blood pressure, $H R=$ Heart rate, $M R A=$ mineralocorticoid receptor antagonist, $S B P=S y s t o l i c$ blood pressure. Data are shown as mean, $\pm S D=$ standard deviation. Doses are given for patients receiving the drug. ACEI are given in Enalapril equivalents (20 mg Enalapril=10 mg Ramipril=20 mg Lisinopril=150mg Captopril. ARB are given in Candesartan equivalents (32 mg Candesartan=320 mg Valsartan=100 mg Losartan=300 mg Irbesartan). BB are given in Metoprolol equivalents (200 mg Metoprolol=100 mg Atenolol=10 mg Bisoprolol=50 mg Carvedilol. MRA are given in spironolactone equivalents (25 mg Spironolactone $=25 \mathrm{mg}$ Eplerenone). 


\section{Figure 15.}

$B N P$ in different weeks for responders and non-responders, with a significant difference between the groups in all weeks except at study start.

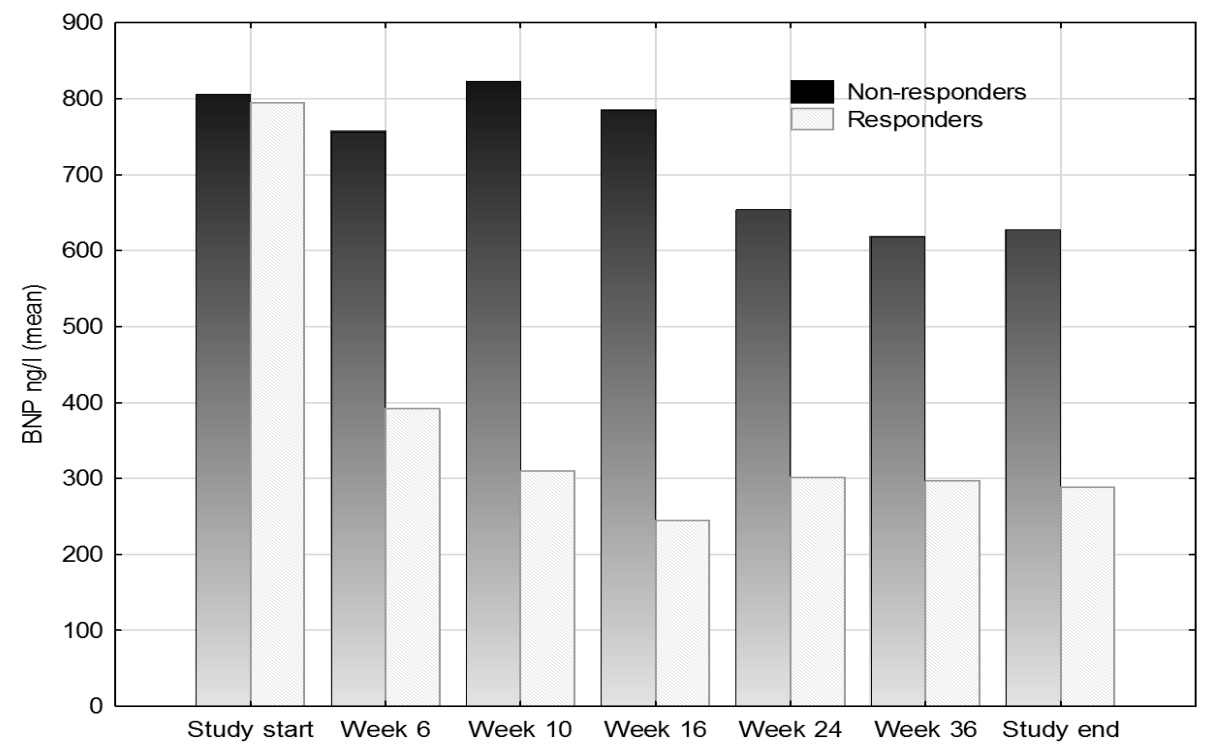

\section{Primary outcome variables}

The primary outcome variable (a composite of all-cause mortality, all-cause hospitalisation and worsening HF) is illustrated with a Kaplan-Meier analysis depicting time to first event in figure 16 , and shows a significant event rate reduction for responders.

With a univariate Cox proportional regression analysis for the primary outcome events, there was a 59 percent risk reduction for responders, HR $0.41(95 \% \mathrm{Cl} 0.27$ $0.62, p<0.0001)$ and the difference between responders and non-responders was maintained in a multivariate Cox regression analysis HR 0.45 (95 \% Cl 0.30-0.69, $\mathrm{p}<0.0002)$. 
Figure 16.

Kaplan-Meier graph showing the primary outcome for responders and non-responders.

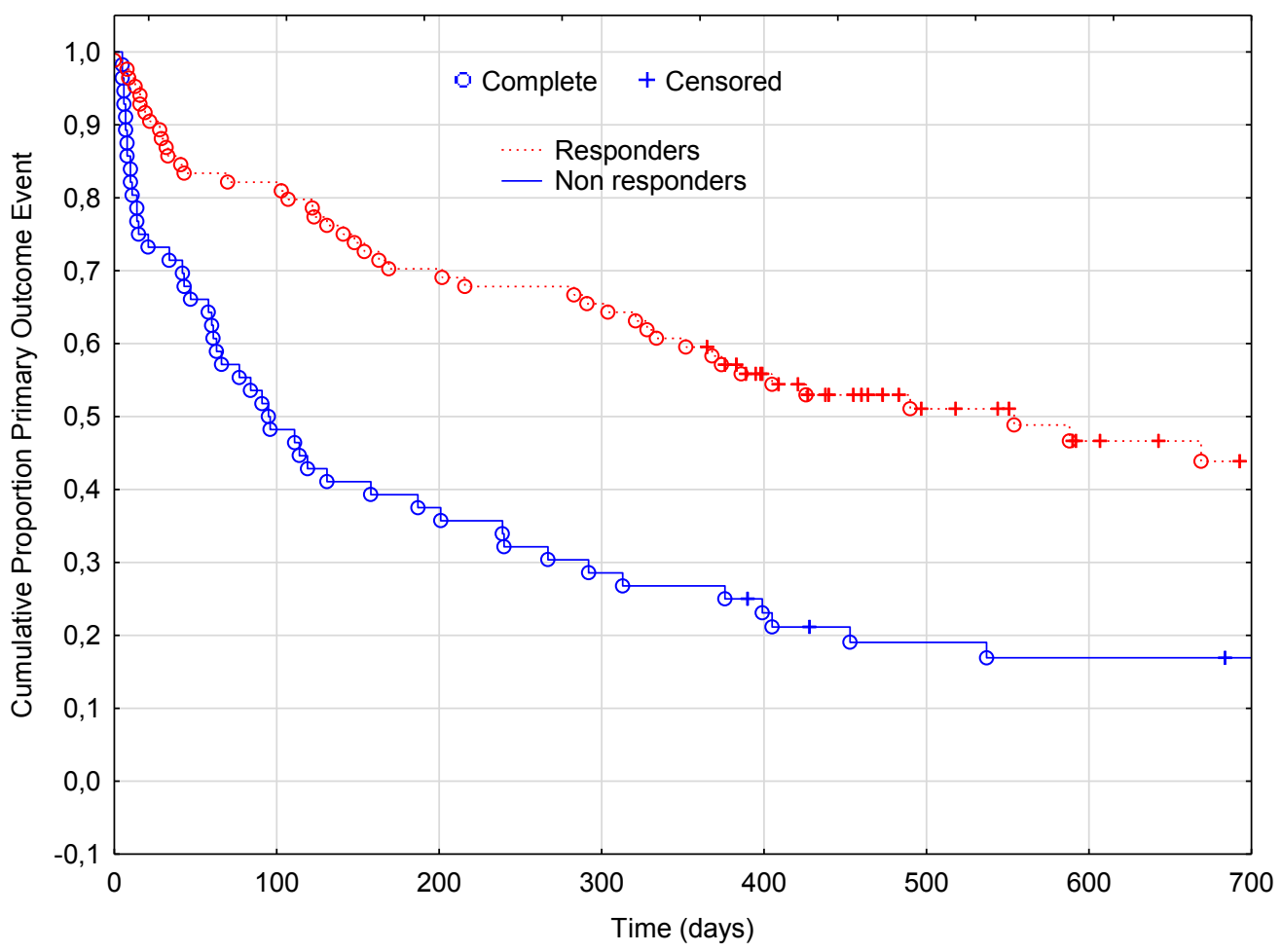

Patients at risk

\begin{tabular}{lllll}
\hline & 0 days & 200 days & 400 days & 600 days \\
\hline Responders & 84 & 59 & 40 & 19 \\
Non- & 56 & 21 & 12 & 8 \\
responders & & & &
\end{tabular}




\section{Secondary outcome variables}

In the responder group, three patients died from HF causes, compared to 18 in the non-responder group $(p<0.0001)$ and the corresponding results for $\mathrm{CV}$ mortality were seven responders and 21 non-responders $(p<0.0001)$. For HF hospitalisation; 36 events for responders and 75 for non-responders $(p<0,003)$. For CV hospitalisation; 73 events versus 107 events $(p<0.003)$ and finally worsening HF; 11 events for responders and 31 events for non-responders $(p<0.002)$. The responders spent fewer days in hospital for HF reasons: 2.3 (SD 9.2) versus 9.4 days (SD 17.7) for non-responders $(p<0.002)$. Corresponding results for CV hospitalisation were 4.4 days (SD10.8) versus 14.9 days (SD 21.4) for non-responders $(p<0.0002)$. There were no significant differences between the groups in non-CV hospitalisations.

\section{Percentage model compared to an absolute reduction model}

The most used cut-off level for a responder in the literature is an absolute cut-off level. Gaggin et al. defined a responder as a patient with a reduction in NTproBNP $\leq 1000 \mathrm{ng} / \mathrm{L}$ [199]. To evaluate our percentage model in comparison with an absolute cut-off model, we converted our BNP values into estimated NT-proBNP values. In the conversion we used a formula previously described by Sykes et al. (BNPx4.94+71.7-221.2(if female)=NT-proBNP [200]. We compared the two models in a multivariate setting including variates known to influence $\mathrm{CV}$ risk. The two models were evaluated at weeks 6-36 and with a 30,40 or 50 percent decrease in BNP with a lower limit of $300 \mathrm{ng} / \mathrm{L}$ in BNP (Table 8). The percentage model gives independent and significant information even when competing with an absolute model. 


\section{Table 8.}

Comparison between percentage model with a BNP cut point of $300 \mathrm{ng} / \mathrm{l}$, against an absolute model with definitions used by Januzzi and Gaggin, with a NT-proBNP cut point of $1000 \mathrm{pg} / \mathrm{ml}$ applied in a multivariate Cox proportional regressions model.

\begin{tabular}{lcccccc}
\hline & \multicolumn{3}{c}{ Absolute model } & \multicolumn{3}{c}{ Percentage model } \\
\hline Time and \% decrease & $\begin{array}{c}\text { Hazard } \\
\text { ratio }\end{array}$ & 95\% Cl & P-value & ratio & $95 \%$ Cl & P-value \\
\hline and BNP< 300 ng/l & & & & & & \\
\hline Week 6, 30\% & 1.16 & $0.63-2.12$ & 0.64 & 1.67 & $1.02-2.73$ & 0.04 \\
Week 6, 40\% & 1.12 & $0.59-2.11$ & 0.73 & 1.60 & $0.97-2.65$ & 0.07 \\
Week 6, 50\% & 1.13 & $0.58-2.20$ & 0.71 & 1.47 & $0.86-2.51$ & 0.16 \\
Week 10, 30\% & 0.80 & $0.43-1.50$ & 0.49 & 1.85 & $1.14-3.00$ & 0.01 \\
Week 10, 40\% & 0.72 & $0.38-1.37$ & 0.31 & 2.13 & $1.28-3.55$ & 0.004 \\
Week 10, 50\% & 0.78 & $0.40-1.52$ & 0.47 & 1.71 & $0.99-2.97$ & 0.06 \\
Week 16, 30\% & 0.99 & $0.55-1.78$ & 0.96 & 2.08 & $1.27-3.42$ & 0.004 \\
Week 16, 40\% & 0.92 & $0.50-1.69$ & 0.79 & 2.26 & $1.35-3.75$ & 0.002 \\
Week 16, 50\% & 1.03 & $0.54-1.94$ & 0.94 & 1.74 & $1.01-2.99$ & 0.005 \\
Week 24, 30\% & 1.38 & $0.75-2.56$ & 0.30 & 1.53 & $0.94-2.48$ & 0.09 \\
Week 24, 40\% & 1.52 & $0.82-2.80$ & 0.18 & 1.30 & $0.80-2.11$ & 0.30 \\
Week 24, 50\% & 1.45 & $0.78-2.70$ & 0.24 & 1.39 & $0.85-2.29$ & 0.19 \\
Week 36, 30\% & 0.70 & $0.38-1.32$ & 0.27 & 1.63 & $1.22-4.11$ & 0.02 \\
Week 36, 40\% & 0.64 & $0.33-1.26$ & 0.20 & 1.62 & $1.07-3.88$ & 0.02 \\
Week 36, 50\% & 0.66 & $0.34-1.31$ & 0.23 & 1.56 & $0.87-2.34$ & 0.27 \\
\hline Wotes In the m4 & & & & & & \\
\hline
\end{tabular}

Notes: In the multivariate model, adjustments have been made for age $>75$ years, diabetes mellitus, eGFR<60mI/min, hypertension, ischemic heart disease, NYHA class III or IV, male gender.

Comparison between week and percentage change included with an absolute BNP at $300 \mathrm{ng} / \mathrm{l}$ and an absolute cut point of NT-proBNP at 1000 ng/l suggested by Januzzi and Gaggin. 


\section{Result paper III}

\section{Health-related Quality of life}

\section{BNP-guided and CTR groups}

At the study start, 258 of $268(96 \%)$ of the patients participating in the UPSTEP study had answered the SF-36 questionnaire (Figure 9). The mean follow-up time for the 198 patients (100 in the BNP group / 98 in the CTR group) that completed the study was 712 days $(S D \pm 279)$. In figure 17 the changes in perceived HR-QoL for the BNP-guided group and CTR group in SF 36 are presented. Between the BNP-guided group and the CTR group there were no significant differences. However, within the groups significant changes could be seen; in the CTR group in six of the eight domains (RP, $p<0.001, B P, p<0.001, V T, p=0.03$, SF, $p<0.0001, R E, p<0.01, M H$, $p<0.01$ ), in the BNP group in four of the eight domains (PF, $p<0.01, R P, p<0.01, V T$, $p<0.001$ and $M H, p<0.01)$. For the composite dimensions score, PCS and MCS, the CTR group improved in PCS $(p<0.001)$, and MCS $(p<0.002)$ and the BNP-guided group improved significantly in PCS, $(p<0.001)$. 


\section{Figure 17.}

Change in perceived Hr-QoL during the study in SF 36 during the study, control (CTR) group and BNP-guided group.

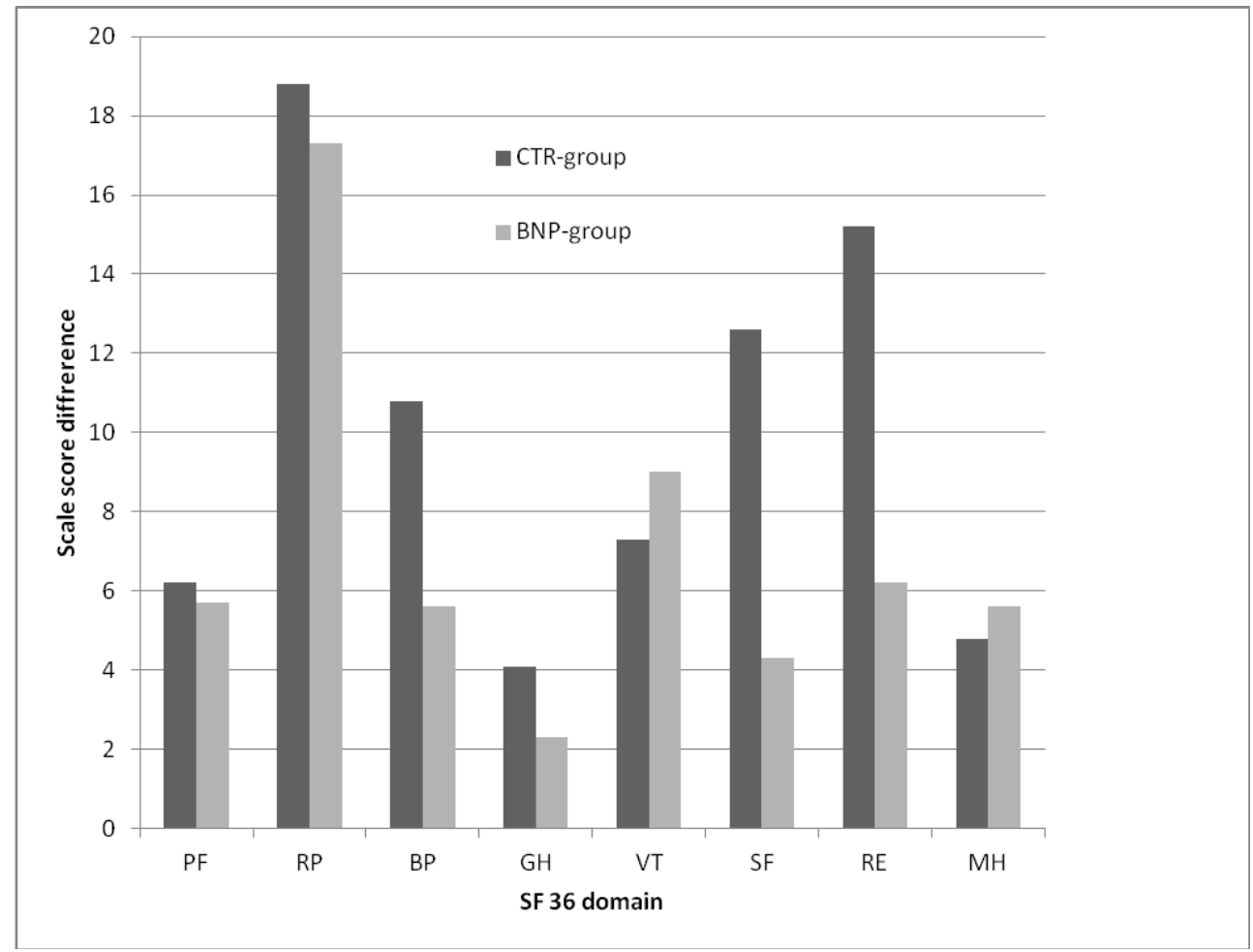

Notes: No significant differences between the two groups could be seen.

Responders and non-responders

At the study end there were 68 responders and 32 non-responders with evaluable SF-36 questionnaires, and the mean follow-up time was 675 (SD \pm 266$)$ days for responders and $794(S D \pm 286)$ for non-responders, $p=0.04$. As seen in figure 18, presenting the change in HR-QoL during the study, HR-QoL improved in all eight domains for responders $(n=78)$ and in seven domains for non-responders $(n=53)$ who had answered the SF-36 questionnaire. At the study start the responders already 
had significantly better scores in three of the eight SF-36 domains (PF ( $p=0.001)$, GH $(p=0.01), S F(p=0.006))$ and in the summary score PCS $(p=0.007)$ compared to the non-responders. Within-group analyses of changes from the study start showed significant improvements for responders in four domains; RP $(P<0.004)$, VT $(p<0.002), S F(p=0.03), M H(p=0.02)$ and for the non-responders the analysis was significantly improved in one domain; PF $(p=0.03)$.

In the BNP-guided group there were 252 serious adverse events compared to 301 in the CTR group. For worsening HF there were 41 events in the BNP-guided group and 57 in the CTR group. This might indicate that the CTR group spent more time in hospital and thus met cardiologists and HF nurses more often.

Figure 18.

Change in HR-QoL during the study for responders and non-responders.

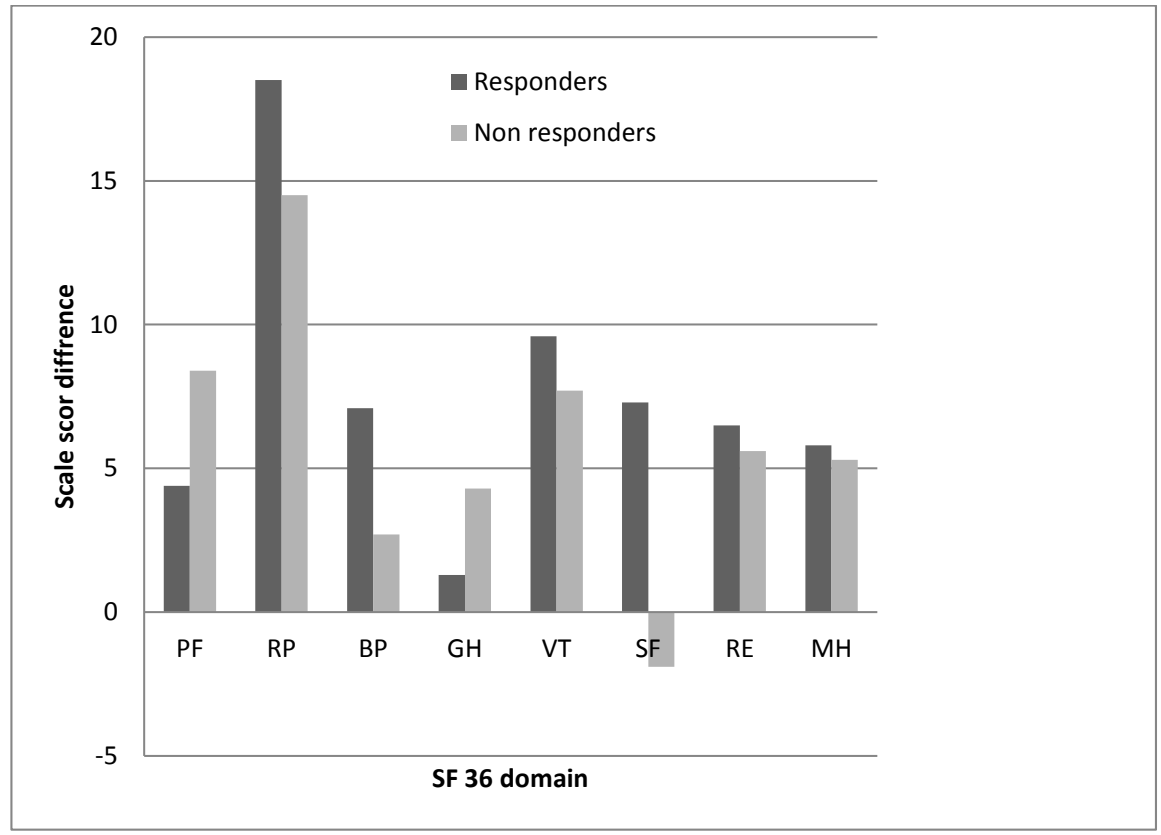




\section{Results paper IV}

\section{Baseline characteristics}

In the UPSTEP study, 252 patients with known HF duration and with a mean age of 71 (range 33-91) and a mean follow-up 645 days $(S D \pm 310)$ were included. In baseline characteristics (Table 9), significant differences between the three HF duration groups were seen in: pulmonary disease, systolic and diastolic blood pressure, ischemic heart disease and with increasing HF duration reduced NYHA functional class.

\section{Impact of age on outcomes}

The 252 patients were evaluated regarding the association between age and the composite endpoint score. The study population was divided into younger than 75 years $(n=155)$ and over 75 years $(n=97)$. The evaluation showed no significant differences between the groups regarding the total number of events $(357 / 155$ versus 274/97), $p=0.25$. In the next step the population was divided into tertiles according to age. The first tertile had 169 events, the second tertile had 237 events and the third tertile had 225 events, (169/84 events versus 237/84, 225/84; $p=0.21$ ), indicating that age has no impact on outcomes. 


\section{Table 9.}

Baseline characteristics for the study population according to duration of heart failure diagnosis where group 1 had a heart failure diagnosis less than one year ago, group 2, a heart failure diagnosis 1-5 years ago and group 3 a heart failure diagnosis more than 5 years.

\begin{tabular}{|c|c|c|c|c|c|}
\hline Characteristics & $\begin{array}{c}\text { Group } 1 \\
n=92(37 \%)\end{array}$ & $\begin{array}{c}\text { Group } 2 \\
n=84(33 \%)\end{array}$ & $\begin{array}{c}\text { Group } 3 \\
n=76(30 \%)\end{array}$ & $\begin{array}{c}\text { Total } \\
\text { population } \\
\mathbf{n}=\mathbf{2 5 2}\end{array}$ & p-value \\
\hline \multicolumn{6}{|l|}{ Background } \\
\hline Age years (SD) & $69.3( \pm 11.4)$ & $71.6( \pm 8.9)$ & $71.4( \pm 8.8)$ & $70.7( \pm 9.9)$ & 0.59 \\
\hline Gender male, n (\%) & $66(72)$ & $59(70)$ & $59(78)$ & $184(73)$ & 0.54 \\
\hline Atrial fibrillation/flutter, $\mathrm{n}(\%)$ & $27(29)$ & $31(37)$ & $27(36)$ & $85(34)$ & 0.53 \\
\hline CVL, n (\%) & $8(9)$ & $18(21)$ & $14(18)$ & $40(16)$ & 0.053 \\
\hline Hypertension, n (\%) & $36(39)$ & $44(52)$ & $28(37)$ & $108(43)$ & 0.09 \\
\hline IHD, n (\%) & $52(57)$ & $60(71)$ & $57(75)$ & $169(67)$ & 0.02 \\
\hline Anaemia, n (\%) & $25(27)$ & $22(26)$ & $23(30)$ & $70(28)$ & 0.84 \\
\hline Diabetes Mellitus, n (\%) & $23(25)$ & $29(35)$ & $29(38)$ & $81(32)$ & 0.16 \\
\hline eGFR,60 mL/min/ & $43(47)$ & $45(54)$ & $41(54)$ & $129(51)$ & 0.56 \\
\hline \multicolumn{6}{|l|}{$1.73 \mathrm{~m}^{2}, \mathrm{n}(\%)$} \\
\hline Pulmonary disease, n (\%) & $5(5)$ & $11(13)$ & $16(21)$ & $32(13)$ & 0.01 \\
\hline \multicolumn{6}{|l|}{ NYHA functional classes } \\
\hline II n (\%) & $40(44)$ & $26(31)$ & $10(13)$ & $76(30)$ & 0.0001 \\
\hline III n (\%) & $45(49)$ & $46(55)$ & $48(63)$ & $139(55)$ & 0.2 \\
\hline IV n (\%) & $6(7)$ & $12(14)$ & $18(24)$ & $36(14)$ & 0.007 \\
\hline \multicolumn{6}{|l|}{ Physical examination } \\
\hline Heart rate beats/min (SD) & $75( \pm 18)$ & $73( \pm 16)$ & $78( \pm 18)$ & $75( \pm 18)$ & 0.21 \\
\hline Systolic blood pressure, mm Hg (SD) & $127( \pm 22)$ & $126( \pm 22)$ & $118( \pm 22)$ & $124( \pm 22)$ & 0.04 \\
\hline Diastolic blood pressure, mm Hg (SD) & $77( \pm 12)$ & $76( \pm 12)$ & $69( \pm 12)$ & $74( \pm 12)$ & 0.0007 \\
\hline \multicolumn{6}{|l|}{ Echocardiography (LVEF) } \\
\hline$<30 \%$ n $(\%)$ & $56(61)$ & $43(50)$ & $44(58)$ & $143(57)$ & 0.42 \\
\hline $30-40 \%$ n (\%) & $36(39)$ & $42(51)$ & $32(42)$ & $110(39)$ & 0.42 \\
\hline \multicolumn{6}{|l|}{ Medication } \\
\hline RAAS-b n (\%) & $91(99)$ & $82(98)$ & $75(99)$ & $248(98)$ & 0.77 \\
\hline BB n (\%) & $86(92)$ & $80(95)$ & $72(95)$ & $238(94)$ & 0.87 \\
\hline MRA n (\%) & $42(46)$ & $50(60)$ & $50(66)$ & $142(56)$ & 0.03 \\
\hline \multicolumn{6}{|l|}{ Laboratory results } \\
\hline BNP ng/l mean (SD) & $836(743)$ & $788(762)$ & $990(976)$ & $867(827)$ & 0.26 \\
\hline Median & 631 & 512 & 679 & 616 & \\
\hline eGFR $\mathrm{mL} / \mathrm{min} / 1.73 \mathrm{~m}^{2}$ mean (SD) & $63.9(19.9)$ & $57.8(19.6)$ & $60.3(23.2)$ & $60.7(20.9)$ & 0.15 \\
\hline Potassium mmol/1 mean (SD) & $4.2(0.4)$ & $4.3(0.6)$ & $4.4(0.5)$ & $4.2(0.5)$ & 0.04 \\
\hline
\end{tabular}

Notes: Anaemia definition; Male $H b<130 \mathrm{~g} / \mathrm{dl}$, Female $H b<120 \mathrm{~g} / \mathrm{dl}$; BB:Beta-blocker; BNP:B-type Natriuretic Peptide;CVL:Cerebrovascular lesion; eGFR:estimated glomerular filtration rate (MDRD formula); IHD:Ischemic Heart Disease; LVEF:Left Ventricular Ejection Fraction; MRA:Mineralocorticoid Receptor Antagonist; NYHA:New York Heart Association functional class; RAS-b:RAS blockade (ACEinhibitors and/or angiotensin II receptor blockers), SD:standard deviation. P-value was obtained though Kruskal-Wallis test or Pearson Chi-square test. 


\section{Impact of time since heart failure diagnosis on outcomes}

The population were divided into tertiles regarding HF duration and the composite score was evaluated. In the first tertile (0-9 months of duration) 137 events were registered. In the second tertile (9 months-4. 1 years of duration) 203 events could be registered, and in the third tertile (4.1-26.5 years of duration) 291 events were registered. With increasing HF duration, significantly more events occurred, $p<0.0006$.

In clinical practice the divisions into 0-1 year, $1-5$ years and more than five years are more appropriate. Applying this distribution to the study population, the group with a HF duration of less than one year consisted of 92 patients (37\%), they had 144 events (mean 1.6 events; $\mathrm{SD} \pm 1.9$ ), the group with HF duration of $1-5$ years consisted of 84 patients (33\%) and had 252 events (mean 3 events; SD \pm 4.4 ), and finally the group with an HF duration of more than five years consisted of 76 patients (30\%) and had 235 events (mean 3.1 events; $\mathrm{SD} \pm 3.5$ ). There was a significant difference $p<0.004$, between the three groups, where those with a longer HF duration had more events.

We also evaluated the impact on first HF hospitalisation and mortality for the groups. Groups with HF duration less than one year had 24 events, 1-5 years had 39 events and HF duration more than five years had 42 events, $p=0.0001$. In figure 19 , time to first events are illustrated in a Kaplan-Meier graph. There are significant differences between all groups and with increasing HF duration there is an increasing risk for $\mathrm{HF}$ hospitalisation or HF mortality. 


\section{Figure 19.}

Kaplan-Meier curves of HF hospitalisation and HF mortality for patients with HF duration< 1 year, 1-5 years and more than five years. Significant differences between all groups; between group 1 and group 2: $p<0.02$, between group 2 and group 3, $p<0.04$ and between group 1 and group $3, p<0.0001$.

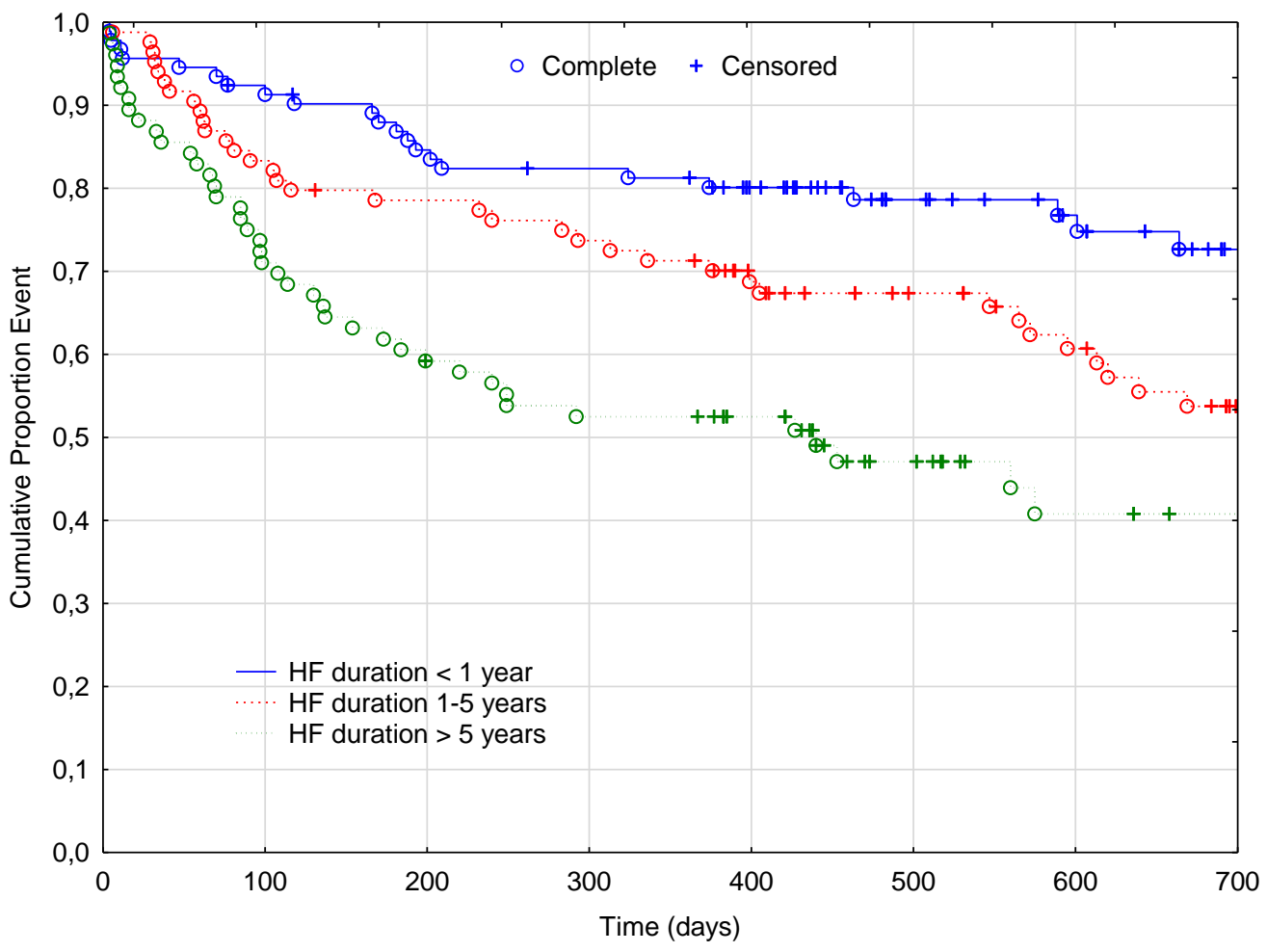

Patients at risk

\begin{tabular}{lllll}
\hline & O day & 200 days & 400 days & 600 days \\
\hline HF duration <1 year & 92 & 76 & 65 & 39 \\
HF duration 1-5 years & 84 & 65 & 51 & 36 \\
HF duration >5 years & 76 & 44 & 34 & 13 \\
\hline
\end{tabular}

Notes: HF:Heart failure. Censored participants were those still alive at study period or did not have a HF hospitalisation. Completed participants were those who had an event (mortality or HF hospitalisation) during the study period. 
To adjust for clinically important variables a multivariate Cox proportional hazard regression analysis for the three different HF durations was performed. In the multivariate model it could be demonstrated that in spite of other variables in the model, HF duration still provided significant and prognostic information (Table 10); between group 1 and group 2, HR 1.54; (95 \% Cl 0.91-2.60; $p<0.11)$, between group 2 and group 3, HR 1.59; (95\% Cl 1.01-2.50; $\mathrm{p}<0.04)$, and finally between group 1 and group 3, HR 1.65; (95 \% Cl 1.27-2.14; $\mathrm{p}<0.0002)$.

\section{Table 10.}

Multivariate Cox regression analysis of HF hospitalisations and mortality between group 1 (HF duration< 1 year), group 2 ( $H F$ duration $1-5$ years) and group 3 ( $H F$ duration $>5$ years).

Group 1 and 2

Group 1 and 3

Group 2 and 3

\begin{tabular}{llllllllll}
\hline & $\mathrm{HR}$ & $95 \% \mathrm{Cl}$ & $\mathrm{p}$-value & $\mathrm{HR}$ & $95 \% \mathrm{Cl}$ & $\mathrm{p}$-value & $\mathrm{HR}$ & $95 \% \mathrm{Cl}$ & $\mathrm{p}$-value \\
IHD & 1.45 & $0.81-2.63$ & 0.21 & 1.06 & $0.60-1.90$ & 0.41 & 1.48 & $0.85-2.61$ & 0.17 \\
Male gender & 0.95 & $0.56-1.72$ & 0.95 & 1.11 & $0.84-2.26$ & 0.56 & 0.72 & $0.44-1.16$ & 0.18 \\
Hypertension & 1.20 & $0.73-1.98$ & 0.48 & 1.38 & $0.84-2.26$ & 0.24 & 0.93 & $0.62-1.54$ & 0.93 \\
Diabetes mellitus & 1.53 & $0.90-2.59$ & 0.11 & 1.40 & $0.79-2.47$ & 0.24 & 1.12 & $0.71-1.80$ & 0.62 \\
Duration of HF & 1.54 & $0.91-2.60$ & 0.11 & 1.65 & $1.27-2.14$ & 0.0002 & 1.59 & $1.01-2.50$ & 0.04 \\
Age over/under 75 years & 1.46 & $0.88-2.41$ & 0.14 & 1.72 & $1.00-2.96$ & 0.05 & 1.16 & $0.73-1.84$ & 0.54
\end{tabular}

Notes: $\mathrm{Cl}=$ confidence interval upper and lower, $\mathrm{HF}=\mathrm{Heart}$ failure, $\mathrm{HR}=$ Hazard Ratio, $\mathrm{IHD}=\mathrm{Ischemic}$ heart disease. 


\section{Impact of age and duration of heart failure diagnosis on BNP concentration}

We also performed an analysis of the effect age had on BNP concentration with repeated measures of variance. In this evaluation age over and under 75 years showed a significant effect on BNP concentration, $(F=3.29 ; p=0.04)$.

\section{Figure 20.}

BNP concentrations for the three groups in different weeks during the study; group 1 HF duration less than one year, group 2 HF duration 1-5 years, and group 3 with HF duration more than five years. No significant differences in BNP concentrations could be seen at study start. Significant differences could be seen in week $16(p<0.02)$, in week $48(p<0.02)$ and at study end $(p<0.002)$ between the groups.

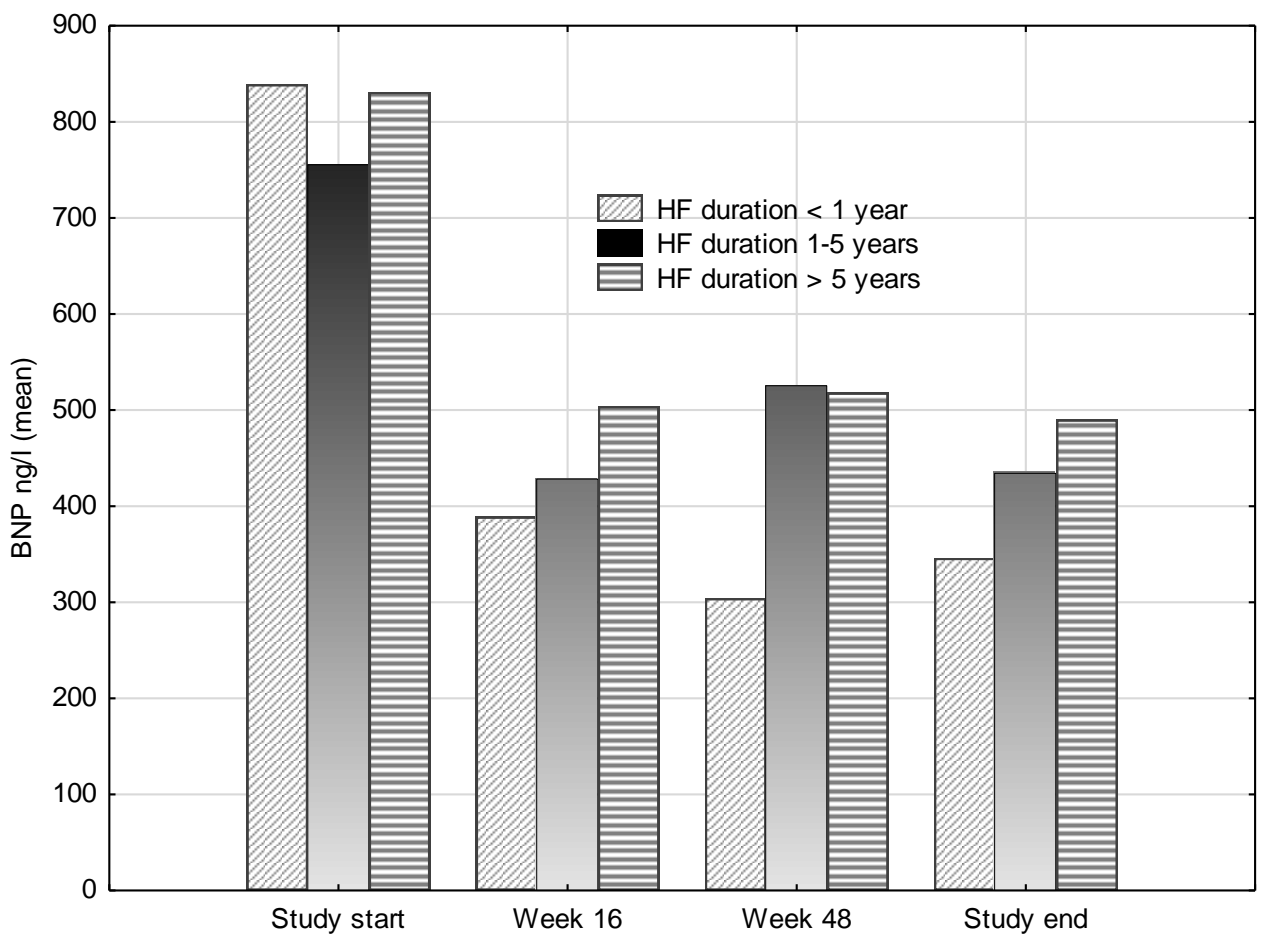


In figure 20, the mean values of the BNP concentration are presented at the study start, week 16, week 48 and at the study end for the three different HF duration groups. There were no significant differences in BNP concentrations between the three groups at the study start. However, at week 16 there were significant differences between the groups $\mathrm{P}<0.02$ and at the study end $\mathrm{P}<0.002$.

Repeated measures of variances were performed to explore the effect of HF duration and BNP with a focus on the individual changes in BNP. This evaluation showed a significant effect on BNP concentration when evaluated against HF duration less than one year compared to HF duration more than five years during BNP-guided HF treatment $(F=4.24 ; p<0.02)$ (Figure 21).

\section{Figure 21.}

Presentation of $\log ^{10}(B N P)$ at study start, at 16 weeks and at study end for patients with HF duration less than one year and with HF duration more than 5 years.

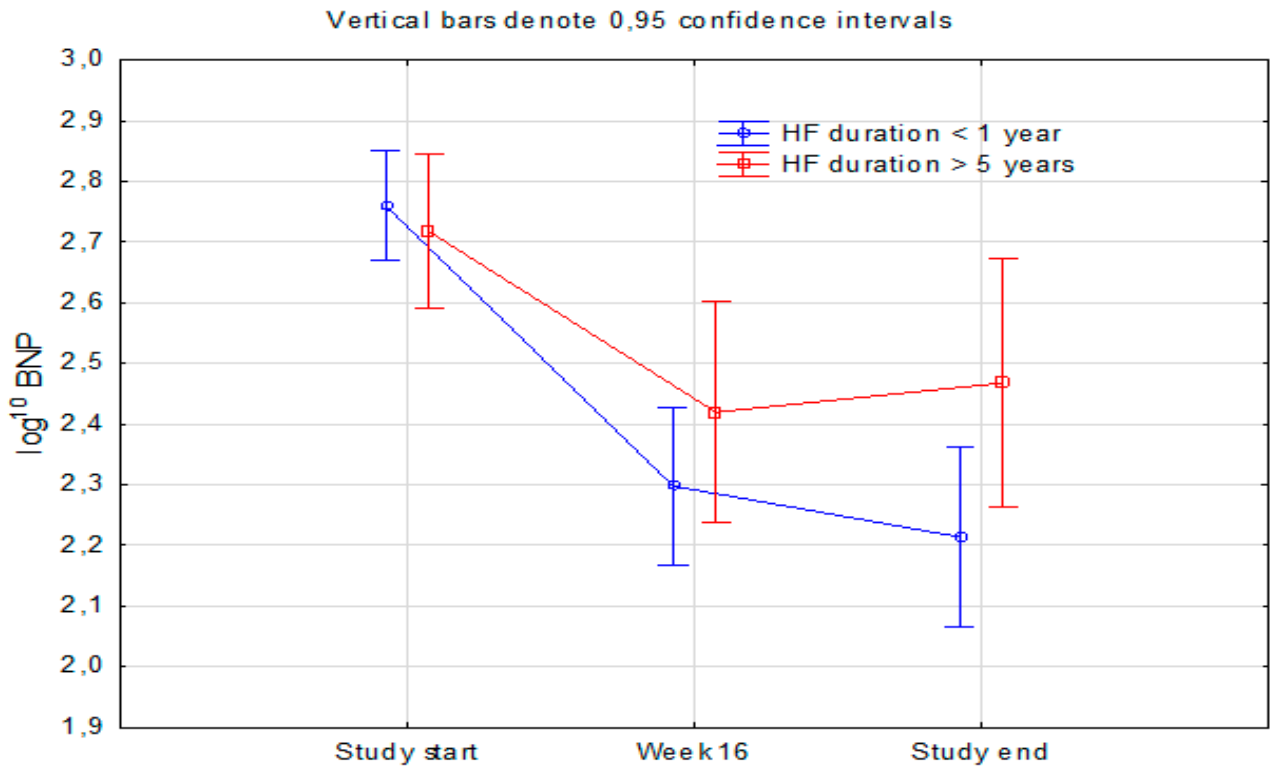


Page 88 


\section{DISCUSSION}

\section{NP-guided treatment in heart failure}

\section{The past}

When this study was designed there was only one study published on NP-guiding, by Troughton et al. in 2000 [163]. They showed that HF treatment guided by NT-proBNP resulted in fewer total cardiovascular events compared to the clinical group. The NTproBNP concentration that was used to guide was relatively high (NT-proBNP 200 $\mathrm{pmol} / / \approx 1700 \mathrm{ng} / \mathrm{l})$ and the study was small, with 69 patients. Therefore, the need for a larger study was obvious.

\section{The present}

The results in paper I showed no significant differences in outcome between the BNP-guided HF treatment group and the CTR group. However, as the p-value from the primary outcome variable was $p=0.18$ this might indicate that the study was underpowered. Based on the power analysis with the assumption of a follow-up of one year, but where a mean follow-up time of 649 days was applied, a new interim analysis was performed based on a follow-up of 250 days. The results revealed a difference between the two groups of 12 percent $(p=0.10)$ (Figure 22). A new post hoc power analysis was therefore performed including the above information. From that evaluation a sample size of 644 individuals (322 individuals per group) would demonstrate a significant difference between the BNP-guided group and the CTR 
group. From this it could be concluded that BNP-guiding could be beneficial but as the study was underpowered this could not be demonstrated.

\section{Figure 22.}

Kaplan-Meier graph of primary outcome variable for the BNP-guided group and the CTR group with a new interim analysis performed at follow-up after 250 days $(p=0.10)$.

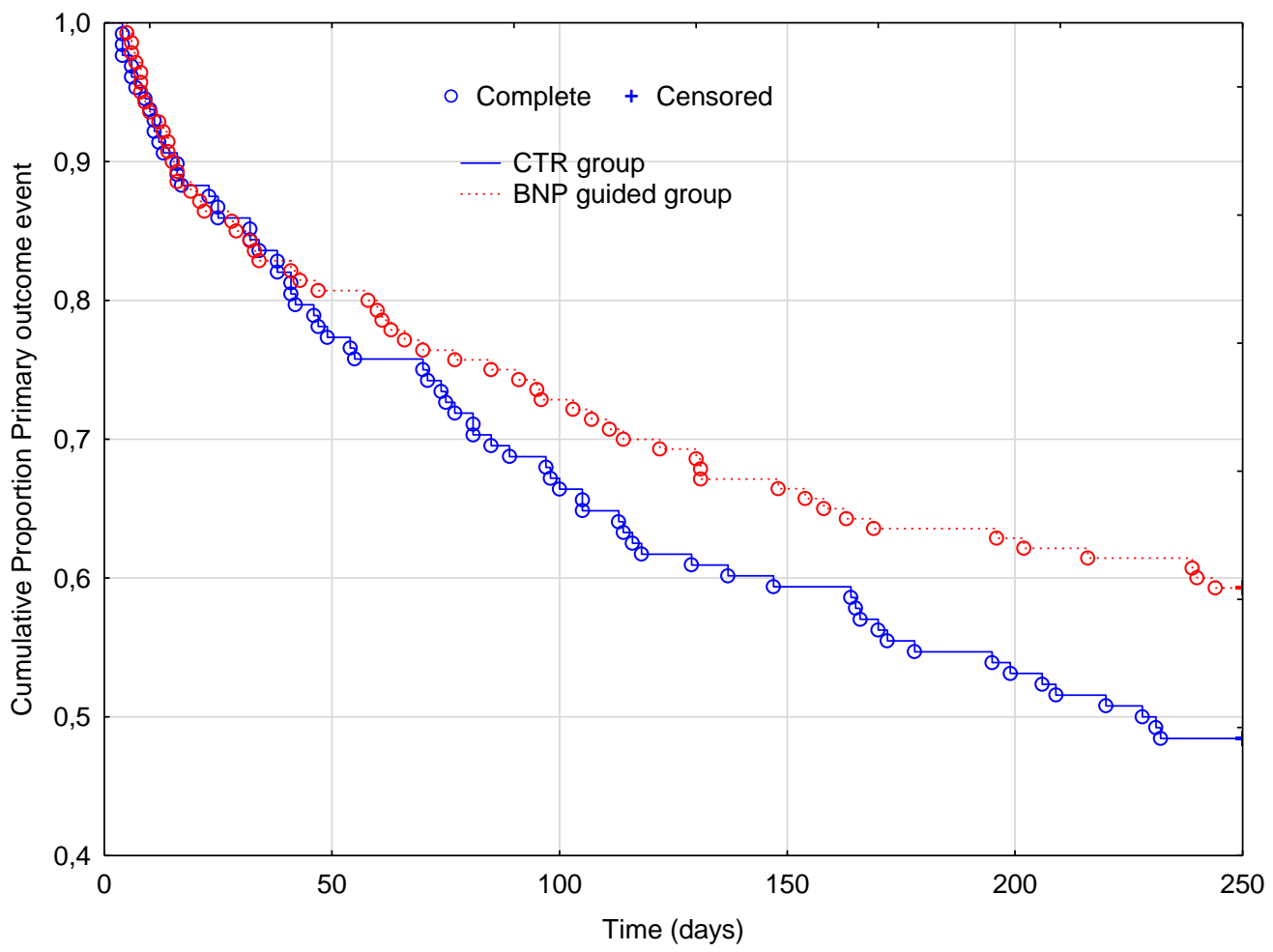

At present there are a total of 11 studies evaluating the benefits of NP-guiding. Of those, seven are neutral studies [190, 201-206] and four are positive [163, 207-209] regarding primary outcome. In the neutral studies the sample size varied between 60 to 499 participants, mean age varied between $60-78$ years and the NP-guiding target 
varied between three different levels. The target for BNP varied between $100 \mathrm{ng} / \mathrm{L}$ to $450 \mathrm{ng} / \mathrm{I}$ and NT-proBNP $400 \mathrm{ng} / \mathrm{l}$ to $1270 \mathrm{ng} / \mathrm{L}$. The third level was more difficult to generalize due to tailoring to individual NT-proBNP levels. In the positive studies the sample size varied between 69-220 participants, and mean age varied between 6371 years. The target for BNP was $100 \mathrm{ng} / \mathrm{L}$ and for NT-proBNP it was $1000 \mathrm{ng} / \mathrm{L}$ to $2200 \mathrm{ng} / \mathrm{L}$. Thus, there are several challenges when designing an NP-guiding study.

\section{Sample size}

Regarding sample size, the UPSTEP study can presently be regarded as one of the largest studies. In a meta-analysis including 2000 patients published by Troughton et al. 2014, the UPSTEP study contributed with 13 percent of the total patient population [210]. Other aspects than size such as age, NP cut-off level and medication obviously influence the chance of success in NP-guiding.

Age

In relation to the UPSTEP study the patients in the neutral studies were older and the patients in the positive studies were younger. Age has been discussed as an important factor that can influence the benefits of NP-guiding. In the meta-analysis by Troughton et al. patients older than 75 years had no survival benefit from NP-guiding, $\mathrm{p}=0.96$, whereas for those younger than 75 years there was a significant survival benefit, $p=0.004$ [210].

In contradiction to this, evaluation of the UPSTEP study in paper I showed no significant differences in age $<75$ years versus $>75$ years in the primary outcome 
variable. Furthermore, in paper IV we saw that age had no effect on the composite endpoint score. However, when dividing the population into tertiles according to HF duration we saw significant differences in outcome. We divided the HF duration into three groups: HF duration less than one year, 1-5 years, and more than five years. With this division there were influences on the outcome in HF mortality and HF hospitalisations. The influence of age on BNP showed an increased BNP concentration as age increased. This is in the line with data from Hogenhuis et al. that confirmed the positive relation between increasing BNP and increasing age in 311 patients with HF [211]. In conclusion, the benefits of NP-guiding will probably be influenced not only by the age of the patient but also by the age of the disease.

\section{NP-guiding values}

In paper I the HF treatment goal for BNP was $150 \mathrm{ng} / \mathrm{L}$ if the patient was younger than 75 years and $300 \mathrm{ng} / \mathrm{L}$ if the patient was older than 75 years. One reason for the different results in the NP-guiding studies might be that the target for HF treatment by NP concentrations has varied between the studies, and this might have influenced the outcome. Compared to paper I, two out of the four positive studies had low target NP levels; Systolic Heart Failure Treatment Supported by BNP (STARS-BNP) [208] had a BNP target of $100 \mathrm{ng} / \mathrm{L}$ and the PROTECT (Prospective, Randomized ProBNP Outpatient Tailored Chronic Heart Failure Therapy) study [209] had NT-proBNP 1000 $\mathrm{ng} / \mathrm{L}$ (approximately BNP $120 \mathrm{ng} / \mathrm{L}$ ) as the target level. However, the mean ages in these two studies were relatively low; 65 years and 63 years. In one of the two remaining positive studies by Berger et al. the dosage of RAAS at the study start was approximately 50 percent of the recommended dosage according to guidelines 
in all three groups (NP-guided, multidisciplinary care and usual care) [207]. At the study end, significantly more patients in the NP-guided group and the multidisciplinary group had a higher target dosage of RAAS than those in standard care. The mortality was only significantly higher in usual care compared to the two other groups. The percentage of the target dose for RAAS in usual care was 54 ( \pm 38$)$, and in NP-guided care it was $100( \pm 64)$, indicating that reaching the target dosage for HF medication according to guidelines affects outcome. The usual care group was not medicated according to guidelines. It is important to compare the NPguided $\mathrm{HF}$ treatment group with a control group that is on $\mathrm{HF}$ medication according to guidelines. Thus, it might be questioned if the positive result was driven by the NPguiding or the under treatment in the usual care group. The neutral studies generally have higher NP levels; STARBRITE (The Strategies for Tailoring Advanced Heart Failure Regimes in the Outpatient Setting) had BNP 450 ng/L as a HF treatment goal compared to STARS-BNP with a BNP $<100 \mathrm{ng} / \mathrm{L}$ as an $\mathrm{HF}$ treatment goal. In STARBRITE the treatment goal was individual and based on the discharge BNP value after hospitalisation for acute HF. In PRIMA (Can Pro-brain-natriuretic peptide guided therapy of chronic heart failure Improve heart fAilure morbidity and mortality) and SIGNAL-HF (Swedish Intervention study-Guidelines and NT-proBNP AnaLysis in Heart Failure) there were individual relatively high NP goals (Table 11). Therefore, at present it seems that a lower target level will increase the chance of successful NPguiding. 


\section{Medication}

Based on the currently published NP-guiding studies the initial medication when entering the trial differed considerably $[190,207]$. This most probably influenced the success of NP-guiding. In paper I, both groups were already on high doses of HF treatment at the study start. The doses were increased during the study but with no significant differences in doses of HF medication between the BNP-guided group and the CTR group [190] (Table 4). In the positive study STARS-BNP containing younger participants compared to our study population in paper I, there were no significant differences in medication between the BNP-guided group and the control group at baseline (94 percent were on the recommended daily dose of ACEi or ARB in both groups); however, after three months the mean dosages of ACEi (98 percent in the control group and 106 percent in the BNP-guided group) and BB were significantly higher in the BNP group [208]. During the three months the percentage of patients with a BNP under $100 \mathrm{ng} / \mathrm{L}$ doubled; from 15 percent to over 30 percent. In PRIMA an increased NT-proBNP value often prompted the physicians to intensify diuretic therapy [202], which might be an explanation for the neutral outcome in PRIMA. This illustrates the complexity of NP-guiding where gaining enough knowledge regarding whether the lowest possible NP value, or reaching the recommended treatment dose according to guidelines should be the primary target.

\section{Influence of heart failure management}

Interestingly, one reason for the negative trials in the NP-guiding area could be that the control group received the same intensity of HF management as the NP-guided group, thus a higher rate of contacts with health care professionals. The use of a 
nurse-led HF clinic improved HF outcome has previously been shown by Strömberg et al. [102]. A Dutch study randomly allocating HF patients to intensive HF care $(n=118)$ or standard care $(n=122)$ over 12 months showed a significant reduction in the number of admissions for worsening HF and/or all-cause deaths in the intervention group compared to standard care [212]. This demonstrates that there are more aspects influencing the outcome of NP-guiding than medication and NP values.

\section{The future}

There are many aspects to consider if NP-guided HF treatment is to be established in the future. The studies have to be adequately sized to compare NP-guided HF treatment and the control group. The control group must be treated with HF medication according to guidelines. The study must be adequately powered to answer the question of age. The question of the best target level for NP-guiding deserves clinical research.

New treatments might influence the use of present biomarkers in NP-guiding. One example of this could be the PARADIGM study (Prospective comparison of Angiotensin Receptor neprilysin inhibitors with Angiotensin-converting enzyme inhibitors to Determine Impact on Global Mortality and morbidity in Heart Failure). The neprilysin inhibitor sacubitril in combination with valsartan was tested against enalapril in patients with HF. Neprilysin, a neutral endopeptidase degrades natriuretic peptides and the inhibition increases the level of BNP [213]. The use of BNP for guiding HF therapy in the future will not be possible in patients on the new medication, so other biomarkers have to be used instead. 


\section{Table 11.}

All NP-guided studies and NT-proBNP and BNP values at study start according to meta-analysis by Troughton et al. [210]. HR-QoL instrument if available and if HR-QoL improved by NP-guiding.

\begin{tabular}{|c|c|c|c|c|c|}
\hline Study & $\begin{array}{l}\text { Age } \\
\text { years } \\
\text { (Mean } \\
\pm S D)\end{array}$ & $\begin{array}{l}\text { Target for NP } \\
\text { concentration }\end{array}$ & $\begin{array}{l}\text { NT-proBNP } \\
\text { (median) }\end{array}$ & $\begin{array}{l}\text { BNP ng/l } \\
\text { (median) }\end{array}$ & $\begin{array}{l}\text { HR-QOL instrument } \\
\text { (NP-guiding improved } \\
\text { HR-QoL compared to } \\
\text { control yes/no) }\end{array}$ \\
\hline \multicolumn{6}{|l|}{ Neutral studies } \\
\hline STARBRITE[201] & $60 \pm 16$ & $\begin{array}{l}\text { BNP at hospital } \\
\text { discharge } 450 \mathrm{ng} / \mathrm{l}\end{array}$ & & 453 & Not applicable \\
\hline UPSTEP[190] & $71 \pm 10$ & $\begin{array}{l}\text { If }<75 y . \\
B N P<150 \mathrm{ng} / \mathrm{l} \\
\text { If }>75 y . \\
B N P<300 \mathrm{ng} / \mathrm{l}\end{array}$ & & 608 & SF-36 (No) \\
\hline PRIMA[202] & $72 \pm 12$ & $\begin{array}{l}\text { Individual NP } \\
\text { levels at discharge }\end{array}$ & 2961 & & $M L w H F(N o)$ \\
\hline BATTLESCARRED[203] & $74 \pm 9$ & $\begin{array}{l}\text { NT-proBNP }<1270 \\
n g / l\end{array}$ & 2012 & & $M L w H F(N o)$ \\
\hline \multirow[t]{3}{*}{ TIME-CHF[204] } & $76 \pm 8$ & $\begin{array}{l}\text { If }<75 \text { y. NT- } \\
\text { proBNP }<400 \\
p g / m l\end{array}$ & 4194 & & $\begin{array}{l}\text { MLwHF (No) } \\
\text { SF-12(No) }\end{array}$ \\
\hline & & If $75 y$. & & & Duke activity status (No) \\
\hline & & $\begin{array}{l}\text { NT-proBNP }<800 \\
n g / l\end{array}$ & & & \\
\hline SIGNAL-HF[205] & $78 \pm 7$ & $\begin{array}{l}\text { NT-proBNP } 50 \% \\
\text { below baseline }\end{array}$ & 2362 & & $K C C Q(\mathrm{No})$ \\
\hline Anguita et al.[206] & $70 \pm 8$ & $B N P<100 \mathrm{ng} / \mathrm{l}$ & & 136 & Not applicable \\
\hline \multicolumn{6}{|l|}{ Positive studies } \\
\hline PROTECT[209] & $63 \pm 14$ & $\begin{array}{l}\text { NT-proBNP }<1000 \\
n g / l\end{array}$ & 2118 & & MLwHF (Yes) \\
\hline STARS-BNP[208] & $65 \pm 5$ & $B N P<100 \mathrm{ng} / \mathrm{l}$ & & 352 & Not applicable \\
\hline Berger et al.[207] & $71 \pm 12$ & $\begin{array}{l}N T-p r o B N P<2200 \\
n g / l\end{array}$ & 2280 & & Not applicable \\
\hline Troughton et al.[163] & $70 \pm 10$ & $\begin{array}{l}N T \text {-proBNP }<1700 \\
n g / l\end{array}$ & 1980 & & $M L w H F(N o)$ \\
\hline
\end{tabular}

Notes: BNP, B-type Natriuretic Peptide, NT-proBNP, N-terminal pro-B-type natriuretic peptide, KCCQ, Kansas City Cardiomyopathies Questionnaire, MLwHF, Minnesota Living with Heart Failure, SF-12 Short Form 12, SF-36, Short Form 36, y. years. 


\section{Responder to BNP-guiding}

\section{The past}

When the UPSTEP study was planned there was no definition of a responder to BNP-guided HF treatment. In a study published in 2004 by Bettencourt et al. the 182 patients hospitalized because of decompensated HF were divided into three groups depending on changes in NT-proBNP during the hospitalisation [148]. Patients with a decrease in NT-proBNP of at least 30 percent during the hospitalisation had significantly fewer readmissions and less mortality during follow-up. However, the responder concept in NP-guiding was not introduced until 2009, by Cohen-Solal et al. [214]. Therefore, we designed a post hoc analysis to evaluate the NP-guiding responder concept.

\section{The present}

There is growing knowledge supporting the utility of NP in testing for risk stratification among patients with heart failure and even in patients without HF [215]. This is important since if NP concentration does not decrease despite intensive HF treatment and HF care there is an increased risk of mortality and hospitalisation [8]. In paper I a responder to HF treatment was predefined as a patient showing a decrease in BNP of at least 30 percent, the same level as used by Bettencourt et al. [143] in week 48 compared to study start. In paper I an increased risk could be demonstrated within the non-responders regarding CV mortality and hospitalisation. Our results are corroborated by the findings by Bettencourt et al. Also, a retrospective analysis of Cohen-Solal et al. showed that in patients hospitalised with acute HF a 
reduction in BNP of at least 30 percent led to better outcome than found for patients without a corresponding response [214]. In the Val-HeFT trial, Anand et al. in 2003 showed that in an outpatient setting a decrease in BNP during follow-up was associated with lower mortality [145]. However, to our knowledge there is no scientific evidence that 30 percent is the optimal cut-off value.

In paper II we therefore sought to explore the optimal week during follow-up and the optimal percentage change in BNP to apply to the definition of a responder. Based on the multitude of evaluations of different cut-off levels and times (weeks) a responder was a defined as a patient with a decrease of BNP of at least 40 percent and/or a $\mathrm{BNP}<300 \mathrm{ng} / \mathrm{l}$. Using an absolute model in their definition of a responder Gaggin et al. in 2013 defined a responder as a patient achieving NT-proBNP $\leq 1000$ $\mathrm{ng} / \mathrm{l}$, during the 10 months of follow-up under the HF therapy intervention [199]. With this definition Gaggin et al. showed that the responders had significantly fewer CV events [199]. The model used in paper II, the percentage model (i.e. 40 percent reduction and/or $\mathrm{BNP}<300 \mathrm{ng} / \mathrm{l}$ in week 16), was compared to the absolute model introduced by Gaggin et al. The result showed that the percentage model was at least not inferior to the absolute model ad modum Gaggin. The non-responder populations in paper II and the study by Gaggin et al. were both older compared to the responder population.

In the BATTLESCARRED trial (NT-proBNP-assisted Treatment To Lessen Serial Cardiac Re-admission and Death trial) [203] and TIME-CHF (The trial of Intensified vs. Standard Medical Therapy in Elderly Patients with Congestive Heart Failure) [204] patients younger than 75 had a better outcome when HF treatment was guided by NP. A greater proportion of the older population were non-responders, and this corresponded to non-responders in paper II who had a mean age of 74 . However, 
there were non-responders in the younger population. Elderly patients and nonresponders might therefore need a different management and strategies.

\section{The future}

Based on the obtained results described above there is a need for development and evaluation of treatment strategies tailored to responders and non-responders.

Therefore, regarding the responders there is a relatively low risk for $\mathrm{CV}$ complications, so the consequence might be less intense follow-up strategies compared to non-responders. It could also be expected that new biomarkers, such as Chromogranin A [216], copeptin [217], mid-regional pro-adrenomedullin (MRproADM) [218], Galectin-3 [219], and ST-2 [219] might be introduced into the clinical routine. This might increase the chances of pinpointing responders and allow HF treatment to be tailored with biomarkers. 


\section{BNP-guiding and Health-related quality of life}

\section{The past}

In previous NP-guiding studies, HR-QoL aspects have rarely been evaluated. When this study was designed, only one study by Troughton et al. had evaluated the impact of NP-guiding on HR-QoL without any effect [163]. When evaluating new treatment and management of HF the focus has been on mortality and morbidity; however, the importance of using patient-reported outcomes has been emphasized [180, 181]. Thus, the impact of NP-guiding on HR-QoL was at that time the study was designed unknown.

\section{The present}

At present the impact of NP-guiding on Hr-QoL has been evaluated in six other NPguiding studies (Table 11). Only one study has shown an improvement in HR-QoL in the NP-guided group compared to conventional HF treatment [220] and in five studies the results have been neutral [163, 202-205]. In the neutral studies the sample size varied between 69-499 participants and the mean age was between 7078 years. Only one of these studies used both a generic (SF-12) and disease-specific instrument (MLwHF) [204] and the other four used only disease-specific instruments. In the positive study the sample size was 151 participants and the mean age was 63, and a disease-specific instrument was used [220].

In paper III our evaluation of HR-QoL showed that the BNP-guided group improved in four domains and the CTR group improved in six domains. However, there was no significant difference between the two groups. The population in the positive study [220] was younger compared to the population in paper III with an average age of 71 . Thus, coincides with the five neutral studies with a mean age of 70-78 years. Older 
age could be a factor explaining the lack of benefit of BNP-guiding regarding HRQoL. Generally, younger HF patients have poorer HR-QoL compared to elderly HF patients [172, 221]. In elderly patients, other comorbidities than HF might also influence the perceived HR-QoL [177, 222]. This fact makes the margin to influence HR-QoL smaller as the study population is older.

Moreover, the population in paper III also seem to have had more severe HF compared to the population in the positive study. We converted our BNP value into an estimated NT-proBNP level. We found that the population in paper III had higher levels of NT-proBNP levels compared to the population in the positive study [220]. This indicates that the population in paper III had a more severe HF compared to the positive population; this, combined with older age and longer follow-up might make the population in paper III less likely to have benefitted from NP-guiding with improvement in HR-QoL. However, in a normative Swedish population Sullivan et al. show that the scores in SF-36 decrease in all eight domains with increasing age [223]. Despite the expected decrease in SF-36 scores we saw an increase during the almost two years of follow-up in paper III in both study groups, suggesting that effects on HR-QoL of participating in a study is a result apart from titration of medication such as frequent follow-ups.

\section{Responders and HR-QoL}

In paper III we also evaluated responders to NP-guiding with regard to HR-QoL.

Surprisingly, paper III showed no differences between responders and nonresponders. But the responders showed significant improvement in four domains whereas the non-responders improved significantly in one domain in the SF-36. 
The fact that BNP changes cannot be directly transferred into HR-QoL suggests that the perceived HR-QoL is a complex mechanism and other factors might influence the outcome (Figure 6). Thus paper III and other studies suggest that a decrease in BNP concentration does not automatically improve HR-QoL, and BNP-guiding in this respect seems to have a limited impact on HR-QoL. Figure 6 shows that the mechanisms behind perceived QoL are multifaceted, thus a decrease in BNP concentration may not automatically influence HR-QoL. Other studies also suggest a weak association between the biomarker concentration and HR-QoL [224].

Another important reason for the neutral result in paper III could be that all four groups received HF treatment according to guidelines, thus limiting the effect of BNPguiding on HR-QoL. As previously discussed, one reason for the neutral trials of the HR-QoL in the NP-guiding area could be that the control group received the same intensity of HF management as the NP-guided group, thus it had a higher rate of contact with health care professionals. In paper III, all patients had scheduled visits at weeks $2,6,10,16,24,36,48$ and then every six months until the study end, at the visits they met the HF nurses/doctors at the HF clinic. Support from health care professionals has been found to be an important factor influencing HF patients' HRQoL [225]. The CTR group had more events and thus met health care professionals more often. Such meetings positively influence the perceived HR-QoL in patients, as has been reported in an outpatient setting in primary health care [226, 227].

Health-related quality of life and BNP-guiding and HR-QoL instruments In paper III, HR-QoL was evaluated with the generic instrument SF-36 at the study start and at the study end. HR-QoL improved for all patients irrespective of whether 
they were in the NP-guided or the conventional HF treatment group. In the positive study, a disease-specific HR-QoL instrument was used. The advantage of a generic HR-QoL instrument is the increased ability to detect small changes in HF symptoms [165]. However, in the five neutral studies a disease-specific instrument was also used [163, 202-205]. This suggests that other factors, such as age, can be of importance besides the choice between generic or disease-specific HR-QoL instrument. Moreover, there are studies indicating that SF-36 is better for differentiating physical and emotional aspects of HR-QoL compared to the diseasespecific instrument MLwHF [189].

\section{The future}

It has been recognized that measuring HR-QoL is important when introducing new concepts in CV medicine [180,181]. To increase the ability to identify changes in perceived HR-QoL it might be an advantage to use both types of instruments (generic and disease-specific). Generic health status surveys quantify well-being and functional status but do not address functional limitations and symptoms attributable to HF disease. The combination of generic and disease-specific instruments makes it possible to compare the results with other studies on $\mathrm{HF}$ and also with a normative population and patients with other diseases.

\section{Methodological considerations}

When evaluating the outcome there were 88 events in the conventionally treated group and 85 events in the BNP-guided group. In the power analysis the conditions 
in the outcome were a 50 percent reduction in the BNP-guided group compared to conventional treated group, indicating that a type II error cannot be excluded. Retrospectively, the study was underpowered, which probably influenced the result. Another potential problem might be the inclusion of elderly participants as they were probably suffering more comorbidities compared to younger persons and were less likely to benefit from NP-guiding [228]. As the mean age of the HF population in the community is more than 75 it might be problematic to generalize these aspects.

In paper I both the BNP group and the control group were on the target dosage according to guidelines at the study start. There were no significant differences in dosage between the groups during the study. This reduces the possibility of differentiating the HF treatment between the groups with BNP-guiding. In the UPSTEP study no measurements of BNP were performed in the control group during the intervention. Therefore, by measuring BNP in the control group a significant increase in the information on NP-guiding response could be gained. The design of the UPSTEP study resulted in more frequent contact with health care professionals for the control group compared to clinical routine. This probably resulted in a more intense titration of $\mathrm{HF}$ medication.

A logical further step to increase the pathophysiological information about the response to NP-guiding would be to include biomarkers reflecting different aspects of the HF. One potential candidate could be the extra cardiac biomarker Copeptin [217]. 


\section{Ethical considerations}

As this is an elderly and fragile population the NP-guided therapy might introduce adverse reactions or side effects such as dizziness, hypotension and renal impairment. As all patients in the NP-guiding group had frequent contact and followup visits with specialized HF nurses and HF doctors, such side effects could be detected early. Moreover, no patients dropped out due to side effects. BNP-guiding introduces a more frequent blood sample test which might be considered burdensome and painful for the patient. Taking into consideration the potential benefit of BNP-guiding this was regarded as a minor problem and no patient dropped out due to this. Finally, the frequent follow-ups result in more frequent trips to the hospital and therefore increased cost, and this might be regarded as burdensome for the participants. However, as reported through the HR-QoL this obviously was not a negative factor.

\section{Clinical implications}

From the presented data it could be seen that the duration of HF is an underestimated factor and may be more important than age when considering the success of treatment of HF. Tailoring the HF treatment by NP-guiding is intuitively probably a more accurate way to interpret HF and the response to treatment compared to just a clinical evaluation. Moreover, demonstrating the biomarker response to treatment for the patient might increase the adherence to treatment. By identifying non-responders, patients at high risk might be identified and could be 
considered for more intense HF handling. However, the definition of a responder has still not been elucidated. Natriuretic peptide testing is regarded as a routine blood sample test with a fairly low cost, influencing its ability to be used in the handling of HF patients. However, based on the present literature, tailoring the HF treatment through NP-guiding has not yet been convincingly demonstrated to be positive in the clinical routine and therefore more research is needed.

\section{Future research}

In a future biomarker study aimed to guide HF treatment the biomarker concentration should be targeted low and should be adjusted to age and disease duration.

The intensity of pre-study medication has to be considered when designing a new study. A potential problem is the design of the handling of the control group, as we have discussed previously.

The definition of a responder needs to be established. The therapeutic consequences for the identified non-responders have to be investigated.

In future studies the impact of NP-guiding on symptoms, physical and psychological limitations, HR-QoL and finally health economy have to be evaluated (Figure 6). 


\section{CONCLUSIONS}

- The benefit of BNP-guided HF treatment was not sufficiently demonstrated to improve outcome compared to conventional HF treatment.

- Age of the patient, the target NP level and pre-study HF medication may influence the success of NP-guiding.

- Responders to NP-guiding HF treatment had better outcome than nonresponders.

- HR-QoL improved both in the BNP-guided and in the control group. No clear benefit of NP-guiding on HR-QoL was demonstrated.

- Both the responders and non-responders improved their HR-QoL.

- Patients with short HF duration had better outcome compared to patients with longer HF duration.

- Age itself did not influence outcome but age had an impact on BNP concentration.

- BNP concentration increased as HF duration increased, even when adjusted for age. 


\section{ACKNOWLEDGEMENTS}

I would like to express my sincere gratitude and appreciation to everyone who contributed to my work. In particular I would like to thank the following persons:

All patients that participated in the UPSTEP study.

Ulf Dahlström, professor at the Department of Cardiology, Linköping for initiating the UPTEP study and for giving me the opportunity to pursue research and guidance during my research.

Urban Alehagen, associate professor at the Department of Cardiology, Linköping. My main tutor, for introducing me to the field of research and then assisted me throughout this thesis in an ideal way and with never-ending energy. Thank you for believing in me and pushing me.

Peter Johansson, associate professor at the Department of Cardiology, Linköping, for sharing your expertise in the field of "quality of life" and all inspiring discussions.

Kurt Boman, professor at the Department of Medicine, Skellefteå for initiating the UPSTEP study.

Research nurses in the UPSTEP study: Anette Gylling, Malin Huss, Kerstin Gustavsson Department of Cardiology, Linköping and Mona Olofsson Department of Medicine \& Geriatrics, Skellefteå.

Ingela Nyrinder, heart failure nurse, for all help with the UPSTEP study in Jönköping. 
UPSTEP investigators in Norway: Björn Arild Halvorsen, Moss Hospital, Tomas von den Luederer, Akers University Hospital, Torstein Hole, Ålesund Hospital, Ellinor Aase, Bearum Hospital.

UPSTEP investigators in Sweden: Kurt Boman, Skellefteå County Hospital, Ulf Dahlström \& Urban Alehagen, Linköping University Hospital, Patric Karlström, Jönköping County Hospital, Lars-Erik Larsson, Västervik Hospital, Bo Wikström Kalix Hospital, Anders Ehnberg, Strömsund, Diana Ticic, Örebro University Hospital, Åsa Karlsson, Motala Hospital, Kristian Waern Bugge, Nyköping Hospital, Jan Sörbo, Alingsås Hospital, Anette Sandström, Lycksele Hospital, Märit Mejhert, Ersta Hospital Stockholm, Inger Hagerman, Karolinska University Hospital, Huddinge, Claes Ringqvist, Sundsvall Hospital.

Endpoint committee in the UPSTEP study: Olof Svensson (Jönköping) and KarlAnders Jacobsson (Umeå).

Professor Lena Jonasson, Associate Professor Lennart Nilsson and Associate Professor Håkan Walfridsson, Department of Medical and Health Sciences, Linköping for valuable input at "half-time".

The Regional Research Foundation in south-eastern Sweden and the Regional Research Foundation in northern Sweden funded the study. The Swedish Heart-lung foundation for financial funding.

Futurum-the Academy of Health-care, Jönköping County Council, for financial funding.

Jan-Erik Karlsson, associate professor at the Department of Internal Medicine, Jönköping, who got me interested in research. 
All my colleagues at the Cardiology Department patiently endured an increased work load during my absence.

Fellow colleagues, nurses, staff and managers at the Department of Internal Medicine, Ryhov County Hospital, Jönköping for creating a friendly atmosphere and showing interest in my research.

Klara Fridh for computer assistants and knowledge of computer programming.

Richard Källberg for all help with computers and programmes.

Linnea Fridh for introducing me to Word and Excel.

Eva-Marie Ebefors for the help with the flow charts.

Albin Fridh for help with mathematical solutions and help with linguistic difficulties.

Andreas Ahlstrand for constructive criticism, fruitful discussions and being a good friend.

Jörg Lauermann for friendship and encouragement.

Till slut, ett varmt tack till:

mina föräldrar, som alltid visat att allt är möjligt.

mina älskade barn, Linnea, Albin och Klara. Nu kommer jag upp ur källaren.

min älskade hustru Ingrid. Du ger mig livskvalitet och sluter cirkeln. 


\section{REFERENCES}

1. Saba, M.M., et al., Ancient Egyptian medicine and the concept of heart failure. J Card Fail, 2006. 12(6): p. 416-21.

2. Katz, A.M., The "modern" view of heart failure: how did we get here? Circ Heart Fail, 2008. 1(1): p. 63-71.

3. Ross, P.H. and S. Grau, Massive response to a mercurial diuretic in a case of congestive heart failure. Ann Intern Med, 1950. 32(2): p. 335-8.

4. Davis, R.C., F.D. Hobbs, and G.Y. Lip, ABC of heart failure. History and epidemiology. BMJ, 2000. 320(7226): p. 39-42.

5. Evidence-Based Medicine Working, G., Evidence-based medicine. A new approach to teaching the practice of medicine. JAMA, 1992. 268(17): p. 24205.

6. Effects of enalapril on mortality in severe congestive heart failure. Results of the Cooperative North Scandinavian Enalapril Survival Study (CONSENSUS). The CONSENSUS Trial Study Group. N Engl J Med, 1987. 316(23): p. 142935.

7. McMurray, J.J., et al., ESC guidelines for the diagnosis and treatment of acute and chronic heart failure 2012: The Task Force for the Diagnosis and Treatment of Acute and Chronic Heart Failure 2012 of the European Society of Cardiology. Developed in collaboration with the Heart Failure Association (HFA) of the ESC. Eur J Heart Fail, 2012. 14(8): p. 803-69.

8. Yancy, C.W., et al., 2013 ACCF/AHA guideline for the management of heart failure: a report of the American College of Cardiology Foundation/American Heart Association Task Force on Practice Guidelines. J Am Coll Cardiol, 2013. 62(16): p. e147-239.

9. McMurray, J.J. and S. Stewart, Epidemiology, aetiology, and prognosis of heart failure. Heart, 2000. 83(5): p. 596-602.

10. Hobbs, F.D., et al., Impact of heart failure and left ventricular systolic dysfunction on quality of life: a cross-sectional study comparing common chronic cardiac and medical disorders and a representative adult population. Eur Heart J, 2002. 23(23): p. 1867-76.

11. Zarrinkoub, R., et al., The epidemiology of heart failure, based on data for 2.1 million inhabitants in Sweden. Eur J Heart Fail, 2013. 15(9): p. 995-1002.

12. Ryden-Bergsten, T. and F. Andersson, The health care costs of heart failure in Sweden. J Intern Med, 1999. 246(3): p. 275-84.

13. Stewart, S., et al., The current cost of heart failure to the National Health Service in the UK. Eur J Heart Fail, 2002. 4(3): p. 361-71.

14. Agvall, B., et al., Cost of heart failure in Swedish primary healthcare. Scand J Prim Health Care, 2005. 23(4): p. 227-32.

15. Cleland, J.G., et al., The EuroHeart Failure survey programme-- a survey on the quality of care among patients with heart failure in Europe. Part 1: patient characteristics and diagnosis. Eur Heart J, 2003. 24(5): p. 442-63.

16. Dunlay, S.M., et al., Lifetime costs of medical care after heart failure diagnosis. Circ Cardiovasc Qual Outcomes, 2011. 4(1): p. 68-75.

17. Mosterd, A. and A.W. Hoes, Clinical epidemiology of heart failure. Heart, 2007. 93(9): p. 1137-46.

18. Braunwald, E., Heart failure. JACC Heart Fail, 2013. 1(1): p. 1-20. 
19. Ho, K.K., et al., Survival after the onset of congestive heart failure in Framingham Heart Study subjects. Circulation, 1993. 88(1): p. 107-15.

20. Kupari, M., et al., Congestive heart failure in old age: prevalence, mechanisms and 4-year prognosis in the Helsinki Ageing Study. J Intern Med, 1997. 241(5): p. 387-94.

21. Fox, K.F., et al., Coronary artery disease as the cause of incident heart failure in the population. Eur Heart J, 2001. 22(3): p. 228-36.

22. Levy, D., et al., The progression from hypertension to congestive heart failure. JAMA, 1996. 275(20): p. 1557-62.

23. Kannel, W.B., Incidence and epidemiology of heart failure. Heart Fail Rev, 2000. 5(2): p. 167-73.

24. Cowie, M.R., et al., Incidence and aetiology of heart failure; a populationbased study. Eur Heart J, 1999. 20(6): p. 421-8.

25. Maisel, W.H. and L.W. Stevenson, Atrial fibrillation in heart failure: epidemiology, pathophysiology, and rationale for therapy. Am J Cardiol, 2003. 91(6A): p. 2D-8D.

26. McKee, P.A., et al., The natural history of congestive heart failure: the Framingham study. N Engl J Med, 1971. 285(26): p. 1441-6.

27. Eriksson, H., et al., Risk factors for heart failure in the general population: the study of men born in 1913. Eur Heart J, 1989. 10(7): p. 647-56.

28. Nieminen, M.S., et al., EuroHeart Failure Survey II (EHFS II): a survey on hospitalized acute heart failure patients: description of population. Eur Heart J, 2006. 27(22): p. 2725-36.

29. Cohn, J.N., R. Ferrari, and N. Sharpe, Cardiac remodeling--concepts and clinical implications: a consensus paper from an international forum on cardiac remodeling. Behalf of an International Forum on Cardiac Remodeling. J Am Coll Cardiol, 2000. 35(3): p. 569-82.

30. Opie, L.H., et al., Controversies in ventricular remodelling. Lancet, 2006. 367(9507): p. 356-67.

31. Heusch, G., et al., Cardiovascular remodelling in coronary artery disease and heart failure. Lancet, 2014. 383(9932): p. 1933-43.

32. Eaton, L.W., et al., Regional cardiac dilatation after acute myocardial infarction: recognition by two-dimensional echocardiography. $\mathrm{N}$ Engl J Med, 1979. 300(2): p. 57-62.

33. McKay, R.G., et al., Left ventricular remodeling after myocardial infarction: a corollary to infarct expansion. Circulation, 1986. 74(4): p. 693-702.

34. Erlebacher, J.A., et al., Late effects of acute infarct dilation on heart size: a two dimensional echocardiographic study. Am J Cardiol, 1982. 49(5): p. 1120-6.

35. Braunwald, E. and M.A. Pfeffer, Ventricular enlargement and remodeling following acute myocardial infarction: mechanisms and management. Am J Cardiol, 1991. 68(14): p. 1D-6D.

36. Kehat, I. and J.D. Molkentin, Molecular pathways underlying cardiac remodeling during pathophysiological stimulation. Circulation, 2010. 122(25): p. 2727-35.

37. Konstam, M.A., et al., Effects of the angiotensin converting enzyme inhibitor enalapril on the long-term progression of left ventricular dysfunction in patients with heart failure. SOLVD Investigators. Circulation, 1992. 86(2): p. 431-8.

38. Konstam, M.A., et al., Effects of the angiotensin converting enzyme inhibitor enalapril on the long-term progression of left ventricular dilatation in patients 
with asymptomatic systolic dysfunction. SOLVD (Studies of Left Ventricular Dysfunction) Investigators. Circulation, 1993. 88(5 Pt 1): p. 2277-83.

39. Greenberg, B., et al., Effects of long-term enalapril therapy on cardiac structure and function in patients with left ventricular dysfunction. Results of the SOLVD echocardiography substudy. Circulation, 1995. 91(10): p. 2573-81.

40. Doughty, R.N., et al., Left ventricular remodeling with carvedilol in patients with congestive heart failure due to ischemic heart disease. Australia-New Zealand Heart Failure Research Collaborative Group. J Am Coll Cardiol, 1997. 29(5): p. 1060-6.

41. Groenning, B.A., et al., Antiremodeling effects on the left ventricle during betablockade with metoprolol in the treatment of chronic heart failure. J Am Coll Cardiol, 2000. 36(7): p. 2072-80.

42. Tsutsumi, Y., et al., Angiotensin II type 2 receptor overexpression activates the vascular kinin system and causes vasodilation. J Clin Invest, 1999. 104(7): p. 925-35.

43. Hackenthal, E., et al., Morphology, physiology, and molecular biology of renin secretion. Physiol Rev, 1990. 70(4): p. 1067-116.

44. Fyhrquist, F. and O. Saijonmaa, Renin-angiotensin system revisited. J Intern Med, 2008. 264(3): p. 224-36.

45. Baker, K.M., G.W. Booz, and D.E. Dostal, Cardiac actions of angiotensin II: Role of an intracardiac renin-angiotensin system. Annu Rev Physiol, 1992. 54: p. 227-41.

46. Nakamura, K., et al., Inhibitory effects of antioxidants on neonatal rat cardiac myocyte hypertrophy induced by tumor necrosis factor-alpha and angiotensin II. Circulation, 1998. 98(8): p. 794-9.

47. Weber, K.T. and C.G. Brilla, Pathological hypertrophy and cardiac interstitium. Fibrosis and renin-angiotensin-aldosterone system. Circulation, 1991. 83(6): p. 1849-65.

48. Mizuno, Y., et al., Aldosterone production is activated in failing ventricle in humans. Circulation, 2001. 103(1): p. 72-7.

49. Ouvrard-Pascaud, A., et al., Conditional mineralocorticoid receptor expression in the heart leads to life-threatening arrhythmias. Circulation, 2005. 111(23): p. 3025-33.

50. Lijnen, P. and V. Petrov, Induction of cardiac fibrosis by aldosterone. J Mol Cell Cardiol, 2000. 32(6): p. 865-79.

51. Fullerton, M.J. and J.W. Funder, Aldosterone and cardiac fibrosis: in vitro studies. Cardiovasc Res, 1994. 28(12): p. 1863-7.

52. Kuster, G.M., et al., Mineralocorticoid receptor inhibition ameliorates the transition to myocardial failure and decreases oxidative stress and inflammation in mice with chronic pressure overload. Circulation, 2005. 111(4): p. 420-7.

53. Davie, A.P., et al., Assessing diagnosis in heart failure: which features are any use? QJM, 1997. 90(5): p. 335-9.

54. Mant, J., et al., Systematic review and individual patient data meta-analysis of diagnosis of heart failure, with modelling of implications of different diagnostic strategies in primary care. Health Technol Assess, 2009. 13(32): p. 1-207, iii.

55. Oudejans, I., et al., Clinical evaluation of geriatric outpatients with suspected heart failure: value of symptoms, signs, and additional tests. Eur J Heart Fail, 2011. 13(5): p. 518-27. 
56. Kelder, J.C., et al., The diagnostic value of physical examination and additional testing in primary care patients with suspected heart failure. Circulation, 2011. 124(25): p. 2865-73.

57. Khunti, K., et al., Accuracy of a 12-lead electrocardiogram in screening patients with suspected heart failure for open access echocardiography: a systematic review and meta-analysis. Eur J Heart Fail, 2004. 6(5): p. 571-6.

58. Madias, J.E., Why recording of an electrocardiogram should be required in every inpatient and outpatient encounter of patients with heart failure. Pacing Clin Electrophysiol, 2011. 34(8): p. 963-7.

59. Curtis, J.P., et al., The association of left ventricular ejection fraction, mortality, and cause of death in stable outpatients with heart failure. J Am Coll Cardiol, 2003. 42(4): p. 736-42.

60. Lang, R.M., et al., Recommendations for chamber quantification. Eur J Echocardiogr, 2006. 7(2): p. 79-108.

61. Quinones, M.A., et al., A new, simplified and accurate method for determining ejection fraction with two-dimensional echocardiography. Circulation, 1981. 64(4): p. 744-53.

62. Chatterjee, K. and B. Massie, Systolic and diastolic heart failure: differences and similarities. J Card Fail, 2007. 13(7): p. 569-76.

63. Paulus, W.J., How to diagnose diastolic heart failure: a consensus statement on the diagnosis of heart failure with normal left ventricular ejection fraction by the Heart Failure and Echocardiography Associations of the European Society of Cardiology. Eur. Heart J., 2007. 28: p. 2539-2550.

64. Vasan, R.S. and D. Levy, Defining diastolic heart failure: a call for standardized diagnostic criteria. Circulation, 2000. 101(17): p. 2118-21.

65. Effect of enalapril on survival in patients with reduced left ventricular ejection fractions and congestive heart failure. The SOLVD Investigators. N Engl J Med, 1991. 325(5): p. 293-302.

66. Effect of ramipril on mortality and morbidity of survivors of acute myocardial infarction with clinical evidence of heart failure. The Acute Infarction Ramipril Efficacy (AIRE) Study Investigators. Lancet, 1993. 342(8875): p. 821-8.

67. Re, R.N., Tissue renin angiotensin systems. Med Clin North Am, 2004. 88(1): p. 19-38.

68. Dunlap, M.E. and R.C. Peterson, ACE inhibitors vs ARBs: is one class better for heart failure. Cleve Clin J Med, 2002. 69(5): p. 433-8.

69. Harris, P., Congestive cardiac failure: central role of the arterial blood pressure. Br Heart J, 1987. 58(3): p. 190-203.

70. Tan, L.B., S.G. Williams, and D.F. Goldspink, From CONSENSUS to CHARM-how do ACEI and ARB produce clinical benefits in CHF? Int J Cardiol, 2004. 94(2-3): p. 137-41.

71. Sander, G.E., et al., Angiotensin-converting enzyme inhibitors and angiotensin II receptor antagonists in the treatment of heart failure caused by left ventricular systolic dysfunction. Prog Cardiovasc Dis, 1999. 41(4): p. 265-300.

72. Dolgin, M., Nomenclature and criteria for diagnosis of diseases of the heart and great vessels. 1994, Boston ;: Little, Brown.

73. Burnier, M., Angiotensin II type 1 receptor blockers. Circulation, 2001. 103(6): p. 904-12.

74. Cohn, J.N. and G. Tognoni, $A$ randomized trial of the angiotensin-receptor blocker valsartan in chronic heart failure. $\mathrm{N}$ Engl J Med, 2001. 345(23): $\mathrm{p}$. 1667-75. 
75. McMurray, J.J., et al., Effects of candesartan in patients with chronic heart failure and reduced left-ventricular systolic function taking angiotensinconverting-enzyme inhibitors: the CHARM-Added trial. Lancet, 2003. 362(9386): p. 767-71.

76. Harada, E., et al., Aldosterone induces angiotensin-converting-enzyme gene expression in cultured neonatal rat cardiocytes. Circulation, 2001. 104(2): p. 137-9.

77. Bauersachs, J., et al., Striking increase of natriuresis by low-dose spironolactone in congestive heart failure only in combination with $A C E$ inhibition: mechanistic evidence to support RALES. Circulation, 2000. 102(19): p. 2325-8.

78. Tang, W.H., et al., Aldosterone receptor antagonists in the medical management of chronic heart failure. Mayo Clin Proc, 2005. 80(12): p. 162330.

79. Pitt, B., et al., The effect of spironolactone on morbidity and mortality in patients with severe heart failure. Randomized Aldactone Evaluation Study Investigators. N Engl J Med, 1999. 341(10): p. 709-17.

80. Zannad, F., et al., Eplerenone in patients with systolic heart failure and mild symptoms. N Engl J Med, 2011. 364(1): p. 11-21.

81. Colucci, W.S., Molecular and cellular mechanisms of myocardial failure. Am J Cardiol, 1997. 80(11A): p. 15L-25L.

82. Haunstetter, A. and S. Izumo, Apoptosis: basic mechanisms and implications for cardiovascular disease. Circ Res, 1998. 82(11): p. 1111-29.

83. Hunter, J.J. and K.R. Chien, Signaling pathways for cardiac hypertrophy and failure. N Engl J Med, 1999. 341(17): p. 1276-83.

84. Lopez-Sendon, J., et al., Expert consensus document on beta-adrenergic receptor blockers. Eur Heart J, 2004. 25(15): p. 1341-62.

85. Ramahi, T.M., et al., Left ventricular inotropic reserve and right ventricular function predict increase of left ventricular ejection fraction after beta-blocker therapy in nonischemic cardiomyopathy. J Am Coll Cardiol, 2001. 37(3): p. 818-24.

86. Gheorghiade, M., W.S. Colucci, and K. Swedberg, Beta-blockers in chronic heart failure. Circulation, 2003. 107(12): p. 1570-5.

87. Frishman, W.H., Multifactorial actions of beta-adrenergic blocking drugs in ischemic heart disease: current concepts. Circulation, 1983. 67(6 Pt 2): p. I118.

88. Hall, S.A., et al., Time course of improvement in left ventricular function, mass and geometry in patients with congestive heart failure treated with betaadrenergic blockade. J Am Coll Cardiol, 1995. 25(5): p. 1154-61.

89. Bellenger, N.G., et al., Effects of carvedilol on left ventricular remodelling in chronic stable heart failure: a cardiovascular magnetic resonance study. Heart, 2004. 90(7): p. 760-4.

90. The Cardiac Insufficiency Bisoprolol Study II (CIBIS-II): a randomised trial. Lancet, 1999. 353(9146): p. 9-13.

91. Effect of metoprolol $C R / X L$ in chronic heart failure: Metoprolol $C R / X L$ Randomised Intervention Trial in Congestive Heart Failure (MERIT-HF). Lancet, 1999. 353(9169): p. 2001-7.

92. Packer, M., et al., Effect of carvedilol on survival in severe chronic heart failure. N Engl J Med, 2001. 344(22): p. 1651-8. 
93. Packer, M., et al., Effect of carvedilol on the morbidity of patients with severe chronic heart failure: results of the carvedilol prospective randomized cumulative survival (COPERNICUS) study. Circulation, 2002. 106(17): p. 2194-9.

94. Frishman, W.H., Carvedilol. N Engl J Med, 1998. 339(24): p. 1759-65.

95. Gilbert, E.M., et al., Comparative hemodynamic, left ventricular functional, and antiadrenergic effects of chronic treatment with metoprolol versus carvedilol in the failing heart. Circulation, 1996. 94(11): p. 2817-25.

96. Smith, T.W., Digitalis. Mechanisms of action and clinical use. N Engl J Med, 1988. 318(6): p. 358-65.

97. The effect of digoxin on mortality and morbidity in patients with heart failure. The Digitalis Investigation Group. N Engl J Med, 1997. 336(8): p. 525-33.

98. Hood, W.B., Jr., et al., Digitalis for treatment of congestive heart failure in patients in sinus rhythm: a systematic review and meta-analysis. J Card Fail, 2004. 10(2): p. 155-64.

99. Hasselblad, V., et al., Relation between dose of loop diuretics and outcomes in a heart failure population: results of the ESCAPE trial. Eur J Heart Fail, 2007. 9(10): p. 1064-9.

100. Stromberg, A., The crucial role of patient education in heart failure. Eur J Heart Fail, 2005. 7(3): p. 363-9.

101. Dickstein, K., et al., ESC Guidelines for the diagnosis and treatment of acute and chronic heart failure 2008: the Task Force for the Diagnosis and Treatment of Acute and Chronic Heart Failure 2008 of the European Society of Cardiology. Developed in collaboration with the Heart Failure Association of the ESC (HFA) and endorsed by the European Society of Intensive Care Medicine (ESICM). Eur Heart J, 2008. 29(19): p. 2388-442.

102. Stromberg, A., et al., Nurse-led heart failure clinics improve survival and selfcare behaviour in patients with heart failure: results from a prospective, randomised trial. Eur Heart J, 2003. 24(11): p. 1014-23.

103. McAlister, F.A., et al., Multidisciplinary strategies for the management of heart failure patients at high risk for admission: a systematic review of randomized trials. J Am Coll Cardiol, 2004. 44(4): p. 810-9.

104. Sudoh, T., et al., A new natriuretic peptide in porcine brain. Nature, 1988. 332(6159): p. 78-81.

105. Ogawa, Y., et al., [Molecular biology of the natriuretic peptide system]. Nihon Rinsho, 1992. 50(12): p. 2885-92.

106. Yasue, $\mathrm{H}$., et al., Localization and mechanism of secretion of B-type natriuretic peptide in comparison with those of A-type natriuretic peptide in normal subjects and patients with heart failure. Circulation, 1994. 90(1): p. 195-203.

107. Mukoyama, M., et al., Brain natriuretic peptide as a novel cardiac hormone in humans. Evidence for an exquisite dual natriuretic peptide system, atrial natriuretic peptide and brain natriuretic peptide. J Clin Invest, 1991. 87(4): p. 1402-12.

108. Hosoda, K., et al., Expression of brain natriuretic peptide gene in human heart. Production in the ventricle. Hypertension, 1991. 17(6 Pt 2): p. 1152-5.

109. Nakao, K., et al., Biosynthesis, secretion, and receptor selectivity of human brain natriuretic peptide. Can J Physiol Pharmacol, 1991. 69(10): p. 1500-6.

110. Maeda, K., et al., Plasma brain natriuretic peptide as a biochemical marker of high left ventricular end-diastolic pressure in patients with symptomatic left ventricular dysfunction. Am Heart J, 1998. 135(5 Pt 1): p. 825-32. 
111. Daniels, L.B. and A.S. Maisel, Natriuretic peptides. J Am Coll Cardiol, 2007. 50(25): p. 2357-68.

112. Maisel, A., et al., State of the art: using natriuretic peptide levels in clinical practice. Eur J Heart Fail, 2008. 10(9): p. 824-39.

113. Richards, A.M., et al., B-type natriuretic peptides and ejection fraction for prognosis after myocardial infarction. Circulation, 2003. 107(22): p. 2786-92.

114. Levin, E.R., D.G. Gardner, and W.K. Samson, Natriuretic peptides. N Engl J Med, 1998. 339(5): p. 321-8.

115. Holmes, S.J., et al., Renal, endocrine, and hemodynamic effects of human brain natriuretic peptide in normal man. J Clin Endocrinol Metab, 1993. 76(1): p. 91-6.

116. Lang, C.C., A.M. Choy, and A.D. Struthers, Atrial and brain natriuretic peptides: a dual natriuretic peptide system potentially involved in circulatory homeostasis. Clin Sci (Lond), 1992. 83(5): p. 519-27.

117. Tamura, N., et al., Two cardiac natriuretic peptide genes (atrial natriuretic peptide and brain natriuretic peptide) are organized in tandem in the mouse and human genomes. J Mol Cell Cardiol, 1996. 28(8): p. 1811-5.

118. Nakamura, S., et al., Atrial natriuretic peptide and brain natriuretic peptide coexist in the secretory granules of human cardiac myocytes. Am J Hypertens, 1991. 4(11): p. 909-12.

119. Hunt, P.J., et al., The role of the circulation in processing pro-brain natriuretic peptide (proBNP) to amino-terminal BNP and BNP-32. Peptides, 1997. 18(10): p. $1475-81$.

120. Clerico, A., et al., Cardiac endocrine function is an essential component of the homeostatic regulation network: physiological and clinical implications. Am J Physiol Heart Circ Physiol, 2006. 290(1): p. H17-29.

121. Maack, T., Receptors of atrial natriuretic factor. Annu Rev Physiol, 1992. 54: p. 11-27.

122. Jamison, R.L., S. Canaan-Kuhl, and R. Pratt, The natriuretic peptides and their receptors. Am J Kidney Dis, 1992. 20(5): p. 519-30.

123. Nakao, K., et al., Molecular biology and biochemistry of the natriuretic peptide system. II: Natriuretic peptide receptors. J Hypertens, 1992. 10(10): p. 1111-4.

124. LaPointe, M.C., Molecular regulation of the brain natriuretic peptide gene. Peptides, 2005. 26(6): p. 944-56.

125. Potter, L.R., Guanylyl cyclase structure, function and regulation. Cell Signal, 2011. 23(12): p. 1921-6.

126. Norman, J.A., et al., Degradation of brain natriuretic peptide by neutral endopeptidase: species specific sites of proteolysis determined by mass spectrometry. Biochem Biophys Res Commun, 1991. 175(1): p. 22-30.

127. McCullough, P.A. and K.R. Sandberg, B-type natriuretic peptide and renal disease. Heart Fail Rev, 2003. 8(4): p. 355-8.

128. Schou, M., et al., Kidneys extract BNP and NT-proBNP in healthy young men. J Appl Physiol (1985), 2005. 99(5): p. 1676-80.

129. Goetze, J.P., et al., BNP and N-terminal proBNP are both extracted in the normal kidney. Eur J Clin Invest, 2006. 36(1): p. 8-15.

130. McCullough, P.A., et al., B-type natriuretic peptide and renal function in the diagnosis of heart failure: an analysis from the Breathing Not Properly Multinational Study. Am J Kidney Dis, 2003. 41(3): p. 571-9.

131. Espiner, E.A., et al., Natriuretic hormones. Endocrinol Metab Clin North Am, 1995. 24(3): p. 481-509. 
132. Weber, M. and C. Hamm, Role of B-type natriuretic peptide (BNP) and NTproBNP in clinical routine. Heart, 2006. 92(6): p. 843-9.

133. Luchner, A., et al., Long-term pattern of brain natriuretic peptide and $N$ terminal pro brain natriuretic peptide and its determinants in the general population: contribution of age, gender, and cardiac and extra-cardiac factors. Eur J Heart Fail, 2013. 15(8): p. 859-67.

134. Murdoch, D.R., et al., Brain natriuretic peptide is stable in whole blood and can be measured using a simple rapid assay: implications for clinical practice. Heart, 1997. 78(6): p. 594-7.

135. Yeo, K.T., et al., Multicenter evaluation of the Roche NT-proBNP assay and comparison to the Biosite Triage BNP assay. Clin Chim Acta, 2003. 338(1-2): p. 107-15.

136. Redfield, M.M., et al., Plasma brain natriuretic peptide concentration: impact of age and gender. J Am Coll Cardiol, 2002. 40(5): p. 976-82.

137. Das, S.R., et al., Impact of body mass and body composition on circulating levels of natriuretic peptides: results from the Dallas Heart Study. Circulation, 2005. 112(14): p. 2163-8.

138. Bayes-Genis, A., et al., Effect of body mass index on diagnostic and prognostic usefulness of amino-terminal pro-brain natriuretic peptide in patients with acute dyspnea. Arch Intern Med, 2007. 167(4): p. 400-7.

139. Sarzani, R., et al., Expression of natriuretic peptide receptors in human adipose and other tissues. J Endocrinol Invest, 1996. 19(9): p. 581-5.

140. Dessi-Fulgheri, P., R. Sarzani, and A. Rappelli, The natriuretic peptide system in obesity-related hypertension: new pathophysiological aspects. J Nephrol, 1998. 11(6): p. 296-9.

141. Clerico, A., et al., The paradox of low BNP levels in obesity. Heart Fail Rev, 2012. 17(1): p. 81-96.

142. Hogenhuis, J., et al., Anaemia and renal dysfunction are independently associated with BNP and NT-proBNP levels in patients with heart failure. Eur $\mathrm{J}$ Heart Fail, 2007. 9(8): p. 787-94.

143. Bettencourt, P., et al., Prognostic information provided by serial measurements of brain natriuretic peptide in heart failure. Int $\mathrm{J}$ Cardiol, 2004. 93(1): p. 45-8.

144. Berger, R., et al., B-type natriuretic peptide predicts sudden death in patients with chronic heart failure. Circulation, 2002. 105(20): p. 2392-7.

145. Anand, I.S., et al., Changes in brain natriuretic peptide and norepinephrine over time and mortality and morbidity in the Valsartan Heart Failure Trial (ValHeFT). Circulation, 2003. 107(9): p. 1278-83.

146. Maisel, A.S., et al., Rapid measurement of B-type natriuretic peptide in the emergency diagnosis of heart failure. N Engl J Med, 2002. 347(3): p. 161-7.

147. Januzzi, J.L., Jr., et al., The N-terminal Pro-BNP investigation of dyspnea in the emergency department (PRIDE) study. Am J Cardiol, 2005. 95(8): p. 94854 .

148. Bettencourt, P., et al., $N$-terminal-pro-brain natriuretic peptide predicts outcome after hospital discharge in heart failure patients. Circulation, 2004. 110(15): p. 2168-74.

149. Logeart, D., et al., Predischarge B-type natriuretic peptide assay for identifying patients at high risk of re-admission after decompensated heart failure. J Am Coll Cardiol, 2004. 43(4): p. 635-41. 
150. Lassus, J., et al., Incremental value of biomarkers to clinical variables for mortality prediction in acutely decompensated heart failure: the Multinational Observational Cohort on Acute Heart Failure (MOCA) study. Int J Cardiol, 2013. 168(3): p. 2186-94.

151. White, M., et al., Effects of enalapril, candesartan or both on neurohumoral activation and $L V$ volumes and function in patients with heart failure not treated with a beta-blocker. Ther Adv Cardiovasc Dis, 2009. 3(2): p. 113-21.

152. Berry, C., et al., Effects of aldosterone receptor blockade in patients with mildmoderate heart failure taking a beta-blocker. Eur J Heart Fail, 2007. 9(4): p. 429-34.

153. Tsutamoto, T., et al., Effect of spironolactone on plasma brain natriuretic peptide and left ventricular remodeling in patients with congestive heart failure. J Am Coll Cardiol, 2001. 37(5): p. 1228-33.

154. Davis, M.E., et al., Introduction of metoprolol increases plasma B-type cardiac natriuretic peptides in mild, stable heart failure. Circulation, 2006. 113(7): $\mathrm{p}$. 977-85.

155. Hartmann, F., et al., NT-proBNP in severe chronic heart failure: rationale, design and preliminary results of the COPERNICUS NT-proBNP substudy. Eur J Heart Fail, 2004. 6(3): p. 343-50.

156. Stanek, B., et al., Prognostic evaluation of neurohumoral plasma levels before and during beta-blocker therapy in advanced left ventricular dysfunction. J Am Coll Cardiol, 2001. 38(2): p. 436-42.

157. Khand, A.U., et al., Carvedilol alone or in combination with digoxin for the management of atrial fibrillation in patients with heart failure? J Am Coll Cardiol, 2003. 42(11): p. 1944-51.

158. Johnson, W., et al., Neurohormonal activation rapidly decreases after intravenous therapy with diuretics and vasodilators for class IV heart failure. J Am Coll Cardiol, 2002. 39(10): p. 1623-9.

159. Fruhwald, F.M., et al., Early and sustained effects of cardiac resynchronization therapy on N-terminal pro-B-type natriuretic peptide in patients with moderate to severe heart failure and cardiac dyssynchrony. Eur Heart J, 2007. 28(13): $\mathrm{p}$. 1592-7.

160. Conraads, V.M., et al., Combined endurance/resistance training reduces NTproBNP levels in patients with chronic heart failure. Eur Heart J, 2004. 25(20): p. $1797-805$.

161. Passino, C., et al., Aerobic training decreases B-type natriuretic peptide expression and adrenergic activation in patients with heart failure. J Am Coll Cardiol, 2006. 47(9): p. 1835-9.

162. Murdoch, D.R., et al., Titration of vasodilator therapy in chronic heart failure according to plasma brain natriuretic peptide concentration: randomized comparison of the hemodynamic and neuroendocrine effects of tailored versus empirical therapy. Am Heart J, 1999. 138(6 Pt 1): p. 1126-32.

163. Troughton, R.W., et al., Treatment of heart failure guided by plasma aminoterminal brain natriuretic peptide (N-BNP) concentrations. Lancet, 2000. 355(9210): p. 1126-30.

164. Farquhar, M., Definitions of quality of life: a taxonomy. J Adv Nurs, 1995. 22(3): p. 502-8.

165. Guyatt, G.H., Measurement of health-related quality of life in heart failure. J Am Coll Cardiol, 1993. 22(4 Suppl A): p. 185A-191A. 
166. Meeberg, G.A., Quality of life: a concept analysis. J Adv Nurs, 1993. 18(1): p. 32-8.

167. World Health Organization, Constitution of the World Health Organization. Chronicle of the World Health Organizaton, vol 1. 1947, Geneva: World Health Organization.

168. Anderson, K.L. and C.S. Burckhardt, Conceptualization and measurement of quality of life as an outcome variable for health care intervention and research. J Adv Nurs, 1999. 29(2): p. 298-306.

169. Lesman-Leegte, I., et al., Quality of life and depressive symptoms in the elderly: a comparison between patients with heart failure and age- and gender-matched community controls. J Card Fail, 2009. 15(1): p. 17-23.

170. Juenger, J., et al., Health related quality of life in patients with congestive heart failure: comparison with other chronic diseases and relation to functional variables. Heart, 2002. 87(3): p. 235-41.

171. Rector, T.S., A conceptual model of quality of life in relation to heart failure. J Card Fail, 2005. 11(3): p. 173-6.

172. Johansson, P., U. Dahlstrom, and A. Brostrom, Factors and interventions influencing health-related quality of life in patients with heart failure: a review of the literature. Eur J Cardiovasc Nurs, 2006. 5(1): p. 5-15.

173. Gorkin, L., et al., Assessment of quality of life as observed from the baseline data of the Studies of Left Ventricular Dysfunction (SOLVD) trial quality-of-life substudy. Am J Cardiol, 1993. 71(12): p. 1069-73.

174. Rector, T.S. and J.N. Cohn, Assessment of patient outcome with the Minnesota Living with Heart Failure questionnaire: reliability and validity during a randomized, double-blind, placebo-controlled trial of pimobendan. Pimobendan Multicenter Research Group. Am Heart J, 1992. 124(4): p. 101725.

175. Riedinger, M.S., K.A. Dracup, and M.L. Brecht, Predictors of quality of life in women with heart failure. SOLVD Investigators. Studies of Left Ventricular Dysfunction. J Heart Lung Transplant, 2000. 19(6): p. 598-608.

176. Steptoe, A., et al., Health related quality of life and psychological wellbeing in patients with dilated cardiomyopathy. Heart, 2000. 83(6): p. 645-50.

177. Cline, C.M., et al., Health-related quality of life in elderly patients with heart failure. Scand Cardiovasc J, 1999. 33(5): p. 278-85.

178. Gill, T.M. and A.R. Feinstein, A critical appraisal of the quality of quality-of-life measurements. JAMA, 1994. 272(8): p. 619-26.

179. Ekman, I., E. Kjork, and B. Andersson, Self-assessed symptoms in chronic heart failure-important information for clinical management. Eur J Heart Fail, 2007. 9(4): p. 424-8.

180. Anker, S.D., et al., The importance of patient-reported outcomes: a call for their comprehensive integration in cardiovascular clinical trials. Eur Heart J, 2014. 35(30): p. 2001-9.

181. Rumsfeld, J.S., et al., Cardiovascular health: the importance of measuring patient-reported health status: a scientific statement from the American Heart Association. Circulation, 2013. 127(22): p. 2233-49.

182. Zannad, F., et al., Clinical outcome endpoints in heart failure trials: a European Society of Cardiology Heart Failure Association consensus document. Eur J Heart Fail, 2013. 15(10): p. 1082-94.

183. Geigle, R. and S.B. Jones, Outcomes measurement: a report from the front. Inquiry, 1990. 27(1): p. 7-13. 
184. Leplege, A. and S. Hunt, The problem of quality of life in medicine. JAMA, 1997. 278(1): p. 47-50.

185. Johansson, P., et al., Measurement of health-related quality of life in chronic heart failure, from a nursing perspective-a review of the literature. Eur $\mathrm{J}$ Cardiovasc Nurs, 2004. 3(1): p. 7-20.

186. Ware, J.E., Jr. and C.D. Sherbourne, The MOS 36-item short-form health survey (SF-36). I. Conceptual framework and item selection. Med Care, 1992. 30(6): p. 473-83.

187. Sullivan, M., J. Karlsson, and J.E. Ware, Jr., The Swedish SF-36 Health Survey--I. Evaluation of data quality, scaling assumptions, reliability and construct validity across general populations in Sweden. Soc Sci Med, 1995. 41(10): p. 1349-58.

188. Loge, J.H. and S. Kaasa, Short form 36 (SF-36) health survey: normative data from the general Norwegian population. Scand J Soc Med, 1998. 26(4): p. 250-8.

189. Sneed, N.V., et al., Evaluation of 3 quality of life measurement tools in patients with chronic heart failure. Heart Lung, 2001. 30(5): p. 332-40.

190. Karlstrom, P., et al., Brain natriuretic peptide-guided treatment does not improve morbidity and mortality in extensively treated patients with chronic heart failure: responders to treatment have a significantly better outcome. Eur J Heart Fail, 2011. 13(10): p. 1096-103.

191. Swedberg, K., et al., Guidelines for the diagnosis and treatment of chronic heart failure: executive summary (update 2005): The Task Force for the Diagnosis and Treatment of Chronic Heart Failure of the European Society of Cardiology. Eur Heart J, 2005. 26(11): p. 1115-40.

192. Vogeser, M. and K. Jacob, B-type natriuretic peptide (BNP)--validation of an immediate response assay. Clin Lab, 2001. 47(1-2): p. 29-33.

193. Morrison, L.K., et al., Utility of a rapid B-natriuretic peptide assay in differentiating congestive heart failure from lung disease in patients presenting with dyspnea. J Am Coll Cardiol, 2002. 39(2): p. 202-9.

194. BNP test for rapid quantification of B-type natriuretic peptide (BNP) (product insert)Vol. 2007/01/25. 2007, San Diego, California 92121 USA: Biosite Incorporated.

195. Ware, J.E., Jr., SF-36 health survey update. Spine (Phila Pa 1976), 2000. 25(24): p. 3130-9.

196. Sullivan, M. and J. Karlsson, SF-36 Health Survey. The Swedish manual and interpretation guide. 1994.

197. World Medical, A., World Medical Association Declaration of Helsinki: ethical principles for medical research involving human subjects. JAMA, 2013. 310(20): p. 2191-4.

198. Dixon, J.R., Jr., The International Conference on Harmonization Good Clinical Practice guideline. Qual Assur, 1998. 6(2): p. 65-74.

199. Gaggin, H.K., et al., Characterization and prediction of natriuretic peptide "nonresponse" during heart failure management: results from the ProBNP Outpatient Tailored Chronic Heart Failure (PROTECT) and the NT-proBNPAssisted Treatment to Lessen Serial Cardiac Readmissions and Death (BATTLESCARRED) study. Congest Heart Fail, 2013. 19(3): p. 135-42.

200. Sykes, E., et al., Analytical relationships among Biosite, Bayer, and Roche methods for BNP and NT-proBNP. Am J Clin Pathol, 2005. 123(4): p. 584-90. 
201. Shah, M.R., et al., The STARBRITE Trial: A Randomized, Pilot Study of BType Natriuretic Peptide-Guided Therapy in Patients With Advanced Heart Failure. J Card Fail, 2011. 17(8): p. 613-21.

202. Eurlings, L.W., et al., Management of chronic heart failure guided by individual $N$-terminal pro-B-type natriuretic peptide targets: results of the PRIMA (Can PRo-brain-natriuretic peptide guided therapy of chronic heart failure IMprove heart fAilure morbidity and mortality?) study. J Am Coll Cardiol, 2010. 56(25): p. 2090-100.

203. Lainchbury, J.G., et al., N-terminal pro-B-type natriuretic peptide-guided treatment for chronic heart failure: results from the BATTLESCARRED (NTproBNP-Assisted Treatment To Lessen Serial Cardiac Readmissions and Death) trial. J Am Coll Cardiol, 2009. 55(1): p. 53-60.

204. Pfisterer, M., et al., BNP-guided vs symptom-guided heart failure therapy: the Trial of Intensified vs Standard Medical Therapy in Elderly Patients With Congestive Heart Failure (TIME-CHF) randomized trial. Jama, 2009. 301(4): p. 383-92.

205. Persson, H., et al., Improved pharmacological therapy of chronic heart failure in primary care: a randomized Study of NT-proBNP Guided Management of Heart Failure--SIGNAL-HF (Swedish Intervention study--Guidelines and NTproBNP AnaLysis in Heart Failure). Eur J Heart Fail, 2010. 12(12): p. 1300-8.

206. Anguita, M., et al., [Usefulness of brain natriuretic peptide levels, as compared with usual clinical control, for the treatment monitoring of patients with heart failure]. Med Clin (Barc), 2010. 135(10): p. 435-40.

207. Berger, R., et al., $N$-terminal pro-B-type natriuretic peptide-guided, intensive patient management in addition to multidisciplinary care in chronic heart failure a 3-arm, prospective, randomized pilot study. J Am Coll Cardiol, 2010. 55(7): p. $645-53$.

208. Jourdain, P., et al., Plasma brain natriuretic peptide-guided therapy to improve outcome in heart failure: the STARS-BNP Multicenter Study. J Am Coll Cardiol, 2007. 49(16): p. 1733-9.

209. Januzzi, J.L., Jr., et al., Use of amino-terminal pro-B-type natriuretic Peptide to guide outpatient therapy of patients with chronic left ventricular systolic dysfunction. J Am Coll Cardiol, 2011. 58(18): p. 1881-9.

210. Troughton, R.W., et al., Effect of B-type natriuretic peptide-guided treatment of chronic heart failure on total mortality and hospitalization: an individual patient meta-analysis. Eur Heart J, 2014. 35(23): p. 1559-67.

211. Hogenhuis, J., et al., Influence of age on natriuretic peptides in patients with chronic heart failure: a comparison between ANP/NT-ANP and BNP/NTproBNP. Eur J Heart Fail, 2005. 7(1): p. 81-6.

212. de la Porte, P.W., et al., Added value of a physician-and-nurse-directed heart failure clinic: results from the Deventer-Alkmaar heart failure study. Heart, 2007. 93(7): p. 819-25.

213. McMurray, J.J., et al., Angiotensin-neprilysin inhibition versus enalapril in heart failure. N Engl J Med, 2014. 371(11): p. 993-1004.

214. Cohen-Solal, A., et al., Lowered B-type natriuretic peptide in response to levosimendan or dobutamine treatment is associated with improved survival in patients with severe acutely decompensated heart failure. J Am Coll Cardiol, 2009. 53(25): p. 2343-8.

215. Wang, T.J., et al., Plasma natriuretic peptide levels and the risk of cardiovascular events and death. N Engl J Med, 2004. 350(7): p. 655-63. 
216. Goetze, J.P., et al., Plasma chromogranin A is a marker of death in elderly patients presenting with symptoms of heart failure. Endocr Connect, 2014. 3(1): p. 47-56.

217. Alehagen, U., et al., Association of copeptin and N-terminal proBNP concentrations with risk of cardiovascular death in older patients with symptoms of heart failure. JAMA, 2011. 305(20): p. 2088-95.

218. Alehagen, U., et al., Pro-A-type natriuretic peptide, proadrenomedullin, and $\mathrm{N}$ terminal pro-B-type natriuretic peptide used in a multimarker strategy in primary health care in risk assessment of patients with symptoms of heart failure. J Card Fail, 2013. 19(1): p. 31-9.

219. Bayes-Genis, A., et al., Head-to-head comparison of 2 myocardial fibrosis biomarkers for long-term heart failure risk stratification: ST2 versus galectin-3. J Am Coll Cardiol, 2014. 63(2): p. 158-66.

220. Bhardwaj, A., et al., Quality of life and chronic heart failure therapy guided by natriuretic peptides: results from the ProBNP Outpatient Tailored Chronic Heart Failure Therapy (PROTECT) study. Am Heart J, 2012. 164(5): p. 793799 e1.

221. Stull, D.E., L.A. Clough, and D. Van Dussen, Self-report quality of life as a predictor of hospitalization for patients with $L V$ dysfunction: a life course approach. Res Nurs Health, 2001. 24(6): p. 460-9.

222. Ekman, I., B. Fagerberg, and B. Lundman, Health-related quality of life and sense of coherence among elderly patients with severe chronic heart failure in comparison with healthy controls. Heart Lung, 2002. 31(2): p. 94-101.

223. Sullivan, M. and J. Karlsson, The Swedish SF-36 Health Survey III. Evaluation of criterion-based validity: results from normative population. J Clin Epidemiol, 1998. 51(11): p. 1105-13.

224. Ancheta, I.B., et al., The impact of B-type natriuretic peptide, New York Heart Association classification and depression on quality of life in nonhospitalized heart failure patients. Prog Cardiovasc Nurs, 2009. 24(4): p. 124-30.

225. Grady, K.L., et al., Predictors of quality of life in patients with advanced heart failure awaiting transplantation. J Heart Lung Transplant, 1995. 14(1 Pt 1): p. 2-10.

226. Agvall, B., U. Alehagen, and U. Dahlstrom, The benefits of using a heart failure management programme in Swedish primary healthcare. Eur J Heart Fail, 2013. 15(2): p. 228-36.

227. Benatar, D., et al., Outcomes of chronic heart failure. Arch Intern Med, 2003. 163(3): p. 347-52.

228. Holmstrom, A., et al., Increased comorbidities in heart failure patients $>/=85$ years but declined from $>90$ years: data from the Swedish Heart Failure Registry. Int J Cardiol, 2013. 167(6): p. 2747-52. 



\section{Papers}

The articles associated with this thesis have been removed for copyright reasons. For more details about these see:

http://urn.kb.se/resolve?urn=urn:nbn:se:liu:diva-124560 